MacKinnon D, Dawley S, Steen M, Menzel MP, Karlsen A, Sommer P, Hansen GH, Normann HE. Path creation, global production networks and regional development: a comparative international analysis of the offshore wind sector. Progress in Planning (2018)

DOI link

https://doi.org/10.1016/i.progress.2018.01.001

ePrints link

http://eprint.ncl.ac.uk/pub details2.aspx?pub id=245927

Date deposited

$14 / 02 / 2018$

Embargo release date

$10 / 08 / 2019$

Copyright

(C) 2018. This manuscript version is made available under the CC-BY-NC-ND 4.0 license

\title{
Licence
}

This work is licensed under a

Creative Commons Attribution-NonCommercial-NoDerivatives 4.0 International licence

$$
\text { (6) }(\mathbb{D} \Theta \Theta
$$




\title{
Path creation, global production networks and regional development: a comparative international analysis of the offshore wind sector
}

\author{
\# Danny MacKinnona, Stuart Dawleya, Markus Steenb, c, Max-Peter \\ Menzel d, + Asbjørn Karlsen b, Pascal Sommer d, ^, Gard Hopsdal Hansen e, \\ Håkon Endresen Normann f
}

\section{Forthcoming in Progress in Planning}

https://www.journals.elsevier.com/progress-in-planning

Please note: Changes made as a result of publishing processes such as copy-editing, formatting and page numbers may not be reflected in this version. For the definitive version of this publication, please refer to the published source. You are advised to consult the publisher's version if you wish to cite this paper.

a Centre for Urban and Regional Development Studies (CURDS), School of Geography, Sociology \& Politics, Newcastle University, Newcastle upon Tyne, NE1 7RU.

b Norwegian University of Science and Technology, Department of Geography, NO-7491

Trondheim, Norway

c SINTEF Technology \& Society, Department of Industrial Management, NO-7465

Trondheim, Norway

d University of Hamburg, Institute of Geography, Bundesstraße 55, 20146

Hamburg

e Norwegian University of Science and Technology, Centre for Sustainable Energy Studies, NO-7491

Trondheim, Norway

f University of Oslo, TIK Centre for Technology, Innovation and Culture, 0317 Oslo, Norway

+ Present address: University of Bayreuth, Institute of Geography, Universitätsstraße 30, 95447

Bayreuth

^ Present address: 8.2 Consulting AG, Burchardstraße 17, 20095 Hamburg

\# Corresponding author: Prof Danny MacKinnon, Centre for Urban and Regional Development Studies (CURDS), School of Geography, Sociology \& Politics, Newcastle University, Newcastle upon Tyne, NE1 7RU. Tel: 0191-2088604, danny.mackinnon@ncl.ac.uk 


\section{Abstract}

The question of how regions and nations develop new sources of industrial growth is of recurring interest in economic geography and planning studies. From an evolutionary economic geography (EEG) perspective, new growth paths emerge out of existing economic activities and their associated assets and conditions. In response to the micro-economic and endogenous focus of much EEG research, this paper utilises a broader evolutionary perspective on path creation which stresses the dynamic interplay between four sets of factors: regional assets; key economic and organisational actors; mechanisms of path creation; and multi-scalar institutional environments and policy initiatives. Reflecting the importance of extra-regional networks and institutions, this framework is also informed by the Global Production Networks (GPN) approach, which highlights the process of strategic coupling between firms and regions and its political and institutional mediation by state institutions at different spatial scales. We deploy this framework to investigate regional path creation in the context of renewable energy technologies, focusing specifically on the offshore wind industry. We adopt a comparative cross-national approach, examining the evolution of offshore wind in Germany, the UK and Norway. Of the three cases, Germany has developed the most deep-rooted and holistic path to date, characterised by leading roles in both deployment and manufacturing. By contrast, path creation in the UK and Norway has evolved in more partial and selective ways. The UK's growth path is developing in a relatively shallow manner, based largely upon deployment and 'outside in' investment, whilst Norway's path is emerging in an exogenous, 'inside-out' fashion around a fairly confined set of actors and deployment and supply functions. In conclusion, the paper emphasises the important role of national states in orchestrating the strategic coupling of regional and national assets to particular mechanisms of path creation.

\section{Keywords}

Evolutionary economic geography; path creation; national states; global production networks; offshore wind; international comparative analysis 


\section{Path creation, global production networks and regional development: a comparative international analysis of the offshore wind sector}

\section{Introduction}

The question of how regions and nations develop new sources of industrial growth is of recurring interest in economic geography and planning studies (Chapman and Walker 1991; Storper and Walker 1989). This has been often understood in terms of the emergence of new growth sectors and clusters driven by entrepreneurialism, spinoffs from established firms and new market opportunities (Dahl et al. 2010). Conventionally, new forms of industrial growth were assumed to largely take place in established industrial centres with dense business networks, pools of specialised labour and a range of research and development facilities (Chapman and Walker 1991: 154-5). In the 1980s and 1990s, much of this research focused on high-technology industries such as advanced electronics, computer equipment and aerospace in 'new industrial spaces' in North America and Western Europe (see Scott 1988). More recent work on the emergence of new industries and clusters has largely remained concerned with growth regions more broadly defined (Kenney and von Burg 2001; Mayer et al. 2011), although other studies are starting to focus attention on old industrial regions, where the challenges of industrial renewal and growth are rendered particularly acute by the legacies of deindustrialisation (Dawley 2014; Isaksen 2014). As indicated by the recent revival of interest in industrial strategy, the identification of new sources of industrial growth is also an important policy question (Bailey et al. 2015; Chang et al. 2013).

Research on industry growth has gained renewed momentum in recent years, partly through the development of evolutionary economic geography (EEG) as a distinct perspective (see Boschma and Martin 2007). Accordingly, the question has been redefined as one of path 
creation, referring to how new growth trajectories and dynamics emerge and develop in cities and regions (Dawley 2014; Simmie 2012). The adoption of an EEG perspective places particular emphasis on how new growth paths emerge out of existing economic activities and their associated assets and conditions (Isaksen 2014). The question of path creation has been opened up by a recasting of the 'canonical' model of path dependence in favour of a broader 'path as process' approach (Martin and Sunley 2006) that incorporates path creation and path destruction in addition to a more open notion of path dependence.

Much EEG work on path creation has taken a micro-economic approach that views firms and entrepreneurs as the main agents of path creation, informed by the experiences of dynamic growth regions such as Cambridge, England and Silicon Valley, California (Morgan 2013; Simmie et al. 2008). Regional conditions in terms of innovation systems, knowledge networks and the legacies of previous industries have been the main focus of attention (Fornahl et al. 2012), although some accounts have highlighted the role of wider extraregional factors, particularly national policy frameworks and institutional environments (Dawley 2014; Simmie 2012). Yet this dimension remains relatively underplayed, both in relation to national and supra-national political and institutional frameworks and transnational production networks.

This paper aims to contribute to the burgeoning path creation research agenda by developing a fuller understanding of the process of path creation in regions. It addresses the central research question of identifying and explaining the key actors, mechanisms and institutions behind the formation of new industrial growth paths at the regional and national scales of analysis. The paper utilises a broader evolutionary perspective on path creation in regions which stresses the dynamic interplay between four sets of factors: regional assets; key 
economic and organisational actors; mechanisms of path creation; and multi-scalar institutional environments and policy initiatives. Reflecting the importance of transplantation as a key mechanism of path creation in the offshore wind sector (see below) and the need to relate regional level influences to extra-regional firm networks, our analysis draws upon the Global Production Networks (GPN) approach (Coe et al. 2004; Yeung and Coe 2015). This provides a dynamic framework for grasping the multiple and bi-directional relations between firms and regions and their political and institutional mediation by state institutions at different spatial scales.

We deploy this framework to investigate regional path creation in the context of renewable energy technologies (RETs) which have expanded substantially in recent years in the face of concerns about climate change (Essletzbichler 2012). For the most part, RETs have been price uncompetitive with established fossil fuel technologies, requiring state support. This has meant that regional path creation in RET sectors is crucially dependent on the alignment of regional, national and supra-national policy agendas.

More specifically, we focus on the offshore wind industry which has been identified as a key growth sector by policy-makers in several countries in recent years (Dawley et al 2015; Fornahl et al. 2012). Compared to onshore wind, offshore wind development is more complex in nature, occurring in technologically and operationally challenging maritime environments and requiring large-scale, up-front investment before any returns are generated (Lema et al. 2011). As such, the sector is dominated by large corporations, particularly energy utilities and turbine manufacturers, underlining the utility of a GPN perspective for analysing how regional path creation is shaped by this firm-state nexus. 
We adopt a comparative cross-national approach, examining path creation in offshore wind in three European countries: Germany, the UK and Norway. In particular, we explore the contrasting national and regional trajectories emerging through attempts to harness offshore wind resources to create new paths of industrial growth and support energy transition. In the case of the UK, whilst the scale and scope of its shallow territorial waters has helped create the world's largest offshore wind market, the development of an allied path of industrial growth remains weaker. In contrast, Germany has developed into Europe's second largest offshore wind market whilst also creating a world-leading industrial growth path. Finally, whilst the exploitation of Norway's marine resources has been restricted by its abundance of hydropower resources and the technological challenge of negotiating its deep seas, niche growth paths are nonetheless emerging through industrial diversification for export markets (Steen and Hansen 2014).

Our approach offers an important and novel contribution to recent debates about 'doing' evolutionary research within the relatively youthful field of EEG (Pike et al 2016). Our crossnational framework seeks to strengthen comparison within evolutionary studies and address the tendency of existing work to focus on particular spatial contexts (e.g. regions) in singlecountry settings (Boschma 2017). We draw on McMichael's (2000) notion of 'incorporated comparison' as part of a more relational understanding of how the varying processes of path creation in our cases studies are positioned within the international offshore wind industry. In so doing, our approach involved 'deep contextualisation' methods (Martin and Sunley 2015) to handle both agency and context within, and across, the three cases. This was designed to uncover the "deep-seated as well as wider relations, positions and contexts" shaping each growth path (Pike et al 2016 p.132). 
Contributing to an evolutionary perspective, we adopted a longitudinal research design to integrate several related research projects conducted as part of an ongoing programme of research between our three national research teams (see Dawley 2014; Steen and Hansen 2014). Practically, this involved a coordinated mixed methods approach across the three cases, comprising over 170 semi-structured interviews with policy-makers and industry personnel, covering regional agencies, national and supra-national government bodies, representatives of industry associations and firm managers and directors, alongside the analysis of policy documents, particularly policy statements, strategies, initiatives and reports. In addition, our collective immersion over a sustained period, in excess of 10 years for each research team, in the case study contexts provided a rich set of contact networks, allowing the informed selection of key informants alongside forms of nonparticipant observation (e.g. policy events; trade fairs etc.) (Karlsen 2018). Within, and across, each case our mixed methods were used to identify and explore key historical episodes of path activity, ranging from pre-formation (the historical antecedents) to path development trajectories, as analytical lenses within which to uncover the sets of actors involved, their internal and external relations, and the range of mediating factors and influences.

The remainder of the paper is structured in seven main sections. The next section elaborates our analytical framework based on the development of a broader evolutionary perspective on path creation. This is followed by a review of the growth and organisation of the offshore wind industry in global terms. The paper then turns to the three national case studies, dealing with Germany, the UK and Norway in turn. A subsequent discussion section draws out the key commonalities and differences across these case studies. Finally, a brief conclusion draws out the broader implications of the analysis. 


\section{Understanding Path Creation: an Analytical Framework}

The evolutionary concept of path creation is based on the notion that regional growth paths "do not start from scratch but are strongly rooted with the historical economic structure of a region" (Neffke et al. 2011: 261). More broadly, Isaksen (2014) defines path creation as one of four possible development paths of regional economies. First, path extension involves the reproduction of existing economic trajectories, based on incremental innovation within preexisting technological paradigms and involving continual adjustment to changing external conditions. Second, path exhaustion refers to the erosion and decline of established paths as firms become locked in to established technologies and practices and are unable to adapt to change. Third, path renewal occurs when firms and other economic actors adapt by moving into technologically related sectors through a process of regional branching involving diversification and the redeployment of existing assets and competencies. Fourth, path creation refers to the emergence of new development trajectories in a region based upon the growth of new industrial sectors or new products, techniques and forms of organisation. It may occur through inward investment, the sectoral diversification of firms through path branching or the establishment of new firms and spin-offs.

At the same time, path creation can be seen as a distinct stage within a broader process of regional path-dependent evolution. Here, Martin (2010) has usefully identified different phases of this evolutionary process (see Figure 1). The first is comprised of a preformation phase dominated by pre-existing economic and technological conditions and the resources, competences, skills and experiences inherited from previous forms of economic development. This is succeeded by a path creation phase where there is experimentation but also competition between different economic agents which leads to the emergence of a new path. 
Path creation subsequently gives way to a path development phase based upon local increasing returns and externalities. Established pathways are subject to subsequent divergence, towards either a 'stable state' where increasing technological reinforcement and institutional sclerosis leads to stasis or the successful modernisation and renewal of the regional economy (see Grabher 1993).

Figure 1. Towards an alternative model of local industrial evolution (Source: Martin 2010: 21)

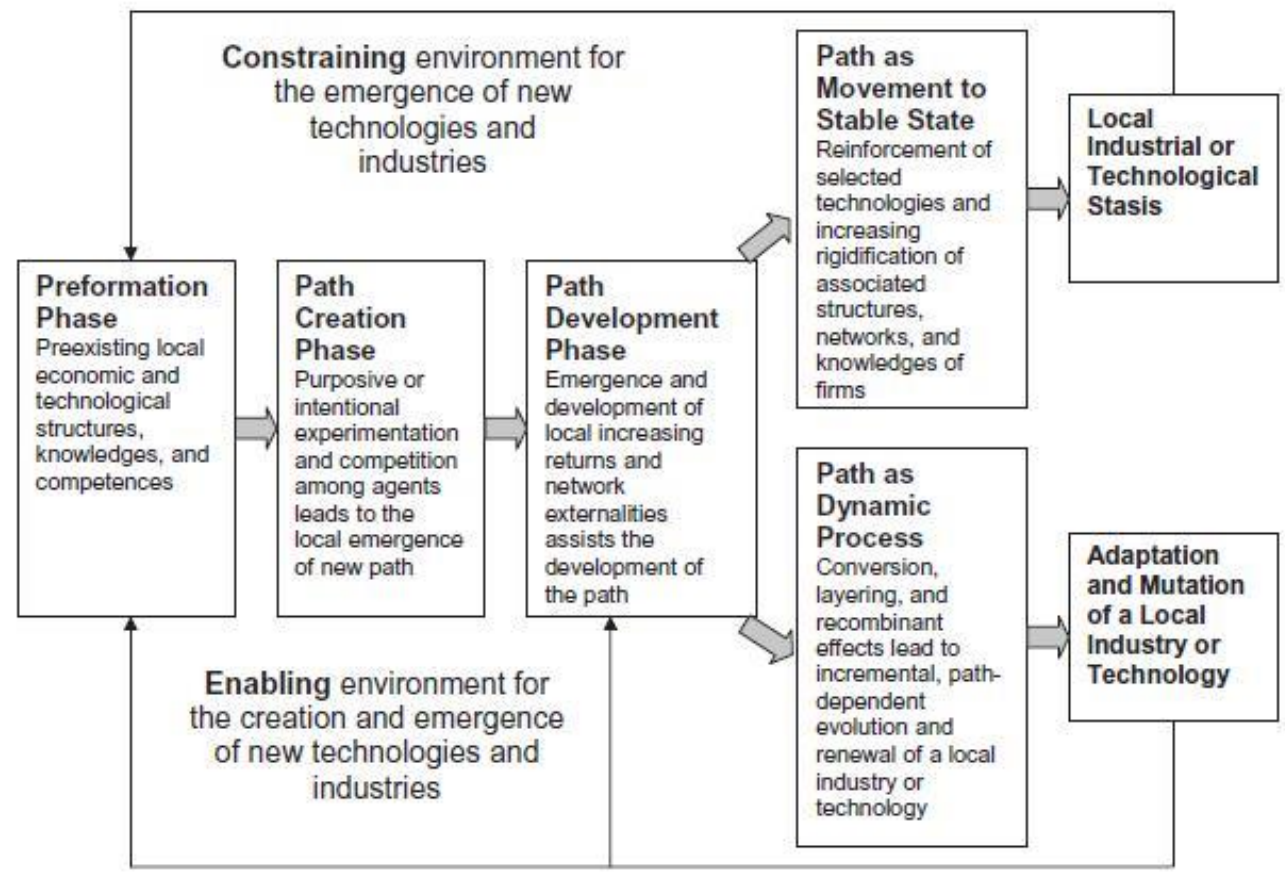

This provides a useful framework for understanding the evolution of regional economies, but tells us little about the nature and operation of path creation processes. Path creation is largely represented as a latent element of path dependence, requiring further research into the operation of its underlying actors, mechanisms and outcomes (Dawley 2014). This paper is designed to contribute to this emerging research agenda, arguing that path creation must not only be analysed in relation to indigenous factors within regions, but also extra-regional relations and actors (Binz et al. 2016). 
In the remainder of this section, we present our evolutionary approach. It is important to clarify at this point that we do not see path creation as a theory which can itself be used to explain the emergence of new industrial trajectories. Path creation is instead the key research object or phenomenon in question which must itself be explained, informed by the key elements of our framework. As such, path creation is the explanandum (that which is to be explained) rather than the explanas (that which explains) in our analysis (Painter and Goodwin 1995, p. 338).

Path creation, we argue, depends upon the articulation of the four elements of our framework - regional assets; key actors; mechanisms of path creation; and multi-scalar institutional environments and policy initiatives - in a region at a particular point in time, stimulating a distinct trajectory of development as a new industry emerges and gains momentum and critical mass. Before outlining each of the elements, we highlight the key interactions between them (Figure 2). Operating in the context of particular institutional environments, key economic and organisational actors seek to harness and valorise identified regional assets, matching or 'coupling' these assets to specific mechanisms of path creation such as diversification, indigenous path creation and transplantation. It is this process of matching or strategic coupling between regional assets and mechanisms that defines the emerging path and provides the critical mass and forward momentum to propel the process of growth. The concept of strategic coupling is adapted from GPN research, but broadened beyond FDI and transplantation to incorporate diversification and indigenous creation as the other key mechanisms (see below). 
Figure 2 A conceptual framework for assessing regional path creation

\section{Multi-scalar Institutional Environments}

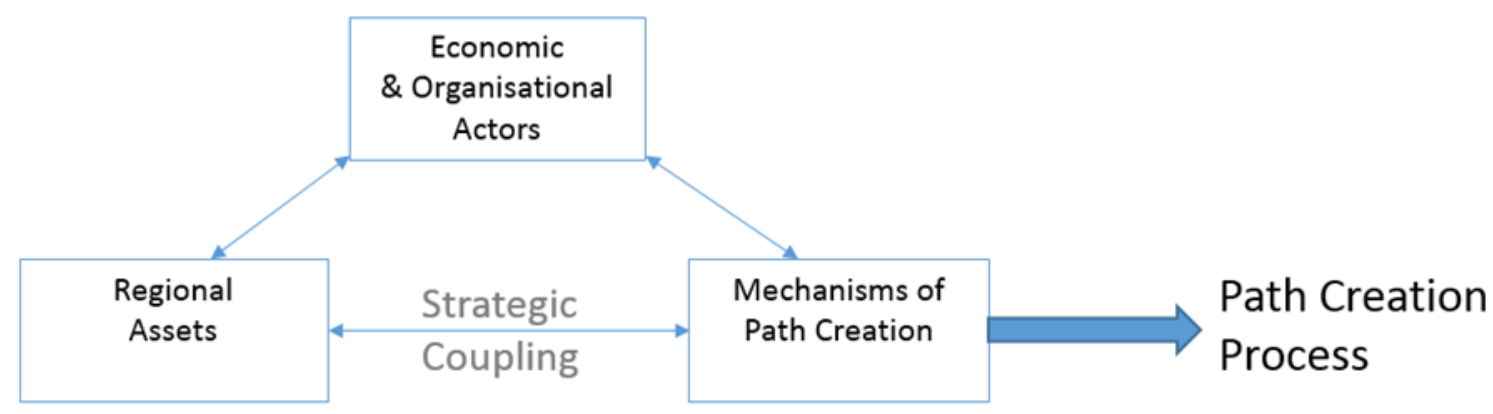

\section{Multi-scalar Institutional Environments}

Informed by the GPN approach, we view regional assets as an important basis for path creation in regions. In this sense, path creation is analogous to the process of value creation in GPN research, whereby regional assets are a necessary pre-condition for regional development (Coe and Yeung 2015). Our approach to regional assets identifies five key domains: natural assets covering resources; infrastructural and material assets; industrial assets (covering technological and firm-based competences); human assets (labour skills, costs and knowledge); and institutional assets (covering the endowment of rules and norms; and the forms and roles of institutional actors) (see Maskell and Malmberg 1999). They are likely to reflect previous forms and patterns of economic development in a region to a considerable extent, representing the preformation phase of path development (Martin 2010).

Our incorporation of natural assets is informed by Bridge's (2008) work on extractive industries which recognises that natural resource endowments may be a key source of 
regional advantage. Similar to the ways in which extractive industries (e.g. oil) are driven by a 'resource imperative' to seek out and exploit new reserves, the upstream elements of renewable energy industries also seek out geographical variations in the quality and capacity of renewable resources and asset bases (e.g. wind speeds; tidal ranges etc.). The incorporation of natural resources into our notion of regional assets assists in broadening the scope of analysis beyond firms and entrepreneurs. As Bridge (2008) observes, natural resources (e.g. minerals; sites for marine-based renewables) are generally the reserved property of the state and it therefore becomes the key actor in setting and mediating the terms by which other parties may seek to access and valorise these resources.

Regional assets can only foster successful path creation if they are identified, harnessed and valorised by economic actors and institutions through specific economic development activities and initiatives (for example: research and development ( $R$ and $D$ ) initiatives, firm start-ups and spin-offs and inward investment promotion) (see Coe et al. 2004). This connects to recent work on path creation that stresses the importance of strategic agency and 'mindful deviation' from existing paths (Garud and Karnoe 2003; Simmie 2012). Most of this work identifies firms and entrepreneurs as the primary actors behind path creation in terms of the identification of market opportunities, establishment of spin-off firms and introduction of new products and processes. This reflects the micro-economic orientation of key strands of research in EEG, emphasising organisational routines, entrepreneurial search processes and innovation networks (Boschma and Franken 2006). Such an understanding of path creation is informed by a number of influential studies of dynamic, growth regions which highlight the importance of inter-related processes of spin-off, innovation and learning involving leading firms, entrepreneurs, universities and research institutes (Klepper 2007; Simmie et al. 2008). At the same time, work on the Danish wind industry has emphasised the shaping role of 
pioneer innovators, engineers and farmers located in rural areas who built and used turbines and came together in networks and cooperatives, although policy and financial support from the state also played a crucial role (Simmie 2012).

In addition, while path creation is often assumed to be a spontaneous, market-led process, the role of states is often crucial (Dawley et al., 2015), particularly in emerging technologies such as offshore wind which have not been price competitive in established markets

(Essletzbichler 2012). The role of states can be understood in relation to three types of policy: horizontal, vertical and spatial. Horizontal policies incorporate a range of approaches and instruments by which states seek to construct and regulate markets with the aim of fostering a favourable and competitive business environment for firms, incorporating spheres such as monetary and fiscal policy, education, infrastructure and R and D (Chang et al. 2013). They are likely to be particularly significant for emerging technologies and industries such as biotechnology and renewable energy, often requiring the introduction of price supports and subsidies (Essletzbichler 2012). Second, vertical policies are selective and sector-based, involving the targeting of particular industries (Chang et al 2013). The development of local industrial capacity through the strengthening of supply chains for insertion into global production networks is often an important element of vertical policy (Smith 2015). Third, states also support path creation through spatial policies that aim to promote local and regional development in particular places. Here, the spatial planning system plays an important role in co-ordinating and regulating development according to sometimes conflicting societal goals and norms (Nadin and Stead 2008).

Recent research has also drawn attention to the role of different mechanisms of path creation. In particular, Martin and Sunley (2006) identify five regional 'de-locking' mechanisms: 
indigenous path creation, based upon the exploitation of new technological paradigms; heterogeneity among agents, technologies, institutions and social networks which fosters variety and innovation; transplantation through the importation and diffusion of new technologies, firms or industries; diversification into related industrial sectors; and, the upgrading of a region's industrial base. The development of such mechanisms can be seen as playing a crucial role in the transition from the pre-formation phase to path creation proper and subsequent path development (Martin 2010) by imparting sufficient forward momentum to foster self-reinforcing growth. Their identification at an abstract level provides an important point of departure for empirical research.

Of the mechanisms of path creation identified by Martin and Sunley (2006), transplantation and diversification assume particular importance in the offshore wind sector, with indigenous creation also of some interest. We argue that the increasing globalisation of production requires a broader understanding of transplantation than merely the attraction of Foreign Direct Investment (FDI) to a host region, given that this can also stimulate growth paths in the origin, or home, regions of firms that are expanding outwards into overseas markets (Dicken 2015). This directs our attention to the GPN approach which provides a broad relational framework for the analysis of the relationships between regions and global production networks. The latter can be defined as "organisational arrangement[s] comprising interconnected economic and noneconomic actors coordinated by a global lead firm and producing goods and services across multiple geographic locations for worldwide markets" (Yeung and Coe 2015: 4). Recent elaborations of the GPN approach help to recast it as a broader framework for investigating the multiple relations between firms and regions (Coe and Yeung 2015). Rather than seeing these relations merely in terms of conventional inward investment whereby regional actors seek to attract external firms into their region ('outside- 
in'), they are two-way in orientation, also incorporating the expansion of regionally-based firms through outwards investment in other regions ('inside-out').

From a GPN perspective, regional development is the result of the 'strategic coupling' between global production networks and regional assets (Coe et al. 2004). According to Yeung (2009: 213), "strategic coupling refers to the dynamic processes through which actors in cities and/or regions coordinate, mediate, and arbitrage strategic interests between local actors and their counterparts in the global economy". In practice, this often focuses attention on the relationship between regions and Trans-National Corporations (TNCs), often described as 'lead' firms in global production networks (Coe et al. 2008). Such lead firms are key actors in path creation, not least in terms of providing material and organisational linkages between growth processes taking place in different countries and regions. The role of regional actors is to foster strategic coupling by shaping and moulding regional assets to fit the needs of these lead firms in global production networks.

Diversification as the second key mechanism of path creation emphasised in this paper has been the principal focus of attention in the EEG literature on relatedness and path creation (Boschma 2017). Four sub-mechanisms of regional branching have been identified: entrepreneurial activities such as spin-offs and start-ups; firm diversification; labour mobility between firms and sectors; and social networking between agents (Boschma and Frenken 2011). In the EEG literature, diversification is often described as path branching, emphasising how regions move into new industrial sectors and technologies that are related to existing activities, based on the harnessing of knowledge spillovers and technological capabilities (Neffke et al. 2011; Tanner 2014). Technological forms of branching have been emphasised in empirical research with one influential study, based on Swedish data, explaining that 
industries are more likely to grow in a region if they were technologically related to preexisting industries in that region (Neffke et al. 2011). The processes by which branching actually occurs at the firm level have received less attention in EEG, however, particularly in terms of how firms and other organisations identify opportunities and transfer their knowledge and competencies into new sectors and markets (Cooke 2012).

In addition, indigenous creation may also be of interest in the offshore wind sector, involving the exploitation of emerging wind technologies by various inventors, 'hobbyists' and entrepreneurs. This dynamic was certainly evident in the pioneering Danish wind sector where a group of pioneering innovators played a key role in developing early turbines, building links with farmers and rural co-operatives as key users (Simmie 2012). Key innovators and investors also played a similarly critical role in the development of the wind turbine industry in Germany (Simmie et al. 2014). Such indigenous creation faces much greater challenges in the offshore sector, however, given its greater scale and capitalintensity, particularly in terms of the need for large up-front investment. Research and development activities, often involving the development and testing or prototypes, play a key role, but are often undertaken by larger firms and research institutes and may be reliant on exogenous funding sources (Dawley 2014; Goddard et al. 2012).

The fourth element in our analytical framework concerns the role of multi-scalar institutional environments in shaping path creation. By institutional environments, we are referring to the broader structures of formal and informal rules, conventions and practices that shape economic development, spanning both 'hard' organisational structures and regulations and 'soft' norms and habits (Martin, 2000). We view institutional environments as multi-scalar in nature, incorporating national, supra-national and industry-wide rules and norms in addition 
to local and regional arrangements. It is important to positon the different path creation actors identified above (for example entrepreneurs and state actors) within their institutional environments rather than viewing actors and institutional environments as separate. This statement is informed by the established distinction between institutional environments as broader sets of rules and norms and institutional arrangements as specific organisations (Martin 2000).

Informed by the Varieties of Capitalism (VoC) literature (Hall and Soskice 2001), we are particularly concerned with the role of national states in shaping path creation processes. Here, the VoC approach draws the well-known distinction between two ideal types: liberal market economies (LMEs) and co-ordinated market economies (CMEs), based upon the level of coordination between firms and associated economic institutions (Peck and Theodore 2007). LMEs are thought to have a comparative advantage in fostering radical forms of pathbreaking innovation, whilst innovation in CMEs tends to be more continuous and incremental in nature (Cetkovic et al. 2016). Based upon the work of Schmidt (2005), Cetkovic et al. (2016) introduce a further distinction between 'simple' and 'compound' LMEs and CMEs to take account of the multi-scalar character of institutional environments (cf. Schroder and Voelzkow 2016), which is ignored by the nationally-fixated VoC approach (Peck and Theodore 2007). The state structure is centralised and concentrated in a single authority in 'simple' systems, whereas 'compound' ones feature multiple authorities, such as in federal polities. The role of supra-national organisations such as the EU adds an important additional multi-scalar dimension, influencing regional path creation through a range of interventions, including the establishment of overarching targets and policy frameworks (Essletzbichler 2012). 
Martin (2010) draws an important distinction between enabling and constraining institutional environments for regional path creation as part of his alternative model of local industrial evolution (Figure 1). Here, the existence of an enabling institutional environment is associated with the successful adaptation and renewal of a local industry or technology over time and a constraining institutional environment is equated with stasis and lock-in. In the former case, institutions would seem to co-evolve with the local industries or technologies in question, whereas in the latter case the absence of such local institutional evolution is itself a source of lock-in and decline. Martin does not state at which scales these institutional effects operate, although the model generally privileges the local and regional scales. Our approach not only adopts a multi-scalar approach to institutional environments, but also views them in dynamic terms, opening up the question of whether constraining environments can become enabling and vice-versa.

This section has set out a conceptual framework for examining path creation in offshore wind, comprised of four elements: regional assets, the key actors that shape path creation, the main mechanisms of path creation, and multi-scalar institutional environments. As indicated above, the process of path creation requires the forging of developmental and harmonious relations between the elements of our framework, involving actors, operating within distinct institutional environments, strategically coupling regional assets to particular mechanisms of path creation (Figure 2). Reflecting our broadening of the term beyond FDI and transplantation to also incorporate diversification and indigenous path creation, the concept of strategic coupling can also be used to characterise the nature of the regional growth paths created. Drawing upon MacKinnon (2012), Coe and Yeung (2015) identify three modes of strategic coupling which shape the qualitative characteristics of the paths being created. The first concerns an indigenous or organic form of coupling whereby leading firms develop out 
of distinctive regional assets, reflecting previous rounds of path creation based upon entrepreneurship and innovation. This form of coupling is often found in dynamic growth regions like Silicon Valley and Cambridge (UK) which tend to retain headquarters and other high-level functions and become innovation hubs. Functional coupling represents a second form of coupling whereby distinctive regional assets are harnessed to generate sustained economic development, involving the growth of local firms and/or the attraction of external investors. They typically offer a considerable degree of value capture for the regional economy in question, but lower levels of autonomy and control than organic forms of coupling. Third, structural coupling is characterised by unequal power relations between lead firms and regions, typically reflecting the structural power of TNCs attracted by generic regional assets such as labour surpluses and available industrial sites. This form of coupling often corresponds to the far more limited and truncated form of path creation associated with assembly platforms for export. 


\section{Growth and Organisation of the Offshore Wind Industry}

The growth of offshore wind has occurred as part of the expansion of renewable energy technologies in recent years, driven by a range of interrelated factors including technological innovation, climate change targets and energy security (Essletzbichler 2012; Kern et al. 2014). In particular, in an increasingly carbon constrained world, renewable energy is viewed as integral in achieving the so-called 'energy transition' to green energy (Bridge et al. 2013). In cumulative terms, renewable technologies now represent $24.5 \%$ of global electricity production, with growth set to accelerate following the implementation of the UN Paris Agreement on climate change in 2015 (REN21 2017).

Wind energy technologies represent a central pillar of this rapid growth and investment in renewables, contributing 40\% of all capacity added in 2015 (GWEC 2016). Extending from its origins within Europe, the geographical reach and penetration of the wind energy sector is increasingly global. Within this broader pattern of wind industry growth, offshore wind technologies represent a relatively new, but increasingly important, sector. Despite still accounting for only $1.5 \%$ of EU electricity consumption, relative to the $9.9 \%$ derived from onshore wind, the rates of growth and investment in offshore wind are outpacing other renewable energies. Between 2014 and 2015 alone, offshore wind doubled its share of all wind power installations in Europe to $24 \%$ whilst capturing $34 \%$ of all clean energy investment (£13.2 billion) (EWEA 2016). Moreover, in 2016-2017, a series of projects have signalled an accelerating rate of cost reduction and support high-growth projections of a fivefold increase in European offshore wind capacity to 66 Giga Watt (GW) by 2030 (EWEA 2015). 
Given this dynamic industrial context, our approach provides two important contributions. First, while existing research has analysed the structure and organisation of the broader wind industry in terms of value chains (Elola et al. 2013; Lema et al. 2011), we adopt more of a GPN perspective incorporating of a broader range of actors beyond the firm, including the state - to better understand the dynamics within the offshore wind sector. Second, by focusing on the offshore wind industry specifically, we analyse an emerging sector with new and distinctive dynamics and characteristics (see Table 1). In the remainder of this section, we discuss the growth and organisation of the offshore wind industry in relation to: its distinctive characteristics and evolution; the role of the state; production networks and the emergence of lead firms; and its concentration in particular nations. This is designed to provide the global industry context that frames the subsequent national case study sections.

\subsection{Characteristics of the offshore wind industry}

Originating with the inauguration of the world's first offshore wind farm in 1991 at Vindeby, off the Danish coast, the offshore wind sector has subsequently been transformed from a small niche market into to an emergent industry relatively distinct from its onshore equivalent (see Table 1). First, offshore wind farms are much more technologically complex than those onshore, particularly in terms of deployment, grid-connections and the incorporation of in-sea and sub-sea elements. Second, reflecting the challenges posed by the marine environment, deployment activities such as Operations and Maintenance $(\mathrm{O} \& \mathrm{M})$ are of far greater importance, with $\mathrm{O} \& \mathrm{M}$ being seen as being a "rapidly developing sector in its own right" (Crown Estate 2013). Third, the additional complexity of offshore wind demands additional levels of capital investment, with increased time to market requiring considerable financial and organisational resources. Fourth, given the capital intensity of offshore wind and the long-lead times on returns, the extent, visibility and long-term commitment of government 
subsidies for the sector are crucial for sustaining investment (WindEurope 2016). As a consequence, the structure of the offshore wind sector is dominated by a small number of large scale investors able to absorb the additional costs and long-term returns.

The combination of high cost and state subsidies has focused attention on cost reduction. Until very recently, estimates in Europe suggested that offshore wind would need to reduce its costs by 26\% to Euro 100/Mega Watt Hour (MWh) by 2020 and 90 MWh by 2030 to achieve cost competitiveness with conventional energy sources (EWEA 2015). However, 2016 represented a breakthrough year with a significant acceleration in the pace of costreduction to already exceed the 2020 target of Euro $100 \mathrm{MWh}$. Leading wind farm developer DONG was awarded a contract to build the Borssele $1 \& 2$ project in the Netherlands in June for a price of Euro 72 per MWh, followed by a price of Euro 54 per MWh for Borssele $3 \& 4$ in December, both excluding transmission costs (GWEC 2017, p. 59).

Whilst still representing only 2\% of global wind capacity (GWEC 2015), offshore wind's contribution to new annual wind capacity is increasing rapidly, especially in Europe and China. Within Europe, offshore wind achieved a 31\% 5-year compound annual growth rate up to 2015 , culminating in over $11 \mathrm{GW}$ installed across 84 offshore wind farms in 11 countries (EWEA 2016). Supported by China's expected tripling of capacity to 7.5GW by 2020, medium level growth scenarios predict global capacity to more than double by 2020 (GWEC 2016; Ernst and Young 2015).

A key driver of growth is the potential to access higher wind speeds from the open sea, whilst also having more space to increase the size and number of turbines to achieve higher rates of energy capture. A further advantage is the perception that offshore wind offers fewer of the 
often politically contentious aesthetic and amenity impacts of onshore developments (though see Haggett 2008). Indeed, for countries with a well-developed onshore wind market like Denmark and Germany, offshore wind offers opportunities for continued growth in the face of a saturated market with ever fewer viable land-based sites (Markard and Peterson 2009; Ernst and Young 2015). The growth of offshore wind is characterised by the so-called trend to 'bigger, deeper and further' (EWEA 2011), allowing larger turbines to be built in ever deeper waters away from shorelines. This trend looks to be extended further with recent innovations around floating wind turbines, as opposed to the conventional fixed-bottom model, allowing additional capacity to be added further offshore or along coasts that lack shallow waters, such as Japan, Norway and USA (Steen and Hansen 2014). 
Table 1: Comparison of onshore and offshore innovation characteristics (Source: Markland and Peterson 2009)

\begin{tabular}{|c|c|c|}
\hline & Offshore & Onshore \\
\hline \multicolumn{3}{|c|}{ Site related and technological characteristics } \\
\hline $\begin{array}{l}\text { Specific electricity } \\
\text { production }\end{array}$ & High (due to high work load factor) & Smaller than offshore \\
\hline General restrictions & $\begin{array}{l}\text { Water depth, nautical routes, nature } \\
\text { reserves, distance from the coast }\end{array}$ & $\begin{array}{l}\text { Wind exposition, residential areas, nature } \\
\text { reserves }\end{array}$ \\
\hline $\begin{array}{l}\text { Environmental } \\
\text { conditions }\end{array}$ & $\begin{array}{l}\text { Rather strong and steady wind speeds, salt } \\
\text { water, waves, extreme weather conditions }\end{array}$ & $\begin{array}{l}\text { Lower, less steady and more turbulent } \\
\text { winds than offshore }\end{array}$ \\
\hline Access conditions & $\begin{array}{l}\text { Erection only at calm wind and sea } \\
\text { conditions, restricted access (e.g. for } \\
\text { trouble shooting, maintenance), long } \\
\text { distances }\end{array}$ & $\begin{array}{l}\text { Erection at calm wind conditions, road } \\
\text { access required, transport of rotor blades } \\
\text { more challenging, maintenance easier }\end{array}$ \\
\hline $\begin{array}{l}\text { Environmental } \\
\text { impacts }\end{array}$ & $\begin{array}{l}\text { Visual impact \& noise of little relevance, } \\
\text { potential impacts on sea birds and } \\
\text { migrating birds, impacts due to foundation } \\
\text { and grid connection }\end{array}$ & $\begin{array}{l}\text { Visual impact and noise often highly } \\
\text { relevant }\end{array}$ \\
\hline Grid connection & $\begin{array}{l}\text { Long distances to coupling points, } \\
\text { condition monitoring necessary, separate } \\
\text { licence procedure(s), weak costal grids }\end{array}$ & $\begin{array}{l}\text { Low to medium distances, grid integration } \\
\text { less problematic because wind park size } \\
\text { smaller }\end{array}$ \\
\hline \multicolumn{3}{|c|}{ Economic characteristics } \\
\hline Major cost drivers & $\begin{array}{l}\text { Turbines, foundations, grid connection } \\
\text { and transformer station }\end{array}$ & Foundations and grid connection less costly \\
\hline Capital need & High & Low compared to offshore \\
\hline Risks & High, lack of insurance & Low compared to offshore \\
\hline Income & $\begin{array}{l}\text { Governmental support schemes, partly } \\
\text { with extra incentives for offshore wind }\end{array}$ & Governmental support schemes \\
\hline \multicolumn{3}{|l|}{ Organizational aspects } \\
\hline $\begin{array}{l}\text { Planning and licensing } \\
\text { procedures }\end{array}$ & $\begin{array}{l}\text { Huge national differences, often complex } \\
\text { and time consuming }\end{array}$ & Similar to offshore \\
\hline Grid connection & $\begin{array}{l}\text { Close coordination with grid operator } \\
\text { essential (especially when grid expansion } \\
\text { required) }\end{array}$ & $\begin{array}{l}\text { Coordination also important but less } \\
\text { critical }\end{array}$ \\
\hline Project size & Large & Smaller than offshore \\
\hline $\begin{array}{l}\text { Number of different } \\
\text { parties/subcontractors }\end{array}$ & Large, more complex project management & Smaller, less complex \\
\hline Further particularities & $\begin{array}{l}\text { Field work/schedules highly dependent on } \\
\text { weather and sea conditions, availability of } \\
\text { e.g. vessels may cause bottlenecks }\end{array}$ & Lower dependencies compared to offshore \\
\hline
\end{tabular}




\subsection{Supra-national and national regulation and planning}

Historically, the state has played a key role in the development of the wind industry, notably in the domains of energy market regulation (horizontal), industrial policy (vertical) and spatial policy. A range of energy market instruments such as feed-in-tariffs, quotas, renewable obligations (ROs), public $\mathrm{R}$ and $\mathrm{D}$ funding and carbon taxes have been introduced to support and protect the 'infant industry' before wind could become price competitive with established energy sources (Essletzbichler 2012). This is particularly salient for offshore wind, despite accelerating rates of cost-reduction (Ernst and Young 2015; 4cOffshore 2016). Nonetheless, the large-scale and long-term potential of offshore wind provides a strategic opportunity for states to address renewable energy targets, energy security and volatile fossil fuel prices, whilst also offering the potential for industrial development and economic growth (WindEurope 2016a; Ernst and Young 2015).

Renewable energy targets operate primarily at the national and supranational scales. The European Union's 2009 Renewable Energy Directive set a legally binding target to achieve 20 per cent of final energy ( 34 per cent of electricity) from renewables by 2020 . The EU estimated that wind power would deliver 12 per cent of electricity by 2020 , a target already exceeded in 2016 (EWEA 2011; Wind Europe 2016). In 2014, the EU agreed further 2030 targets to reduce emissions by $40 \%$ below 1990 levels and to reach $27 \%$ use of renewables for total EU wide energy. Whilst the 2030 targets are not currently binding at the national level, the recent moves towards an EU Energy Union suggest a reduction of national autonomy in renewables policy as the EU seeks to become the "world number one in renewables" (Junker 2014). As such, wind energy is expected to provide the largest component (23.9\%) of the EU's target of 27\% of energy from renewables by 2030. 
At the same time, state support remains subject to altered political strategies and pressures (Steen 2016). This can create uncertainties that constrain investment and growth (GWEA 2014). For example, since 2010, the adoption of fiscal austerity programmes, the rise of alternative unconventional sources (e.g. shale gas) and the lobbying by powerful carbonbased incumbent producers have variously coalesced to exert increased pressure on renewables support, prompting policy adjustments and some reduction in subsidies in a number of European countries including Germany, the UK and Spain (Chazan 2013; Dawley et al. 2015). More recently, the potential impact of Brexit on UK-EU on energy policy cooperation and implications of the Donald Trump Presidency for US renewable energy have raised further uncertainties.

In addition to creating a market for offshore wind, states have been active in fostering the industrial and economic development of the sector. The dominance of Danish (e.g. Vestas) and German (e.g. Siemens, REpower) turbine manufactures in the European and internationals market reflects how targeted state support around wind-related research and development (R\&D) and industrial development was allied to energy market policies that stimulated domestic demand (Garud and Karnoe 2003; Campos Silva and Klagge 2013). By contrast, despite being the world's largest offshore wind market, the UK possesses no domestic offshore wind turbine manufacturers and is wholly reliant upon either turbine imports or the attraction of FDI turbine assembly plants. Conversely, the state's orchestration of offshore wind in China reflects a model of planning and intervention characteristic of a developmental state approach (see Yeung 2014). From the late 1990s, state-owned turbine manufacturers were established and through a policy of 'trade-market-access-for-technology' engaged in joint ventures and technological licencing agreements with European producers (Campos Silva and Klagge 2013). Concurrently, China began to implement a strict policy on 
local content requirements in turbine manufacture, rising to 70 per cent from 2004 to 2010. As a result, Chinese turbine manufacturers supplied 90 per of domestic demand in 2010, whereas 70 per cent of the market was supplied by subsidiaries of foreign firms in 2005 (Lema et al. 2014; Campos Silva and Klagge 2013).

The other main way in which the state shapes the development of offshore wind is through the planning process (Jay 2010). The rapid growth of offshore wind has stimulated a new set of agendas and challenges for marine spatial planning, highlighting it's divergence from onshore wind and terrestrial spatial planning (Gazzola, Roe and Cowie 2015). As we elaborate in our case study analyses (Sections 4-6), planning for offshore wind is subject to a range of nationally-specific institutional arrangements. Generally, however, offshore wind developments are required to go through a lengthy planning and consenting process, involving highly costly environmental assessment of marine sites, and typically extending across the first three to four years of the project development process. The cost and risks of environmental assessment and other pre-consent work are generally borne by the developers. However, more recently new national models have emerged in Germany, the Netherlands and Denmark whereby much of the planning and consenting is now undertaken by the state, thus enabling developers to bid on the basis of greater certainty and security (4cOffshore 2016). These new national approaches may reflect the maturing and development of the planning process, which in the early years of the offshore wind sector represented something of a regulatory deficit (Jay 2010). In most cases, central government departments have taken more control of the offshore wind planning process, especially in response to developers' complaints about the protracted and fragmented nature of earlier processes (Gazzola, Roe and Cowie 2015). 


\subsection{Production networks, manufacturing and deployment}

As part of the broader understanding of global production networks developed in this paper, important insights can be drawn from existing work examining the narrower notion of value chains in the wind sector. In particular, Lema et al $(2011 ; 2014)$ identify a two-pronged production network within the wind industry composed of a manufacturing chain and a deployment and services chain (Figure 3).

Figure 3: The Basic Wind Industry Value Chain (Source: Lema et al. 2011).

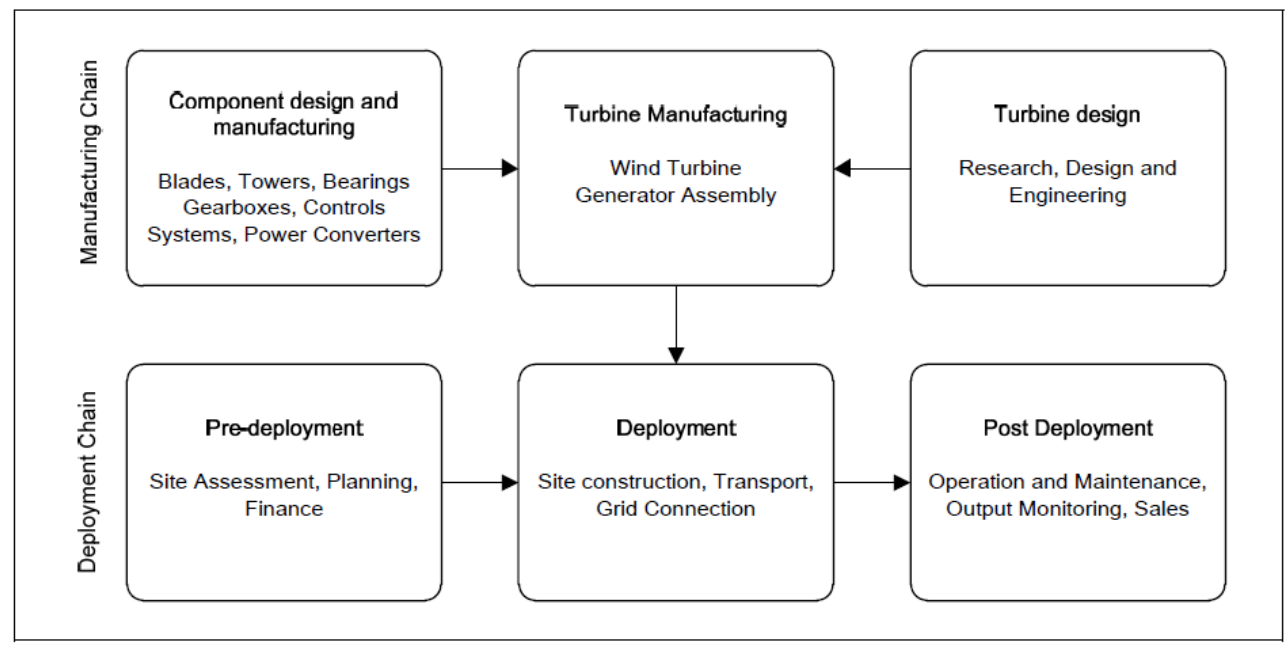

Sources: Drawing on Frost and Sullivan (2010); EWEA (2007); EAI (n.d.); CCB International (2011). Arrows indicate flows of goods and services between functions in the chain.

The manufacturing network focuses on the assembly of the wind turbine. The wind turbine manufacturer acts as a strategic partner to the developer, coordinating the assembly of a turbine which may require over 8,000 components, including key items such as gearboxes, blades, towers etc. Taken together, the assembly and components of a turbine represent around 70 per cent of the capital expenditure on onshore wind projects (Lema et al. 2011). By contrast, given the added complexity of the offshore sector, the value of the assembled turbine represents as little as 26 per cent of the overall capital expenditure, with the so-called Balance of Plant (BoP) comprised of the foundation structures to secure the turbine to the 
seabed, electricity sub-station and cabling accounting for another 19 per cent (BVG Associates 2014: 12). In the European market, Siemens is the lead turbine supplier with 63.5\% per cent of installed capacity, followed by MHI Vestas with 18.5 per cent (EWEA 2016).

The deployment and services network conventionally applies to pre-deployment (planning, finance etc.), deployment (site construction and grid connection) and post-deployment ((O \& M). For offshore developments, a much larger proportion of capital expenditure resides in deployment, particularly operations, maintenance and services (39\%), but also installation and commissioning (14\%) (BVG Associates 2014). Specialist vessels and subsea equipment are needed for operations, maintenance and services as well as installation, together with dedicated port infrastructures. Utility companies often act as the lead firms across the industry, serving as project developers and managers. This not only reflects the requirements placed on utilities to deliver more renewable energy, but also the financial resources available to large utility firms to absorb the costs of offshore wind development. Indicative of broader trends of internationalisation within the energy and utilities sector, key lead firms such as DONG (DK; 15.6\%), E.On (IT; 9.6\%); Vattenfall (SE; 8.9\%), and RWE (DE 6.4\%) have extended beyond their domestic markets to own $50.6 \%$ per cent of European capacity (Elola et al 2013; EWEA 2016).

The manufacturing and deployment networks also exhibit different levels of geographical mobility. Apart from the tendency to locate final assembly functions (i.e. the turbine) near to the wind farm site due to the size of the structures and the cost of transporting them, more specialised manufactured components are typically sourced on a much wider geographical basis, with most turbine manufacturers having established supply chains in a small number of 
locations to help reduce costs and improve inter-firm knowledge flows. Firms in the deployment chain, however, typically have less geographical mobility as they are more tightly aligned to individual wind farms to enable more frequent servicing and support in addition to the installation and regular maintenance of equipment. This demonstrates the potential for many in situ maritime and offshore oil and gas (O\&G) firms, located in port and coastal areas, to branch into the offshore wind sector. For example, in contrast to turbine manufacture, the provision of services such as vessel operation and maintenance and the inspection and repair of turbine components presents a lower set of technical barriers to entry for local firms, providing opportunities for areas proximate to offshore wind farms (EWEA 2011). Put another way, given that the deployment chain and balance of plant contribute the majority of value in offshore wind, a country does not necessarily need a domestic turbine manufacturer to develop a significant presence in the industry.

In general, offshore wind has been characterised as a relational production network (Gereffi et al. 2005) exhibiting high levels of collaboration, cooperation and knowledge exchange between lead firms and suppliers to meet the technological and locational challenges of the sector. By contrast, the onshore wind network is becoming less relational and increasingly modularised through more standardised technology and more geographically extensive supply chains, especially in high growth markets beyond Europe (Elola et al. 2013).

\subsection{Leading Nations}

Geographically, the offshore wind industry's growth has centred on the European market, now possessing $91 \%$ of global capacity, including over 3,500 turbines installed in 81 wind farms across 10 countries (GWEC 2017; see Table 2). However, despite its Danish origins, the growth of the European sector remained irregular and confined to small scale near shore 
development in Danish and Dutch waters until 2001 (EWEA 2011). Not until two larger scale wind farms were installed and grid connected in Sweden (Utgunden) and Denmark (Middelgrunden) in 2001 did the industry begin its rapid rise. Denmark, Germany, UK, Netherlands, Sweden and Belgium have since dominated the growth of the European market (Table 2). Denmark's pioneering role in the offshore wind industry gave it the largest market until 2010 when it was overtaken by the UK. By 2020, market growth is projected to be greatest in the UK, Germany, Netherlands, Sweden and Belgium respectively (see Figure 5). As indicated above, however, the scale and scope of industrial development within offshore wind does not simply mirror market size. Despite no longer having the largest market, Denmark's first mover advantages means it continues to be at the heart of global production networks within the wind industry, closely followed by Germany (Simmie 2012; Lema et al 2011).

Led by China, the sector's growth is now extending beyond Europe (GWEC 2014). Until recently, China's aspirations to become the world's largest market by 2020 have been reigned back by the relatively modest development of state feed-in tariffs and a series of technological and administrative difficulties. Elsewhere, Japan has a project pipeline expected to deliver just under $1.5 \mathrm{GW}$ of power by 2020 , but faces technological challenges in developing floating offshore wind technologies to cater for its deep seabed.

Finally, despite possessing 17.2 per cent of the world's onshore wind power capacity, the USA possesses only an embryonic offshore wind market (GWEC 2016). Established energy market structures and difficulties in negotiating state and federal level planning procedures have so far hindered commercial developments. In 2017, the 30 MW Block Island project off 
Rhode Island will become the USA's first commercial offshore wind farm, ahead of other projects taking place in the fresh water environments of the Great Lakes.

Figure 4: Global Cumulative Offshore Installed Capacity in 2015 (MW) (Source: GWEC 2016 p.49)

\section{ANNUAL CUMULATIVE CAPACITY (2011-2015)}

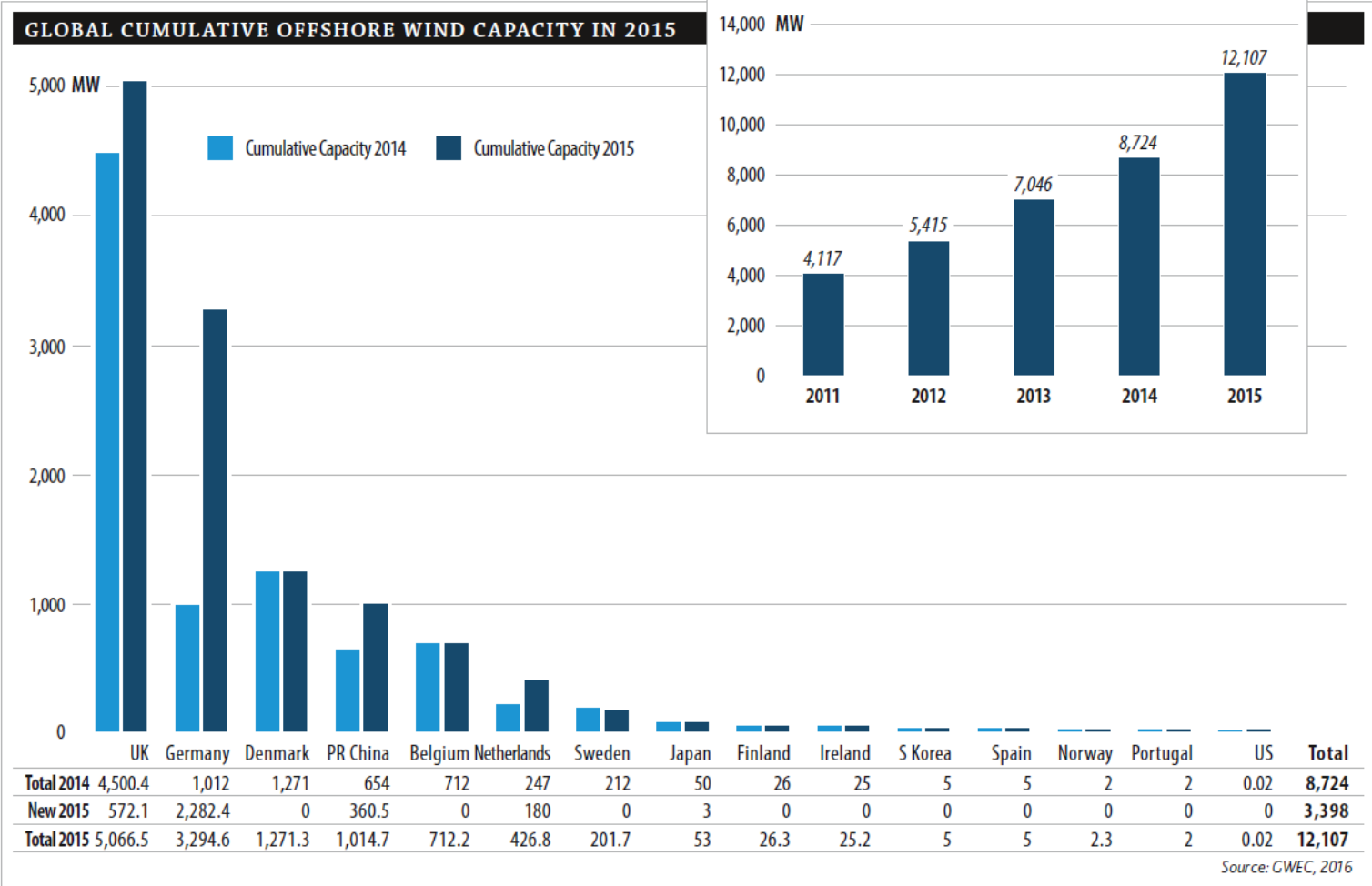


Table 2: Leading European nations by offshore wind farms, turbines and MW fully connected to the grid (Source GWEC 20-17, Annual report 2016 p.60)

\begin{tabular}{|c|c|c|c|c|c|c|c|c|c|c|c|}
\hline Country & BE & $\mathrm{DE}$ & DK & ES & FI & IE & NL & NO & SE & UK & Total \\
\hline $\begin{array}{l}\text { No. of } \\
\text { farms }\end{array}$ & 6 & 18 & 13 & 1 & 2 & 1 & 6 & 1 & 5 & 28 & 81 \\
\hline $\begin{array}{l}\text { No. of } \\
\text { turbines } \\
\text { connected }\end{array}$ & 182 & 7947 & 517 & 1 & 11 & 7 & 365 & 1 & 86 & 1,472 & 3,589 \\
\hline $\begin{array}{l}\text { Capacity } \\
\text { Installed } \\
\text { (MW) }\end{array}$ & 712 & 4,108 & 1,271 & 5 & 32 & 25 & 1,118 & 2 & 202 & 5,156 & 12,631 \\
\hline
\end{tabular}

Figure 5: National Offshore Wind Capacity Targets (Source: Carbon Trust 2014, p.8)

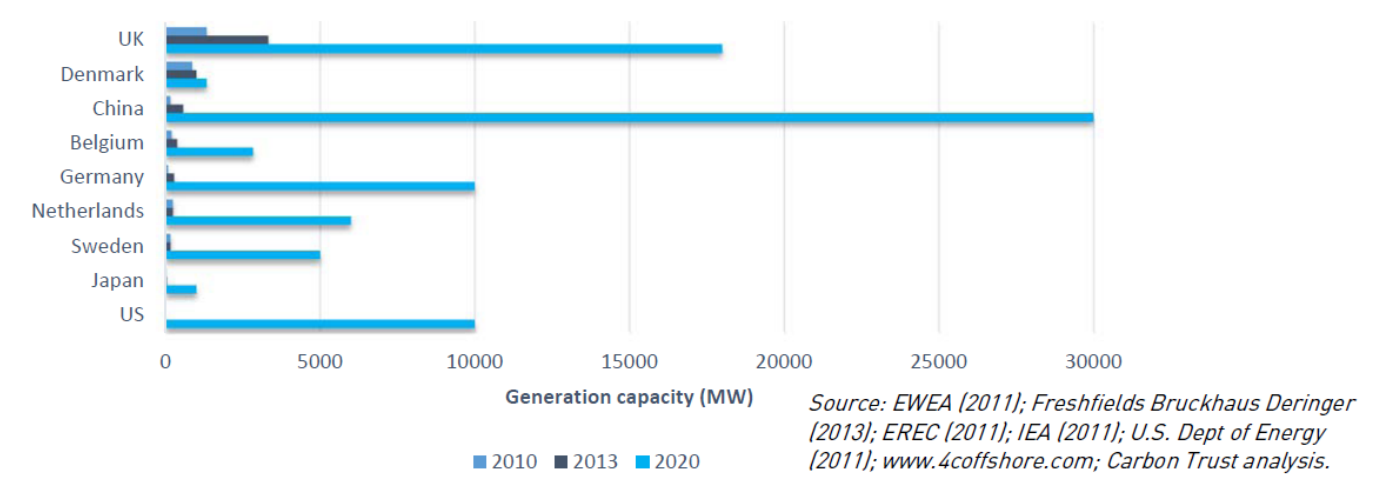

The analysis developed in this paper provides a comparative cross-national analysis of path creation in offshore wind in its European heartland. Given that Denmark's pioneering role in the broader wind industry has understandably dominated research to date (inter alia Garud and Karnoe 2003; Karnoe and Guard 2012; Simmie 2012), our analysis responds to calls for the extension of the base of comparative analysis within both the wind industry (Elola et al. 
2013) and EEG (Neffke et al. 2011). In particular, within the relatively young life of the offshore wind industry, we focus on three European countries surrounding the North Sea basin: Germany, United Kingdom and Norway. Their contrasting development paths provides a robust comparative platform for our analysis of the relationships between regional assets, actors, mechanisms of path creation and multi-scalar institutional environments.

The policy regimes that shape the development of offshore wind at the national and regional scales can be market-led, industry-led or involve a balance of the two, based on our earlier distinction between horizontal and vertical forms of policy and reflecting the distinct VoC that have shaped the industry's development (Cetkovic et al. 2016). The UK is a 'simple' LME, favouring a limited state, competition and market demand, alongside a centralised political structure. Germany corresponds to a 'compound' CME, based on its high level of strategic coordination between firms and institutions and its federal structure, whilst Norway represents a 'simple' CME characterised by a combination of strategic coordination and a unitary state (ibid). Accordingly, the UK's approach to offshore wind has been market-led, resulting in it lagging behind on industrial development. Its offshore wind industry emerged from 2001, before experiencing rapid growth from the mid-2000s (Dawley et al 2015). By contrast, Germany has not only developed a domestic market for offshore wind based on long-term energy policies, but also a world leading and integrated offshore wind industry. It can be regarded as the most mature of our cases, reflecting its role as one of the early pioneers of wind energy with offshore pilot projects established in the 1980s and 1990s (IRENA-GWEC 2012). Finally, reflecting its existing energy mix, Norway has not established a domestic market for offshore wind, meaning that the industry remains embryonic, although the state has provided coordinated support for research and development initiatives and sectoral branching from O\&G (see Section 6). The UK has the largest offshore 
wind market with just under 5.156 megawatts (MW) of installed capacity in 2016, compared to 4,108 MW in Germany and only $2 \mathrm{MW}$ in Norway (Table 2).

The following three sections of the paper present the national case studies, with each adopting a common structure. This begins with the origins and development of the respective offshore wind industries with particular reference to the underlying regional and national assets upon which this is based. We then turn to the broader institutional environment and state policy, reflecting the role of states in the formation of renewable energy markets in recent decades. This is followed by an account of the principal mechanisms of path creation in each case, focusing on firms, FDI and branching. The emerging geography of offshore wind development is then assessed in terms of the emergence of leading regions prior to a brief summary of the cases. 


\section{Path Creation in Offshore Wind: the case of Germany}

\subsection{Origins and development path}

Relative to the UK and Norway, Germany's current position builds upon a tradition of activity in wind energy from the late 1970s. Onshore wind technologies have so far dominated this growth trajectory, producing $98.5 \%$ of wind generating capacity and employing 119,000 (GWEC 2014; O'Sullivan et al. 2014). More recently, however, attention has increasingly shifted to offshore wind as a scalable solution to Germany's ambitious energy transition targets (the so called Energiewende) (Bundesregierung 2002). Germany now represents the world's second largest market for offshore wind alongside a worldleading offshore wind industry representing over Euro 10 bn in cumulative investment, a turnover of EUR 1.9 billion and 18,800 workforce (GWEC 2015; O'Sullivan et al. 2014).

Despite some limited pilot offshore wind projects in the 1980s and 1990s, it was the publication of Federal Government's 2002 Offshore Wind Strategy that catalyzed the sector (Bruns and Ohlhorst 2011). The evolution of the fledgling industry faced a number of distinctive challenges, however, emerging from Germany's natural and material asset base. First, relative to the UK's abundant marine assets, Germany's relatively short coastline constrains the potential scale for development in territorial waters. Second, the National Park status of large tracts of Northern and Western coast has meant that development is mostly confined to relatively deeper (ca. 40 metres) and rougher waters in the 'Exclusive Economic Zone' (EEZ) 12 nautical miles off the coast (Cetkovic et al. 2016, p. 14). This created additional challenges for the securing of turbines to the seabed and connecting them to the grid. 
In response, the government established various $R \& D$ and demonstration programmes to help stimulate market confidence and industrial development. A pivotal project was the Alpha Ventus test-site programme, becoming Germany's first offshore wind farm in 2009 and stimulating the rapid ramp-up of commercial offshore developments in Baltic 1 (2011) and BARD 1 (2013). By 2014, the German market had grown to a capacity of $1 \mathrm{GW}$, with over 258 turbines installed. Capacity tripled further in 2015 with an additional $2 \mathrm{GW}$ connected to the grid, allowing Germany to exceed the UK's levels of annual additional capacity added.

\subsection{State Policy}

The recent rise of offshore wind is situated within Germany's distinctive historical context of experimentation with alternative energy from the late 1960s. Connected to a long-term opposition to nuclear power and the rise of the Green Party movement, Germany became an early adopter of state legislation to support and subsidise renewable energy. In the context of a 'compound' CME (ibid), Simmie et al. (2014) suggest that the historical influence of multiscalar electricity generation, distribution and supply (national, regional and municipal) provided the scope for experimentation and the development of alternative energy trajectories at Lander and municipal levels.

Within this historical institutional context, the onshore wind industry began to emerge in the 1970s from relatively small-scale projects driven by innovators and entrepreneurs, the socalled 'Tuftler' (do-it-yourselfers). A second period of accelerated growth occurred in the 1990s primarily driven by the Electricity Feed-in-Act (StrEG) of 1991, effectively providing a fixed rate for renewable projects to feed into the national grid network. A third period of growth followed the implementation of the Renewable Energy Sources Act (RESA) in 2000 which provided a feed-in tariff for each $\mathrm{kWh}$ produced and priority grid connection for 
renewable energy. However, by the early 2000s, the institutional environment for onshore wind became increasingly constrained as local and national political opposition grew to the spatial and aesthetic impacts of development.

The Federal Government's adoption of the radical Energiewende, aiming to transform the economy away from fossil resources, triggered a shift in focus towards offshore wind. With the implementation of the Renewable Energies Act (Erneuerbare-Energien-Gesetz) of 2000 (Bundesregierung 2002), the objective of a complete transition from fossils fuels was made explicit along with specific target shares for renewable energy technologies. The Energiewende was also connected to the phasing out of nuclear energy, first implemented via the Atomic Energy Law (Atomgesetz) in 2002 and subsequently accelerated, following Fukushima in 2011, by the decommissioning of all nuclear reactors by 2022 . Therefore, allied with the federal strategy for offshore wind in 2002, the sector's growth has been reinforeced by the Energiewende. As part of which, the Renewable Energies Act was adjusted in 2004, 2009, 2011, and 2014 (see below).

\subsubsection{Energy Market Regulation}

Germany has been an international pioneer in the use of demand-side instruments to help stimulate and protect an emerging market for renewable energy. Estimates suggest that the use of feed-in-tariffs have stimulated the growth of renewable energy from $7 \%$ of electricity generation in 2000, to 23\% in 2012 and 30\% in 2014 (EFI 2014 cited in Nordensvard and Urban 2015).

In terms of wind energy, the implementation of StrEG (1991) served as a principal "demandcreating policy incentive" (Lema et al. 2014 p. 36) creating a framework which obligated and 
subsidized the connection of wind energy to the national grid. The StrEG set a feed-in-tariff of $90 \%$ of the average retail electricity price for wind producers, compared to $65-80 \%$ for other renewable energy technologies. It was complemented by a supply-side policy which provided loans or grants that subsidized the cost of buying a turbine by up to $50 \%$ through the state-owned Deutsche Ausgleichsbank development bank.

The 2000 Renewable Energy Supply Act (RESA) provided a further step-change by awarding renewable energy priority grid connection, whilst also setting a new fixed price designed to mitigate the impact of falling energy prices (Wüstenhagen and Bilharz, 2006). A two-part tariff was designed for wind energy, fixed for the first 5 years and then variable for the next 15 years based on local wind conditions. Offshore wind enjoyed a higher rate than onshore wind at 9.1 and 6.19 cents per kilowatt hour respectively (equating to 90.1 and 61.0 Euros per megawatt hours respectively). Yet, despite the 2002 Offshore Wind Strategy's target of 2-3 GW of installed capacity by 2010, the high costs and perceived risks of offshore wind energy production meant no capacity had been installed by 2008 (Markard and Petersen 2009). In response, the 2009 revision of the EEG increased feed-in-tariffs for offshore wind to reflect the high costs of turbine installation in deeper and more distant waters.

The 2014 revisions to the RESA focused on three core objectives for German energy policy: lower costs; diversifying the market; and achieving renewable targets. The Act established the renewable energy targets of 40-45\% share of energy mix by $2025,55-60 \%$ by 2035 and $80 \%$ by 2050 . It also instigated a "game-changing" amendment (GEWC 2015 p.50) with the delivery of technology specific targets, with $2.5 \mathrm{GW}$ for onshore wind per year and a cumulative offshore target of $6.5 \mathrm{GW}$ by 2020 . The divergence between onshore and offshore increased further with the introduction of the "accelerated model" for offshore developers to 
choose between a higher rate $(19.4$ cents per KW/h) over at least 8 years or a lesser rate $(15.4$ cents) for at least 12 years (depending on distance and water depth).

A further "regime change" (4cOffshore 2016) followed the 2017 Renewable Energy Act's adoption of an auction approach to tendering across all renewable energy technologies. This mirrors similar reforms in the UK, Denmark and the Netherlands. The new approach aims to deliver greater visibility and certainty in the market by releasing to tender between 600 900MW per year with the aim of delivering a 15GW target by 2030 . The altered regime reflects a number of key drivers, including domestic political pressures to reduce the levels of subsidy, EU 2014 State Aid rules, and a broader recognition of the maturing of the industry linked to marked cost reduction, especially in return for the enhanced visibility of long-term demand offered by the new approach.

In addition, the Offshore Wind Energy Programme run by the "Kreditanstalt für Wiederaufbau" (KfW) since 2011 has provided supply-side support through loan arrangements for the installation of offshore turbines. The KfW is a public bank which fulfills a similar role to the former Green Investment Bank in the UK (now the Green Investment Group, following its sale to the Australian bank, Macquarie). Reflecting growing dependency on a small number of multinational utility firms able to bear the costs and risks of offshore development, the Offshore Wind Energy Programme enables smaller firms and developers to finance an offshore wind park, aiming to create a more diverse market. To date, the programme has funded, for example, the Meerwind, Global Tech I and Butendiek wind farm developments.

\subsubsection{Industrial policy}


Policy support for technological and industrial development of wind energy preceded the introduction of demand-side market creation incentives, reflecting a high level of strategic coordination between state, science and industry (Cetkovic et al. 2016). In 1976, one of the earliest initiatives was the state-led GROWIAN (Groß-Wind-Anlage, Large Scale Wind Turbine) programme seeking to develop a world leading turbine (3MW) (Bruns and Ohlhorst 2011). Comparable to the NASA and Department of Energy funded programs in onshore wind in the United States (US) (Garud and Karnøe 2003), its aim was to combine the expertise of national technology leaders in engineering and aviation. However, like its US counterpart, the GROWIAN project has gained renown as one of the biggest failures in the history of wind energy having been curtailed in 1987 at a cost of DM87 million, twice its anticipated budget (Jaeger 2013). Nevertheless, an important legacy of the programme was a first feasibility study to install wind turbines at sea in 1981, while, a successor, GROWIAN II (WKA60), was successfully installed at the harbor walls of the island of Helgoland in 1990 (Jaeger 2013; Oelker 2005).

In 2001 a new phase of industrial policy emerged as the Federal Maritime and Hydrographic Agency (BSH) (Table 3) commissioned the development of the Alpha Ventus programme which provided a test site. The 2002 federal Offshore Wind Strategy injected further momentum, building upon the demonstration effect from the Alpha Ventus programme. Subsequently, the German Offshore Wind Energy Foundation was formed in 2005, a publicprivate organization designed to manage the Alpha-Ventus R\&D project and catalyse the industry more generally through research and advocacy (IRENA-GWEC 2012). Furthermore, "Research at Alpha Ventus" (RAVE), funded by the Federal Ministry for Economy Affairs and Energy (BMWi-Energie) and hosted at the Fraunhofer Institute for Wind Energy and Energy Systems Technology (IWES) in Bremerhaven (Table 3), linked the R\&D from the 
project to the broader industry. Between 2008 and 2010, the Federal Ministry of Education and Research (BMBF) supported offshore developments with 90.9 million Euro (PWC 2012).

In addition to the federal government, the Lander also have instruments to support the offshore wind energy industry. Firstly, they can subsidise certain investments, in addition to funding from the EU. Secondly, the Lander can support the offshore industry through public infrastructure with ports, for instance, usually under state or municipal ownership. Thirdly, research institutes such as ForWind in Oldenburg and Deutsches Windenergie-Institut in Wilhelmshaven (sold to Underwriters Laboratories in 2014) are dependent on funding by the Lander of Bremen and Lower Saxony respectively.

\subsubsection{Planning regime and spatial policy}

More than $95 \%$ of the installed capacity of authorized wind parks are located in the EEZ of the Northern and Baltic Sea (authors' own calculation) with turbines installed further from shore and in deeper waters than the European average (EWEA 2015). When Alpha Ventus was commissioned in 2001, the EEZ lacked a coherent planning regime. Accordingly, the 2004 Spatial Planning Law (Raumordnungsgesetz), which was extended to encompass the EEZ, marked the start of an attempt to create a distinct planning regime and a regulatory framework (Portman et al. 2009). BSH was required to establish a new dedicated spatial development plan (Raumordnungsplan) for the EEZ (Nolte 2010), published in 2009. Additionally, it became the agency that reviews and authorises applications for offshore wind parks.

The regime underwent a significant overhaul and redirection in 2016. In conjunction with the introduction of a competitive auction based approach, the 2017 Renewable Energy Act 
moves away from a developer-led to a more centralised model of planning and development. Similar to the formats recently adopted in Denmark and the Netherlands, the new centralised model means that the state takes on the responsibility of site location, surveying and grid infrastructure. By shifting the costs and risks of pre-deployment expenditure away from developers, the government aims also to better harmonise regional and site planning and approval processes. Furthermore, the transition to the auction-based and centralized model of development is also aligned with a more strategic approach to planning grid connections. The Offshore Network Development Plan 2025 comprises four grid connections in the North Sea and three for the Baltic Sea, linked to BSH designated 'wind farm clusters' within each zone (Bundesnetzagentur 2016). The new system therefore establishes a roadmap for grid connection, with the liability for connection shifting from the wind farm developers to the Transmission System Operators.

Table 3: Main institutional actors in the German Offshore Wind Sector

\begin{tabular}{|l|l|l|}
\hline Institutional actors & Main Function & $\begin{array}{l}\text { Roles and activities in } \\
\text { Offshore Wind }\end{array}$ \\
\hline $\begin{array}{l}\text { Bundesministerium für } \\
\text { Wirtschaft und Energie }\end{array}$ & $\begin{array}{l}\text { Federal Department } \\
\text { responsible for energy } \\
\text { legislation and guidance of } \\
\text { the German "Energiewende" }\end{array}$ & $\begin{array}{l}\text { Steering the offshore wind } \\
\text { energy development (industry } \\
\text { and energy) via legislation. }\end{array}$ \\
\hline $\begin{array}{l}\text { Bundesamt für } \\
\text { Seeschifffahrt und } \\
\text { Hydrographie (BSH) }\end{array}$ & $\begin{array}{l}\text { Regulatory body at federal } \\
\text { level. Responsible for the } \\
\text { permitting process of offshore } \\
\text { wind farms in the German } \\
\text { EEZ. Role now enhanced } \\
\text { within the 'centralised model' } \\
\text { of government-led } \\
\text { development. }\end{array}$ & $\begin{array}{l}\text { Development of guidelines and } \\
\text { regulatory documents. } \\
\text { Managing and controlling the } \\
\text { compliance of the building } \\
\text { process. }\end{array}$ \\
\hline $\begin{array}{l}\text { Windenergie Agentur } \\
\text { (WAB) }\end{array}$ & $\begin{array}{l}\text { Business development and } \\
\text { networking association. } \\
\text { Biggest offshore wind energy } \\
\text { network in Germany. Partly } \\
\text { financed by the state of } \\
\text { Bremen. }\end{array}$ & $\begin{array}{l}\text { Leading role in the German } \\
\text { offshore wind energy industry. } \\
\text { Networking and knowledge } \\
\text { transfer via forums and fairs. }\end{array}$ \\
\hline
\end{tabular}




\begin{tabular}{|l|l|l|}
$\begin{array}{l}\text { Bundesverband } \\
\text { Windenergie (BWE) }\end{array}$ & $\begin{array}{l}\text { Wind energy association of } \\
\text { Germany }(20.000 \text { members). } \\
\text { Promoting onshore and } \\
\text { offshore wind energy. }\end{array}$ & $\begin{array}{l}\text { Industry lobby group for the } \\
\text { wind energy industry. Provides } \\
\text { intelligence, reports and } \\
\text { organises industry events. }\end{array}$ \\
\hline $\begin{array}{l}\text { Offshore Forum } \\
\text { Windenergie (OWF) }\end{array}$ & $\begin{array}{l}\text { Founded in 2001 one of the } \\
\text { first German lobby groups } \\
\text { and think tanks for offshore } \\
\text { wind energy. }\end{array}$ & $\begin{array}{l}\text { Networking within the offshore } \\
\text { wind energy industry, } \\
\text { discussing legal, financial and } \\
\text { regulatory aspects. }\end{array}$ \\
\hline $\begin{array}{l}\text { Wirtschaftsforum Offshore } \\
\text { Helgoland (WFO) }\end{array}$ & $\begin{array}{l}\text { Networking association and } \\
\text { information channel. }\end{array}$ & $\begin{array}{l}\text { Annual discussion forum of } \\
\text { high ranking industry members. }\end{array}$ \\
\hline $\begin{array}{l}\text { Hamburg } \\
\text { Hamter Erneuerbare Energie }\end{array}$ & $\begin{array}{l}\text { Business development and } \\
\text { networking association for the } \\
\text { Hamburg region. Not } \\
\text { exclusively focused on } \\
\text { offshore wind. }\end{array}$ & $\begin{array}{l}\text { Development and } \\
\text { accompaniment of the } \\
\text { renewable energy industry in } \\
\text { the Hamburg region. } \\
\text { Organisation of workshops and } \\
\text { networking events. }\end{array}$ \\
\hline $\begin{array}{l}\text { Bremerhavener Gesellschaft } \\
\text { für Investitionsförderung } \\
\text { und Stadtentwicklung (BIS) }\end{array}$ & $\begin{array}{l}\text { Business development, } \\
\text { establishment and conversion } \\
\text { of infrastructures in } \\
\text { Bremerhaven }\end{array}$ & $\begin{array}{l}\text { Preparation off offshore related } \\
\text { infrastructures, e.g. terminals } \\
\text { and heavy load areas }\end{array}$ \\
\hline $\begin{array}{l}\text { Fraunhofer-Institut für } \\
\text { Windenergie und } \\
\text { Energiesystemtechnik }\end{array}$ & $\begin{array}{l}\text { Research and Development } \\
\text { institute with focus on } \\
\text { renewable energies with } \\
\text { strong industry connections }\end{array}$ & $\begin{array}{l}\text { Basic R\&D-Activities together } \\
\text { with leading firms of the wind } \\
\text { energy industry. E.g. RAVE- } \\
\text { Project (Research at Alpha } \\
\text { Ventus) }\end{array}$ \\
\hline
\end{tabular}

\subsection{Firms, FDI and Branching}

Lema et al. (2014) suggest that over 200 companies are active in the broader German wind sector, with a third operating in manufacturing and two thirds in various types of deployment activity. In offshore wind specifically, Germany has developed an industrial profile across all areas of the value chain, but especially its world-leading role in turbine production.

In turbine development, a number of overlapping mechanisms and firm-based characteristics help explain this evolution. First, from 2000 onwards a series of indigenous engineering firms, emblematic of the archetypal Mittelstand, became involved in diversification by adapting onshore turbines for offshore conditions. The Northern German Offshore 
Consortium was formed to bring together a number of existing wind turbine manufacturers: pro+pro energy systems, Jacobs and Nordex (Norddeutsches Offshore Konsortium). In 2001, Nordex left the consortium and pro+pro and Jacobs merged to form REpower which would subsequently develop into a leading turbine producer. A further example of diversification occurred with the formation of Multibrid as a subsidiary of tower manufacturer Pfleiderer in 2000, utilizing turbine technologies already developed by German engineering company Aerodyn. In parallel, BARD was formed in 2003 as a dedicated start-up. Together this collection of indigenous engineering firms developed the first multi-megawatt wind turbines for offshore conditions in 2004 (REpower and Multibrid) and 2007 (BARD). By 2009 REpower and Multibrid installed their turbines into the Alpha Ventus test field and BARD at the BARD offshore 1 wind park.

Second, and in contrast to the domestic market focused activities of the indigenous engineering firms that would serve Germany's early wind farm projects, the industrial giant Siemens adopted an 'inside out' investment strategy in becoming the world's leading offshore wind turbine manufacturer (EWEA 2015). Siemens entered the offshore wind market by acquiring the leading Danish wind turbine manufacturer Bonus in 2004. To capture the knowledge and technological assets built up around Bonus, Siemens has maintained the focus of its offshore operations in Denmark, investing in further R\&D facilities in Brande and R\&D and production facilities for blades in Aalborg (Sommer 2015). More recently, however, Siemens has invested in a blade manufacture and assembly plant in Hull, UK (£160m and 1000 jobs) and a nacelle assembly plant at Cuxhaven, Germany (EUR200m, 1000 jobs), its first wind turbine plant in Germany. 
Third, the previously indigenous character of the pioneering German offshore wind producers has since been transformed through an 'outside in' form of development. In 2007 REpower was acquired by the Indian wind turbine producer Suzlon and renamed Senvion in 2014. Under Senvion, the sales of the former Repower have become much more globalised with $80 \%$ of production exported in 2014 (Lema et al 2014). Also in 2007, Multibrid was acquired by the French nuclear company AREVA, to become AREVA Wind. Under Areva, Multibrid's sales have continued to focus mainly on the expanding German, UK markets and emerging French opportunities. By contrast, BARD, the last German owned producer, filed for bankruptcy in 2013.

Beyond turbine manufacture, the industrial growth in other parts of the manufacturing remains more modest. Branching and diversification has been a key mechanisms for growth in towers and foundation structures. Firms like EEW, Georgsmarienhütte (with its subsidy WeserWind), SIAG and Thyssen Krupp have branched out from the steel producing and processing industry to provide foundations for offshore wind turbines. Market penetration has proven difficult, however. Whilst EEW is now a major international supplier for foundations, Cuxhaven Steel Construction and WeserWind ceased production by 2015 (EWEA 2015). Similarly, in offshore sub-station technologies, Siemens has grown into one of the world's top three producers, alongside ABB (Switzerland/Sweden) and Alstom (France). The deployment chain of the German offshore wind sector remains dominated by transnational utility companies. For example, the pivotal Alpha Ventus project involved Vattenfall, whilst DONG has also become a key actor in the German market. However, large German based utilities such as RWE Innogy and E.ON have built upon their domestic market presence to extend their interests into offshore wind markets in the UK, Denmark and Sweden. 


\subsection{Creating regional growth paths}

\subsubsection{Geography of OW development}

Compared to the UK and Norway, Germany's offshore wind sector has developed a more varied geography of growth, especially through the mechanism of branching. For example, the interior regions of North-Rhine-Westphalia, Bavaria and Baden-Württemberg account for $50 \%$ of turnover and $40 \%$ of employment in the offshore wind energy industry, with NorthRhine-Westphalia home to the largest volume of firms operating in offshore wind (PWC 2012; BMWi 2015). This concentration of inland industrial activity is, in part, explained through the strong industrial bases of these Länder and branching from sectors with varying degrees of relatedness. In North-Rhine-Westphalia, large utility companies like RWE and E.ON branched into offshore wind from their existing headquarters, whilst manufacturers of gearboxes and drive trains like Eickhoff and Renk have diversified out of existing engineering and manufacturing activities.

The industry has also formed distinct concentrations of activity in a number of coastal locations. As would be expected, these reflect the evolving geography of offshore generation (Figures 6 and 7), requiring access to deep water sea ports with suitable maritime and engineering infrastructures (Fornahl et al. 2012). Bremerhaven and Cuxhaven, in particular, became key centres for investment in the manufacturing chain (i.e. assembly of turbines and production of rotors and foundations).

At the same time, the more generic coastal locational requirements of $\mathrm{O} \& \mathrm{M}$ has seen investment across a more extensive set of 14 ports at the Northern sea and 6 ports at the Baltic sea (Bmwi 2015). In particular, the island of Helgoland is developing into a major 
service hub for wind farms in the northern German Northern Sea like Nordsee Ost (RWE), Amrumbank West (E.ON) and Meerwind (WindMW).

The remainder of this section will focus on the processes of path creation in two of the most important locations within the German offshore wind sector: Bremerhaven as the centre of production and Hamburg where offshore wind regulation, management and business services are concentrated.

Figure 6: Offshore Wind Farms Installed, under Construction, Installed and in approval process in the North Sea in 2014 (Source: Informationsportal Erneuerbare Energien)
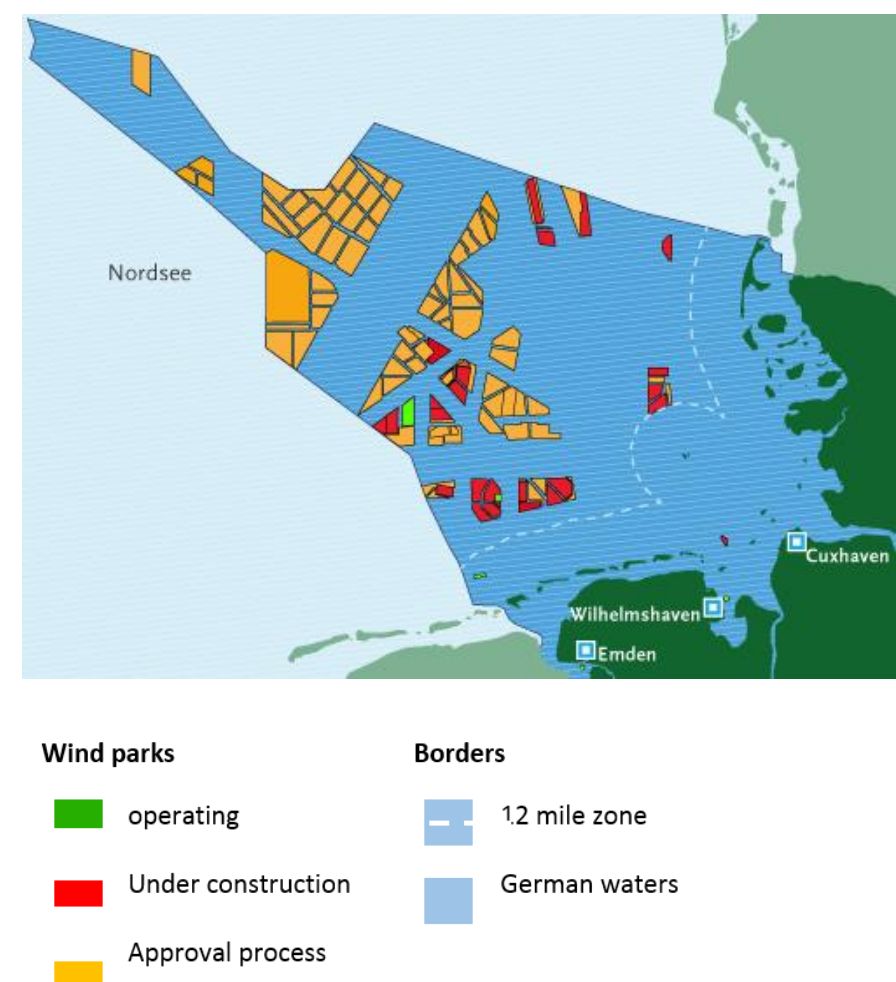

Figure 7: Offshore Wind Farms installed, under Construction and in approval process in the Baltic Sea in 2014 (Source: Informationsportal Erneuerbare Energien) 

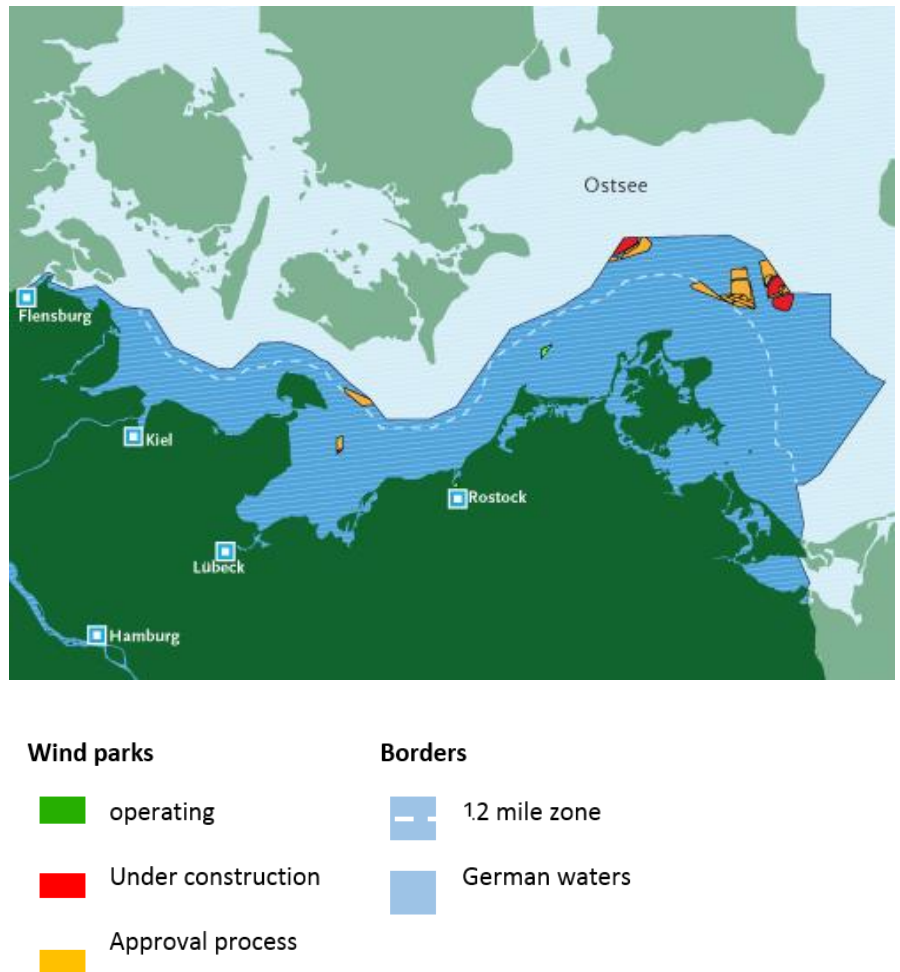

\subsubsection{Bremerhaven and Bremen}

Bremerhaven and neighbouring Bremen's maritime infrastructure builds upon a long tradition of shipbuilding. Like many European shipbuilding centres, the industry began to decline in the 1980s, leading to the closure of Bremer Vulkan, the largest Bremen shipyard, in 1997. Yet the birth of offshore wind in Bremerhaven appears only indirectly related to the shipbuilding crisis with little evidence of shipbuilding firms using related assets to diversify into the emerging sector. Instead, Fornahl et al. (2012) suggests that the city state of Bremen played a critical role in initiating the path creation process. This strategy started in 2001 , driven by Bremerhaven's economic development agency, the Bremerhavener Gesellschaft für Investitionsförderung und Stadtentwicklung (BIS) (Table 3), as part of a cross-party consensus agreed by the State (Land) of Bremen and the City of Bremerhaven.

The strategy developed along a number of interrelated strands. The first involved the conversion and diversification of the redundant shipbuilding and seaport infrastructures into 
dedicated facilities to support offshore wind firms. Given the scale of this conversion, state ownership and investment has proven significant. Reflecting the distinctive 'continental' model of port ownership and governance (Brooks et al 2017; World Bank 2016), the Port of Bremerhaven has been publically owned by the City of Bremen since 1927 and became part of the federal state of Bremen in 1947. This has placed the state and public authorities as key actors in identifying, converting and ultimately valorising important infrastructural regional assets in the process of path creation. In 2010, for example, the Senate of the City of Bremen commissioned the development of the Offshore Terminal Bremen (OTB), at a cost of 160 million Euro for construction and a further 20 million Euro for environmental compensation measures (BIS 2015). Second, BIS adopted a pro-active approach in supporting early activities in offshore wind. In terms of supporting indigenous creation, it fast-tracked planning and consent procedures for Multibrid to use Bremerhaven for a test site for its prototype turbine in the early 2000 s. To ensure geographical proximity to its prototypes and R\&D, Multibrid also located its manufacturing facilities in Bremerhaven (De Vries 2009). Third, BIS was instrumental in developing networks between firms, research institutes and economic development policy from 2001 onwards, together with WAB, a regional cluster organization (Table 3).

Several research institutions also branched into offshore wind related activities in the 2000s as the industry developed, especially those formerly focused on onshore wind (e.g. Fraunhofer Institute for Manufacturing Technology and Advanced Materials (IFAM) in Bremen). More specifically, IWES, founded in 2009 (Table 3), conducts R\&D across all stages of the offshore wind sector including internationally renowned blade test equipment facilities. In terms of skills and labour markets, the Fachhochschule Bremerhaven is one of 
the first applied sciences universities in Germany to offer a degree programme in wind energy.

Following this initial stimulus of indigenous path creation, transplantation from other regions of Germany has been the primary mechanism through which other key firms have subsequently emerged in Bremerhaven, namely: WeserWind (foundation structures and towers) in 2003: REpower (turbine production) in 2008; Powerblades (blades and rotors) in 2008. More recently, the transplantation process has been internationalized with the acquisitions of Multibrid and REpower by AREVA and Suzlon. This 'outside-in' form of development appears to be helping embed the path further with both AREVA and Suzlon retaining their key European operations in the region.

Around 4,000 people are currently employed in the offshore wind energy sector of Bremen and Bremerhaven. Yet the uncertainties over energy pricing systems at the Federal level between 2012 and 2014 impacted on Bremen as well as the broader industry. During this period, the five largest manufacturers reduced employment levels from 2,540 to 1,982 between January 2013 and January 2014 (Arbeitnehmerkammer Bremen 2014), while foundation manufacturer WeserWind filed for bankruptcy in 2015. Following the confirmation of offshore wind pricing mechanisms in the Renewable Energies Act 2014, however, growth and investment has once again accelerated in Bremerhaven's offshore wind sector (BIS 2015). 


\subsubsection{Hamburg}

In contrast to Bremerhaven's production and assembly role, Hamburg has evolved into a site for management and administration. According to Fornahl et al. (2012:,849) Hamburg can be considered to be "the brain port of the offshore wind industry in Northern Germany". Its role began in the onshore wind in 2001 by capturing REpower's relocated headquarters. The city has since attracted $\mathrm{R} \& \mathrm{D}$, administration and management functions across a range of firms, the most notable being the wind headquarters of Nordex and Siemens (with the exception of its offshore operations) in 2011. This administration and management role has subsequently been extended to the rapidly growing offshore wind market. Table 4 describes the firms with offshore wind activities in Hamburg.

In contrast to the policy-driven nature of path creation in Bremerhaven, Hamburg's growth has been very much a firm-led process. This has been driven firstly by transplantation investment. With few exceptions, since 2008 the management and administrations functions of turbine and foundation manufacturers and all utility companies emerging in Hamburg were transplantations. The second, and overlapping, dynamic has been through branching processes, especially in the certification activities. Hamburg has a long tradition of firms that certify new technologies and processes with local firms like GL and TÜV Nord developing early standards for certifying onshore wind turbines from 1977, linked to the GROWIAN programme. These organisations have subsequently branched into the offshore wind sector, beginning in 2001, when GL was involved in the production of the FINO research platforms. Other certifiers like TÜV-Süd, Det Norske Veritas (which merged with GL to DNV GL in 2013) or Deutsches Institut für Normung (DIN) established new offshore activities in Hamburg. In addition to the private sector, Hamburg is the home of the BSH (Table 3). 
A series of interrelated knowledge-based assets have supported Hamburg's emerging offshore wind path. As the offshore wind sector has grown, the knowledge and technical expertise required to manage and coordinate the industry has further enhanced the agglomeration processes in Hamburg. The geographical proximity of manufacturers, developers, utility companies, certifiers, project developers, financial institutions, and insurance companies allows forms of coordination to tackle the complex and non-routinized activities of offshore wind. These knowledge-led growth dynamics are in-part supported by Hamburg's higher education sector, representing over 40,000 students including renowned engineering focused institutions such as Technische Universität Hamburg-Harburg.

Table 4: The Offshore Wind Cluster in Hamburg

\begin{tabular}{|l|l|l|l|l|}
\hline Company & Position in & & & \\
& Value Chain & Country & Function & Year \\
\hline Repower/Senvion & Manufacturer & Germany & Administration & 2001 \\
\hline Areva & Manufacturer & France & Administration & 2011 \\
\hline Gamesa & Manufacturer & Spain & R\&D & 2011 \\
\hline Siemens & Manufacturer & Germany & Administration & 2011 \\
\hline GE & Manufacturer & US & R\&D & 2011 \\
\hline Bilfinger & Foundation & Germany & Administration & 2004 \\
\hline Strabag & Foundation & Austria & Administration & 2011 \\
\hline Ramboll & Foundation & Denmark & Administration & 2011 \\
\hline Vattenfall & Utility & Sweden & Administration & 2002 \\
\hline Dong & Utility & Denmark & Administration & 2011 \\
\hline RWE Innogy & Utility & Germany & Administration & 2008 \\
\hline EnBW & Utility & Germany & Administration & 2009 \\
\hline TÜV-Süd & Certifier & Germany & Administration & 2011 \\
\hline DNV-GL & Certifier & Norway & Administration & 2011 \\
\hline DIN & Certifier & Germany & Administration & 2011 \\
\hline TÜV-Nord & Certifier & Germany & Administration & n.a. \\
\hline GL Windenergie & Certifier & Germany & Administration & n.a. \\
\hline BSH & Certifier & Germany & Administration & n.a. \\
\hline
\end{tabular}


Policy initiatives followed rather than initiated the city's growth path, but play an important role in regionally embedding these developments. Two initiatives are especially important in this respect. The first is Renewable Energies Hamburg, a cluster body established by the city of Hamburg in 2010 (reflecting its designation as European Green Capital for 2011) (Table

3). The second initiative is the "Energie-Campus" of the Hamburg University of Applied Science (HAW) which was established in 2015. The Land of Hamburg and the HAW decided in 2012 to build a technology campus dedicated to the research and development of wind turbines.

\subsection{Summary}

The German case is characterized by an established and strongly growing market, an industry that covers all parts of the value chains (most of it with strong export oriented firms) and a mature policy regime that coordinates market support, planning and industry development (Cetkovic et al. 2016).

A distinctive element in this evolution is the way in which the industrial and infrastructural bases preceded the establishment of the market and helped foster a broader and deeper process of path creation connecting to virtually all parts of the offshore wind value chain. Consequently, when the German market emerged with the first wind farms in 2009, there was already an established base of manufacturers like BARD, AREVA and REpower as well as suppliers like WeserWind, Ambau, Powerblade or Renk. Mechanisms of path creation overlap considerably. For example, in turbine manufacture, only REpower successfully diversified into the offshore sector, while AREVA and BARD were new entries. More significantly, Germany's world leading role in turbine manufacture reflects Siemens diversification strategy of acquiring Bonus and allied Danish assets through transplantation. 
Furthermore, former indigenous firms have more recently developed through 'outside in' investments from Suzlon and Areva.

At the federal scale, the institutional environment has supported path creation through a series of effective demand-side measures. The state has adapted its approach to market formation and development. This is characterised by a strategic vision for industrial growth alongside market growth (Lema et al 2014) stimulating the world's second largest market and a world leading industry.

These broader conditions have interplayed with a variety of regional asset bases and path creation mechanisms to stimulate a series of path trajectories related to particular functions of the offshore wind production networks. In this sense, given the industrial depth of Germany's emerging path, we have witnessed sub-national divisions of labour emerge: innovation and advanced engineering in the advanced industrial regions of the interior (e.g. North-RhineWestphalia); R\&D and management in Hamburg; and engineering and assembly in Bremerhaven. In contrast, for example, the UK's emerging path has a less elaborate subnational division of labour, reflecting the more limited range of functions present. The examples of Bremerhaven and Hamburg show that these places benefitted from a distinctive set of pre-formation contexts, specifically technical and research-led knowledge. These local assets bases were identified and harnessed through overlapping mechanism of path creation, led by firms in Hamburg and by policy actors in Bremerhaven. The evolution of these localised capabilities makes them difficult to replicate elsewhere, particularly in the case of Hamburg. 


\section{Path Creation in Offshore Wind: the case of the UK}

\subsection{Origins and development path}

The historical origins of electricity generated from wind energy can be traced back to the work of Professor James Blyth in Scotland in the late 1800s, yet it would be over a century later before the UK's first commercial onshore wind farm was built in 1991 (Fisher 2015; Renewables UK 2015). The UK's electricity supply system was nationalised in 1947 before returning to private ownership in 1990, an episode in which fossil fuels dominated within a system lacking the same scope for variety and experimentation as the German multi-scalar system of generation and supply (Hannah 1979; 1982; Simmie et al. 2014).

Not until the privatisation of the energy supply industry in 1990 and the introduction of the Non Fossil Fuel Obligation (NFFO) would the UK begin to possess the sort of niche conditions that had helped stimulate the wind industry in Germany, Denmark and the USA. The NFFO required energy suppliers to source a proportion of capacity from renewable sources and marked the origins of subsidy mechanisms. The further expansion of renewables in the 2000s has been driven by climate change considerations with the UK subject to an EU emission target of a 20 per cent reduction in 1990 levels of greenhouse gases by 2020, alongside targets for meeting 15 per cent of energy demand and 30 per cent of electricity demand from renewable sources by 2020 .

The new NFFO market conditions initially appeared to favour the development of the onshore wind market given the UK state's perception of offshore wind as a "long-shot technology" with prohibitive costs (Musgrove 2010 p.155). Following the first commercial project in 1991, the UK's onshore market grew steadily to over $8 \mathrm{GW}$ of power in 2015 , equivalent to $6 \%$ of national electricity demand (Renewables UK 2015). In recent years, 
however, onshore wind growth has been severely challenged by the scarcity of suitable sites and rising political opposition, leading to the removal of all government subsidy and restrictive planning conditions (GWEC 2015).

In parallel, the development of offshore wind began to gain traction in the 1990s as developers, inspired by pioneering projects in Denmark, delivered a small number of successful pilot projects through NFFO funding (Dawley 2014). With increased commitment to climate change goals under Labour governments in the 2000s, offshore wind increasingly emerged as the UK's most scalable renewable technology option. This was predicated upon its underlying asset bases. First and foremost, given its extensive shallow seabed on the UK continental shelf and relatively high and consistent wind speeds, the UK was increasingly recognised as possessing a competitive advantage in its natural resource asset base (Markard 2009; Fisher 2015). Second, the availability of port related infrastructures and adjacent industrial facilities was also identified as a factor which could support offshore development (Crown Estate 2013; Scottish Government 2009). Third, whilst less well developed than Germany, the UK's industrial asset base, especially competences in marine engineering and offshore O\&G fabrication provided a basis for diversification (BVG Associates 2014; HM Government 2013). This was closely associated with allied human assets in forms of skills and experience in these activities, plus a range of deployment activities such as vessel handling and supply, operations and maintenance, surveys, installation and commissioning.

To support the market's growth, the Crown Estate (Table 5) identified and released, over a series of rounds, development zones through which licences are granted to commercial developers to establish wind farms on particular sites. Starting in 2001, Round 1 awarded 13 licences for a capacity of $1.2 \mathrm{GW}$, followed by a second round of licenses for $6 \mathrm{GW}$ across 15 
larger Round 2 sites in 2003. With the release of Round 3 licences in 2009, expansion gathered momentum through the "industrial scale deployment" of up to $33 \mathrm{GW}$ across 9 zones, alongside leases for 10 sites in Scottish Territorial Waters and extensions to round 1 and 2 farms. As a result of this rapid development, the UK overtook Denmark to become the world's largest offshore wind market, possessing $6.1 \mathrm{GW}$ of operational capacity by the third quarter of 2017 (BEIS 2017c, p.63).

\subsection{State Policy}

As outlined above, the national policy context for offshore wind in the UK has been partly driven by climate change targets. In addition, government and industry have stressed the economic opportunity represented by offshore wind as a key sector in which the UK can generate economic value and create jobs in different parts of the country. As indicated earlier, within the confines of a 'simple' LME (Cetkovic et al. 2016), the approach of the UK government has emphasised market development over industrial policy, based upon the use of pricing instruments to promote renewable sources within the UK's liberalised electricity market (Toke and Lauber 2007).

The Department of Business, Energy and Industrial Strategy (BEIS), established in 2016 from a merger of most of the functions of the former Department of Energy and Climate Change (DECC) and the former Department of Business, Innovation and Skills (BIS), is the government department with overarching responsibility for renewable energy policy covering both the 'horizontal' and the 'vertical' dimensions. In addition, the devolved Scottish Government (SG) has espoused a strong political commitment to the development of 
renewables (Table 5), reflecting an important element of asymmetrical decentralisation

within an ostensibly centralised UK policy regime.

Table 5: Main institutional actors in the UK Offshore Wind Sector

\begin{tabular}{|c|c|c|}
\hline Institutional actors & Main Function & Roles and activities in Offshore Wind \\
\hline $\begin{array}{l}\text { The Department of } \\
\text { Business, Energy } \\
\text { and Industrial } \\
\text { Strategy (BEIS) }\end{array}$ & $\begin{array}{l}\text { UK central government } \\
\text { department, formed in 2016, } \\
\text { led by Secretary of State for } \\
\text { Business, Energy and } \\
\text { Industrial Strategy. Brings } \\
\text { together responsibilities for } \\
\text { business, industrial strategy, } \\
\text { science, innovation, energy, } \\
\text { and climate change. }\end{array}$ & $\begin{array}{l}\text { Develops and manages energy markets and } \\
\text { oversees industrial strategy. }\end{array}$ \\
\hline Crown Estate & $\begin{array}{l}\text { Independent commercial } \\
\text { business created by Act of } \\
\text { Parliament. Ownership and } \\
\text { management of seabed with } \\
\text { profits returned to the UK } \\
\text { Treasury }\end{array}$ & $\begin{array}{l}\text { Manages the licensing rounds for offshore } \\
\text { wind farm developments, granting } \\
\text { exclusive rights to developers for particular } \\
\text { sites. }\end{array}$ \\
\hline $\begin{array}{l}\text { Scottish } \\
\text { Government }\end{array}$ & $\begin{array}{l}\text { Devolved government for } \\
\text { Scotland responsible for a } \\
\text { wide range of policy areas, } \\
\text { including economic } \\
\text { development, transport and } \\
\text { infrastructure and planning }\end{array}$ & $\begin{array}{l}\text { Responsible for setting targets for Scotland, } \\
\text { developing overall policy, promoting the } \\
\text { growth of the sector, and issuing planning } \\
\text { consent through its Marine Scotland } \\
\text { department }\end{array}$ \\
\hline Renewable UK & $\begin{array}{l}\text { UK's leading renewable } \\
\text { energy trade association ( } 580 \\
\text { corporate members) in wind, } \\
\text { wave and tidal sectors. Not- } \\
\text { for-profit. }\end{array}$ & $\begin{array}{l}\text { Industry lobby group for the offshore wind } \\
\text { sector. Provides intelligence, reports and } \\
\text { industry events. }\end{array}$ \\
\hline $\begin{array}{l}\text { Offshore } \\
\text { Renewable Energy } \\
\text { (ORE) Catapult }\end{array}$ & $\begin{array}{l}\text { Formed in } 2012 \text { with } £ 46 \\
\text { million of government } \\
\text { funding. One of } 8 \text { UK } \\
\text { Technology and Innovation } \\
\text { Centres (TIC) formed around } \\
\text { priority sector in a recent } \\
\text { centralisation of innovation } \\
\text { policy. }\end{array}$ & $\begin{array}{l}\text { ORE Catapult aims to accelerate the } \\
\text { development, testing, commercialisation } \\
\text { and deployment of offshore renewable } \\
\text { energy technologies. Based in Glasgow, } \\
\text { with an operation and test base in North } \\
\text { East England. }\end{array}$ \\
\hline $\begin{array}{l}\text { Offshore Wind } \\
\text { Industry Council } \\
\text { (OWIC) }\end{array}$ & $\begin{array}{l}\text { Government-industry forum } \\
\text { created in } 2013 \text {, to replace } \\
\text { the former Offshore Wind } \\
\text { Developers Forum (OWDF). }\end{array}$ & $\begin{array}{l}\text { Oversees implementation of the Offshore } \\
\text { Wind Industrial Strategy. Co-Chaired by } \\
\text { Secretary of State for Business and Energy. } \\
\text { OWIC is the sponsoring body of the OWPB. }\end{array}$ \\
\hline $\begin{array}{l}\text { Offshore Wind } \\
\text { Investment } \\
\text { Organisation } \\
\text { (OWIG) }\end{array}$ & $\begin{array}{l}\text { Formed in } 2013 \text { as part of the } \\
\text { Offshore Wind Industrial } \\
\text { Strategy. }\end{array}$ & $\begin{array}{l}\text { Operated within UK Trade and Investment } \\
\text { (UKTI) to help secure inward investment in } \\
\text { such as turbines and foundations. }\end{array}$ \\
\hline
\end{tabular}




\begin{tabular}{|c|c|c|}
\hline $\begin{array}{l}\text { GROW: Offshore } \\
\text { Wind Service } \\
\text { (GROW) }\end{array}$ & $\begin{array}{l}\text { Support for Small and } \\
\text { Medium Enterprises (SMEs) } \\
\text { forming or diversifying into } \\
\text { Offshore Wind. Underpinned } \\
\text { by BEIS but contracted to } \\
\text { consultancies, GROW was } \\
\text { supported by f20m from the } \\
\text { UK's Regional Growth Fund. }\end{array}$ & $\begin{array}{l}\text { Advisors located in } 6 \text { English regions tasked } \\
\text { with acting as one-stop shop for small firms } \\
\text { in accessing market intelligence, business } \\
\text { support, grants and innovation networks. }\end{array}$ \\
\hline Scottish Enterprise & $\begin{array}{l}\text { Regional development } \\
\text { agency for the lowlands of } \\
\text { Scotland. Responsible for } \\
\text { economic growth and } \\
\text { business development. }\end{array}$ & $\begin{array}{l}\text { Provides funds for prototyping and } \mathrm{R} \text { and } \mathrm{D} \text {; } \\
\text { runs a range of supply chain and } \\
\text { diversification initiatives; runs the National } \\
\text { Renewables Infrastructure Funds; interacts } \\
\text { with potential inward investors. }\end{array}$ \\
\hline $\begin{array}{l}\text { Highlands \& Islands } \\
\text { Enterprise }\end{array}$ & $\begin{array}{l}\text { Regional development } \\
\text { agency for the Highlands \& } \\
\text { Islands of Scotland. } \\
\text { Responsible for economic } \\
\text { growth, business } \\
\text { development and } \\
\text { strengthening communities. }\end{array}$ & $\begin{array}{l}\text { Provides funds for prototyping and R and D; } \\
\text { runs a range of supply chain and } \\
\text { diversification initiatives; runs the National } \\
\text { Renewables Infrastructure Funds; interacts } \\
\text { with potential inward investors. }\end{array}$ \\
\hline $\begin{array}{l}\text { Scottish } \\
\text { Renewables }\end{array}$ & $\begin{array}{l}\text { A member-based trade body } \\
\text { representing private firms } \\
\text { and public sector } \\
\text { organisations which } \\
\text { promotes the interests of the } \\
\text { sector to policy-makers. Not- } \\
\text { for-profit. }\end{array}$ & $\begin{array}{l}\text { Liaises closely with the Scottish and UK } \\
\text { governments. Provides intelligence, } \\
\text { reports and industry events. }\end{array}$ \\
\hline
\end{tabular}

\subsubsection{Energy Market Regulation}

As well as funding pilot projects, the NFFO laid the foundations for Renewables Obligation

(RO) that became the principal support mechanism from 2002. The RO placed a mandatory requirement on suppliers to source an increasing proportion of electricity from renewable sources, rising from 3\% in 2002-03 to $14.4 \%$ by 2015-16 (Redpoint Energy 2012: 17).

Following the introduction of banding in 2009, offshore wind developers received 2

Renewable Obligation Certificate (ROC) per MWh of electricity generated relative to 0.9

ROC for onshore wind. This stimulated the rapid expansion of the sector.

After coming to power in 2010, the Conservative-Liberal Democratic Coalition Government launched a process of Electricity Market Reform (EMR) which aimed to ensure a secure 
electricity supply and sufficient investment in low-carbon technologies whilst minimising costs to consumers (DECC 2013). The central component of this is the move away from the RO to a Contracts for Difference (CfD) system. The introduction of CfD can be seen as a key element in the broader institutional 'layering' of the financial support regime for renewable energy in the UK (see Boas 2007; Martin 2010), based on the establishment of new rules, prices and procedures on top of the existing RO system (although this is closed to new entrants from 2017). Under CfD, a competitive auction process is used to award contracts, with applicants receiving the auction 'clearing price' rather than the administrative 'strike price' (DECC 2015). In this respect, EMR can be seen as a liberalisation of the support regime for renewable energy, replacing the $\mathrm{RO}$ with a competitive allocation mechanism.

At the same time, the Coalition Government has also sought to control the overall volume of funding available for renewable energy under the Treasury-agreed Levy Control Framework (LCF). This allocates a finite annual budget for low carbon electricity, rising from $£ 4.3$ billion in $2015 / 16$ to $£ 7.6$ billion in $2020 / 21$, including existing commitments under the RO (DECC 2013: 24-26). The introduction of the LCF represents not only the influence of the government's austerity programme, but also growing concerns about consumer affordability in the wake of the post-2008 economic crisis and rising energy bills prior to late 2014. This reflects the fact that support for renewable energy generation is funded by a surcharge on consumer's bills. This has reinforced the emphasis on cost reduction as the overriding objective of the industry.

The lengthy EMR process was widely seen by the industry as a source of uncertainty, contributing to the cancellation and rationalisation of several offshore wind projects in 201314. Nonetheless, the offshore wind sector was successful in the Final Investment Decision 
Enabling Round held by DECC in 2013-14 to ease the transition to CfD, accounting for five of the eight projects awarded investment contracts. In addition, two offshore wind projects were awarded contracts in the first CfD round held in 2015, with the competitive auction process reducing costs by 18 per cent from the administrative strike price (DECC 2015). The results of a second CfD round were announced in September 2017, with an awarded price of $£ 57.50$ per MW hour for two of the three successful offshore wind projects (BEIS 2017a), representing a 50 per cent fall in price from the 2015 CfD round, reflecting radical cost reduction in the wider industry (GWEC 2017, p.59).

\subsubsection{Industrial policy}

In an attempt to support industrial growth, a series of vertical policy dimensions have been developed to supplement the horizontal emphasis on market support. The publication of the UK Offshore Wind Industrial Strategy (OWIS) in 2013 marked a recognition that industrial development was failing to keep pace with UK's leading market status (BVG Associates 2013). First, with over $80 \%$ of the value of some existing UK installations having been sourced from outside the UK, mostly by Siemens and Vestas in Germany and Denmark, the OWIS was an attempt to improve the levels of domestic content and better "complete the economic circle of benefits to the UK" (OWIC 2014 p. 3). Second, the OWIS was seen as a vehicle to achieve significant cost reduction in offshore wind. Third, it reflected a broader recentralisation of industrial support and economic development in England following the abolition of the nine regional development agencies in 2011.

To achieve a 'competitive and innovative UK supply chain that delivers and sustains jobs' (HM Government 2013 p.7), the OWIS adds the aspiration of generating 50\% of value from domestic content. To help reach this target, industrial support focuses on three areas of 
interrelated activity. First, in the absence of a domestic capacity in turbine manufacturing and related elements of the supply chain, the Offshore Wind Investment Organisation, established by UK Trade and Industry (UKTI), provided a focus for the promotion of FDI and transplantation (Table 5). Second, to stimulate diversification and domestic capacity in the broader balance-of-plant supply chain, the GROW: Offshore Wind organisation was formed to provide grants, assistance and advice for UK firms. Third, inspired by the German Fraunhoffer model of Technology and Innovation Centres (Hauser 2009), over $£ 46$ million of support has been allocated to the formation of an Offshore Renewable Energy (ORE) Catapult Centre to lead on R\&D, testing and cost reduction strategies (Table 5). Based in Glasgow, the centre also includes world-leading test facilities and demonstration sites in the North East of England originally developed by the former regional development agency, One North East.

\subsubsection{Spatial policy and planning}

The planning regime for offshore wind in the UK is generally more centralised than that for onshore wind, with the increased co-ordination of a previously fragmented and complex process having granted approval powers to central government departments and agencies. In England, offshore wind projects of more than $100 \mathrm{MW}$ (virtually all) are now assessed by the Planning Inspectorate - an executive agency of the Department for Communities and Local Government - following the abolition of the Infrastructure Planning Commission in 2012, with the final decision on approval being taken by the Secretary of State for Business, Energy and Industrial Strategy. In Scotland, projects are assessed by Marine Scotland, a department of the Scottish Government, with decision on approvals taken by Scottish Ministers, in effect the Minster for Business, Innovation and Energy. 
The centralisation of the planning process is generally associated with a high proportion of approvals with the overwhelming majority of offshore wind projects having been granted consent (Renewable UK 2014: Toke 2011). In general, the UK has adopted a criteria-based planning approach for both onshore and offshore wind whereby applications are assessed against various standards, largely environmental and safety, rather than a spatial zoning strategy (Toke 2011). More broadly, in contrast to Germany, Denmark and the Netherlands shifting towards a state-led centralised model of development, the UK continues to pursue the developer-initiated approach whereby developers take on the costs and risks associated with securing a seabed lease and progressing the project through the planning and consenting processes independently, including the cost of grid connection, before even entering the auction process for subsidy. The externalisation of such development expenditure can exceed over $£ 50 \mathrm{~m}$ per project and therefore continues to favour large utility companies able to accommodate create high-barriers of entry in advance of consenting (4cOffshore 2017).

\subsection{Firms, FDI and branching}

Whilst the UK state has played a pivotal role in the development of the UK's offshore wind market, industrial development has been structured by the relative dominance of multinational lead firms, suppliers and competences from the historical heart of the industry Germany and Denmark. Emerging from the privatisation process in the 1990s, the UK energy generation and supply system has become highly concentrated and internationalised in its ownership structure, reflecting the operation of an 'outside-in' mode of investment based on the take-over of domestic companies by foreign firms (see Sadler 2001). This underpins the highly corporate structure of the offshore wind industry in the UK, dominated by large energy utilities and overseas-based turbine manufacturers and suppliers. 
In manufacturing, this has fostered a dependence on the attraction of FDI rather than branching and indigenous creation. Almost the entire capacity of the UK market has been installed using turbines produced and assembled in Germany and Denmark. No UK headquartered firms produce offshore wind turbines and the last turbines to be assembled in the UK were a small project by Vestas in 2004.

Consequently, attracting the 'holy grail' of a focal firm in turbine manufacture to the UK has been seen as a critical to stimulating a broader domestic supply chain (Shepherd Offshore, Authors' Interviews 2012). Prior to the development of the OWIS, inter-territorial competition between a number of English regional development agencies and Scottish Enterprise led to a raft of memorandums of understanding (MoU) being agreed with turbine manufacturers such as Areva, Gamesa and Samsung (Scotland) and Clipper Wind (Newcastle) and Siemens (Hull). As uncertainty increased around EMR and the Coalition Government's political commitment to offshore wind, however, only Siemens progressed to investment. As such, earlier optimism appears to have superseded by the realisation that the UK's revised market projections, coupled with Siemens' dominance of the offshore market, is unlikely to provide the levels of demand necessary to attract further turbine manufacturers to the UK (BVG ASSOCIATES 2017; Authors Interview 2014).

Elsewhere in the manufacturing supply chain, whilst a few UK firms have produced towers for smaller onshore turbines, there is limited potential to diversify and upscale into the relatively mature and cost-sensitive commodity market of tower production (BVG Associates 2014). In tower manufacture, the only UK-based investment to date has been South Korea's CS Wind's 2016 acquisition and diversification of former onshore manufacturer Wind 
Towers (Scotland) in Campbeltown, Scotland. In terms of foundation structures, although a small number of UK firms have diversified from the oil and gas $(\mathrm{O} \& \mathrm{G})$ industry, market penetration has been limited by the relatively low costs of transferring and installing monopiles from the established market leaders in the Netherlands (e.g. Sif and Smulders), Germany and Denmark (e.g. EEW and Bladt).

UK manufacturers have been most successful in diversifying into substations and cables. Around $70 \%$ of the UK market for substation fabrication and installation has been delivered by UK based operations (albeit many with headquarters overseas), including ABB, Alstom, Siemens and Petrofac in electrical systems and firms such as BiFab, Harland and Wolf and Heerema in fabricated structures (BVG Associates 2014). The success reflects a combination of the unique electrical standards in the UK, and the experience of producing similar structures for the O\&G sector. Similarly, JDR cables have diversified from producing umbilical cables for the $O \& G$ market to become an exporter of array cables to offshore wind markets. In summary, prior to the major stimulus of the Siemens investment, the UK's development into manufacturing production networks remain limited.

In contrast, and indicative of the importance of geographical proximity and access to the wind farms, $90 \%$ of the UK's offshore employment takes place in deployment activities (Renewables UK 2013). At the heart of the deployment chain, the development and ownership of the UK's wind farms remains dominated by a small range of multinational energy firms and utilities such as E.ON, RWE (Germany); DONG (Denmark); Statkraft and Statoil (Norway); Vattenfall (Sweden); Iberdrola (Spain) as well as the UK-based Centrica and SSE. Construction and installation is the largest employer in the deployment chain, 
covering 1 in 3 jobs, but remains very episodic and is based upon the temporary assembly of workers, skills and equipment on a project by project basis.

Almost all O\&M activities are currently undertaken from UK ports. Transplantation has again served as the central mechanism with inward investors becoming the largest employers (e.g. Siemens; DONG), albeit alongside UK firms such as Centrica. Diversification has mostly been limited to activities contracted out by the developers, allowing some transfer of competences from the $\mathrm{O} \& \mathrm{G}$ sector (e.g. vessel manufacture; personnel transfer; minor servicing etc.). Whilst O\&M represents around 1 in 5 of windfarm employment, $27 \%$ of the lifetime costs of a windfarm and $70 \%$ of person hours, the seasonal nature of work and modest levels of capital required provide a relatively lower level of value capture and growth opportunities for host localities (Renewables UK 2013). In addition, technological change and the move to 'bigger, deeper, further' (EWEA 2011) from shore farms threaten to centralise $\mathrm{O} \& \mathrm{M}$ activities in a smaller number of ports, in contrast to the dispersed pattern that has characterised the industry thus far (BVG Associates 2017)

\subsection{Creating regional growth paths}

\subsubsection{Geography of OW development}

The geography of UK offshore wind industrial development reflects closely the geography of installed capacity which focuses on three strategic areas: Greater Wash, Greater Thames and Irish Sea (Figure 8). As a consequence, locations such as the North East of England and Scotland which developed pioneering R\&D and industrial development initiatives (Dawley et al 2014), have since been overtaken by locations benefiting from closer proximity to the evolving geographies of Rounds 1, 2 and 3 installations. O\&M and deployment activities 
have so far dominated, creating a number of geographical concentrations of activity in East Anglia, Humber and Barrow-in-Furness (OWIC, 2014). Following the abolition of Regional Development Agencies in England, much of the local institutional support for economic development in the industry has been left to the new patchwork of Local Enterprise Partnerships covering smaller geographical areas and operating with substantially fewer resources (Pike et al 2015).

The remainder of this section explores the processes of path creation in these varied governance contexts by focusing on Scotland and Humberside. Scotland, has evolved into is the leading region within the UK for the development of a broad base of renewable energy, reflecting its possession of abundant natural assets and the strong political commitment and institutional support of the Scottish Government. Humberside, in contrast, with relatively limited local and regional institutional capacity has more recently become the UK's focal point of offshore wind development by capturing the UK's largest offshore wind FDI project.

Figure 8: Offshore wind farms in the UK - October 2014

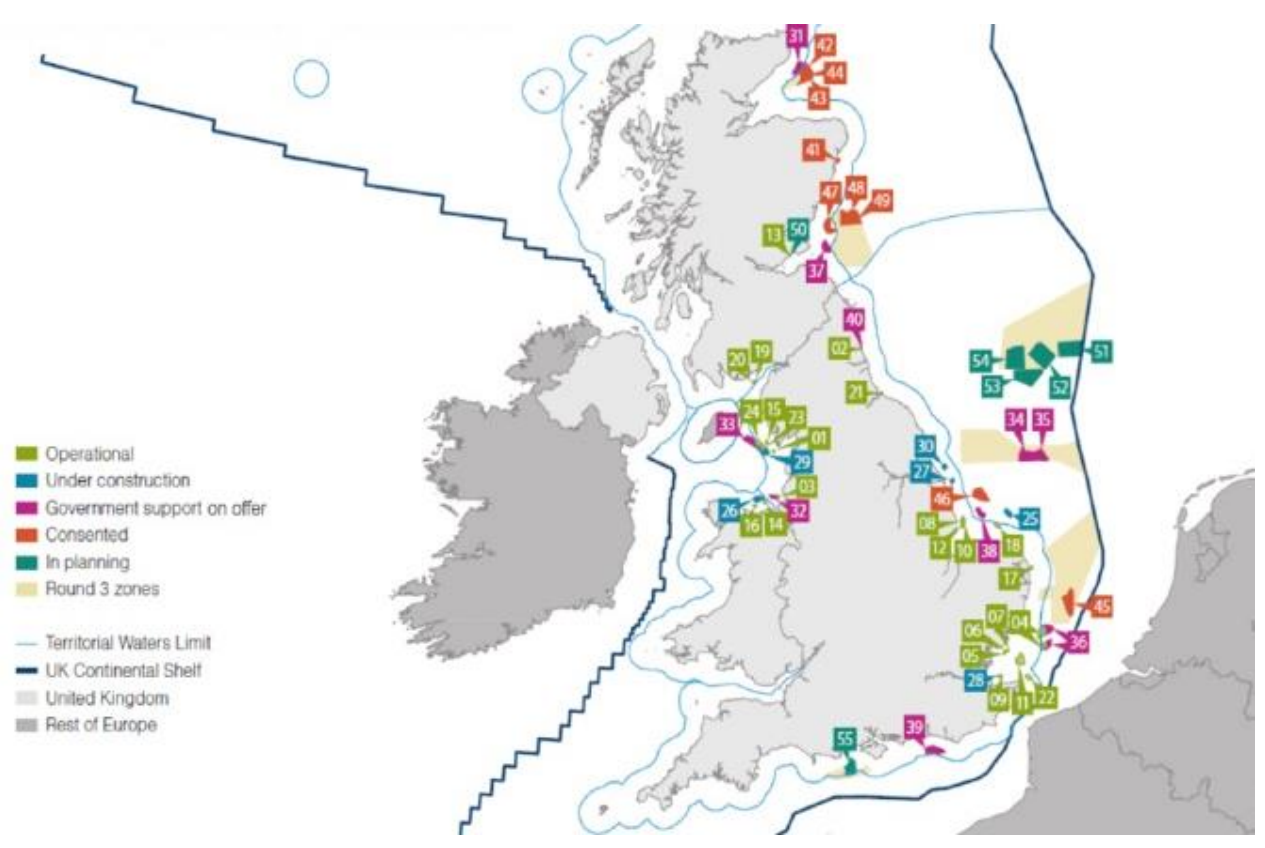


Source: UK Trade \& Investment et al. 2014: 7

\subsubsection{Scotland}

Under the UK model of asymmetrical devolution, the SG has the power to set its own renewables targets and to control the planning process for renewables, although the financial support regime is reserved to the UK government (Cowell et al. 2015; see also Table 5). It has set some of the most challenging targets in Europe, namely the generation of 100 per cent of its electricity needs from renewables by 2020, compared to the UK target (which it contributes towards) of 30 per cent. Partly as a result, renewable energy generation has expanded considerably from 12.2 per cent of electricity consumption in 2000 to 54 per cent in 2016 (BEIS 2017c, p.71), with wind growing from 308 MW in 2003 to almost 6,462 MW by 2016, almost all of which is from onshore sources (BEIS 2017b, p.66). By contrast, offshore wind has been slower to develop, reflecting the difficulties and higher costs of offshore deployment in deeper waters and more exposed seas, with one large and two demonstration projects under construction and two further larger projects having gained CfD funding, one of which has been delayed by a planning objection.

At the same time, Scotland has had considerable success in attracting and developing a number of strategic $R \& D$ projects in offshore renewables, providing a basis for path creation. For example, the International Technology and Renewable Energy Zone (ITREZ) has been established as "a global R and D hub" in Glasgow, building on the presence of two of the "big six' UK energy companies (Scottish Power and Scottish and Southern Energy). The ITREZ also incorporates the ORE Catapult Centre established by the UK government. In addition, 
Edinburgh won the bid to host the headquarters of the Green Investment Bank which became a major investor in offshore wind projects prior to its sale.

More recently, in a further example of enhanced institutional capacity and strategic vision in offshore wind, Scotland negotiated an extension of the UK's RO subsidy system to support targeted R\&D and demonstration projects. Until September 2018, Scotland is able to offer RO subsidies at a band of 3.5 ROCs for pilot projects focused on floating technologies. As a result, Statoil's investment in the Hywind pilot project near Aberdeen has created the world's largest floating wind farm and pioneering demonstration project. In this context, Scotland has successfully competed for both public-funded facilities from the UK government and R and D investment from lead firms in offshore wind production networks, although much of this private investment has been curtailed as the institutional and political environment for offshore wind became more constrained under CfD and the LCF (Latham 2015). These successes reflect Scotland's institutional advantage over English regions like the Humber, manifest in the role of the devolved SG and its long-established regional development agencies (Scottish Enterprise and Highlands and Islands Enterprise) (Table 5).

Path creation in offshore wind manufacturing has been less successful. While the SG signed MoUs with the turbine manufacturers Gamesa, Areva and Samsung to establish factories in Scotland, these plans have now been dropped as size of the UK market has become more limited (Latham 2015). With the exception of the CS Towers acquisition in Campbeltown, diversification has been limited. In particular, expectations of branching from the O\&G sector were initially hampered by the buoyant nature of this sector, only for the recent fall in oil prices to be negated by the increased uncertainty surrounding offshore wind (authors' interviews 2014). This prompted some attrition in the offshore wind sector in Scotland with 
developers cancelling or scaling back their investment in several projects in 2013-2014, although two Scottish projects were awarded contracts under the transitional arrangements and first CfD allocation round.

\subsubsection{Humberside}

By securing Siemens' flagship investment in 2014, Humberside has moved from a reactive latecomer in offshore wind development to become its leading production and deployment centre. In contrast to the proactive strategies of development agencies in Scotland and North East England, Humberside's emerging path has been forged by the market selection processes of lead firms and their strategic partners seeking out two sets of assets. First, the natural asset of the Humber's proximity to the market (with $80 \%$ of North Sea wind zones within 12 hours steaming time). Second, the infrastructural assets of the scale and availability of port related facilities, with many of them rendered redundant by the decline of the fishing industry. National and local policy actors have subsequently responded to, rather than stimulated, a series of parallel and overlapping processes of path creation.

First, the process leading to Siemens investment on the Humber began in 2010 when the firm signed a MoU with the UK government. In 2011 Hull was chosen as Siemens' preferred site, based upon the unique scale of the port infrastructure available and the pledge by ABP, the port's private sector owner, to invest $£ 100 \mathrm{~m}$ in the conversion of the Alexandra Dock. The lead time for the development of the Hull site was also much shorter than the planning process for a greenfield site, as the Council had submitted a port revision order prior to Siemens' interest, enabling it to secure approval for the amendment of this order from national government (authors' interviews 2012, 2015). UK government support was made 
available by designating the site as an Enterprise Zone, allowing enhanced capital allowances and tax benefits.

However, despite being heralded as "a new era" for Hull as a "world leader in offshore wind" by Prime Minister David Cameron (cited in Hull Daily Mail 2011), Siemens took three years before it confirmed its final investment decision. Demonstrating the importance of multiscalar institutional and political contexts to regional path creation, the perceived weakening of the Coalition Government's commitment to renewable energy and uncertainty over EMR "caused huge concern in Berlin" and the prospect of a move to an alternative site in Germany or Denmark in 2012 (Allan Johnston MP cited in Clark et al. 2014) before Siemens finally confirmed its $£ 160$ million investment in Hull and the creation of 1000 direct jobs in 2014. Even then, the character of Siemens eventual investment became modified to focus solely on the production of blades with the higher-value task of nacelle assembly instead shifting to the Siemens' new operation in Cuxhaven, Germany (authors' interviews 2017).

Second, the former fish docks in Grimsby have become host to a series of lead firms in the deployment chain. Since 2012, investments from firms such as Centrica ( $£$ 3.6m), EON ( $£ 4$ million) and most recently DONG ( $£ 12$ million) have targeted Grimsby’s available port infrastructure and proximity to existing Round 1 and 2 wind farms as sites for North Sea O\&M bases. These investments have stimulated a series of local firms to diversify to serve as contractors, ranging from vessel transfer to marine engineering. Although firms such as DONG have stated a 25 year commitment to service their Round 2 sites from Grimsby, the overall impact of O\&M on the local economy remains relatively limited with modest levels of direct employment (300-500) to date. 
Third, Able UK, a private port operator is developing a large 320 hectare deep water facility and industrial park at Immingham on the south bank of the Humber with the aim of attracting a cluster of manufacturing and O\&M operations. The $£ 450$ million project, supported by $£ 15$ million of UK government grants and Enterprise Zone status, is 60\% larger than Europe's leading offshore wind industrial site at Bremerhaven. To date, however, no firms have committed investment to the site, achieving only preferred site status for Strabag's (Austria) production of concrete gravity bases.

\subsection{Summary}

In overall terms, the development of offshore wind in the UK can be characterised as a market-led process whereby the rapid expansion of the market in the 2000s has prompted a series of subsequent initiatives to promote industrial and territorial development. Limited success in R\&D-based initiatives and branching strategies means transplantation has become the dominant mechanism of path creation. As a result, the UK is developing new forms of strategic coupling around lead firms in O\&M and the deployment chain, with emerging but constrained development in manufacturing, particularly in terms of the Siemens investment in Hull and the decision by Vestas (now MHI Vestas) to reopen and convert its former Isle of Wight blade factory from onshore to offshore technologies. The MHI Vestas case provides a rare example of industrial branching between the onshore and offshore sectors in the UK. Instead, the main areas where diversification and industrial branching have supported path creation involve technologies and infrastructures from the $O \& G$ and marine fabrication related sectors. 
The local and regional development effects of offshore wind development have been highly uneven with functional divisions of labour emerging between pioneering regions such as Scotland and North East England, where a policy-led approach had had some success in establishing and attracting R and D and test facilities (particularly in the former), and latecomer sites of industrial development, principally Humberside. The emergence of these latecomer regions highlights the importance of geographical proximity to offshore installations and the availability of large-scale infrastructure in shaping the market selection of lead firms and their strategic partners, with local institutions subsequently responding to meet the strategic needs of such firms. As emphasised above, the envisaged scale of the UK market has been reduced somewhat under CfD and the LCF, triggering some concerns that Germany or even China could threaten its dominance of the sector (Clark 2015). However, given the magnitude of recent cost reductions, and the emerging prospect of a subsidy-free industry, the UK market may yet enter a new phase of dynamic growth (authors' interview, 2017).

\section{Path Creation in Offshore Wind: the case of Norway}

\subsection{Origins and development path}

Norwegian firms, such as Nexans (offshore cable supply and installation services) and DNV $\mathrm{GL}^{1}$ (certification services), have been involved in the offshore wind sector since the first farms were developed in Denmark in the early 1990s. Although the Norwegian offshore wind industry is still in an embryonic phase, the industry is a target area in the national strategy for development of renewable energy (ENERGI21 2014), and has been referred to as Norway's potentially "next industrial adventure" (Hansen and Steen 2011). In stark contrast to the UK,

\footnotetext{
${ }^{1}$ Det Norske Veritas: DNV was the Norwegian predecessor of the classification society DNV GL, merged in 2013
} 
and Germany, however, Norway does not have a domestic market for offshore wind. Nor is it likely that large scale offshore wind farms will be developed in Norway in the period towards 2020, despite its possession of vast offshore wind resources (NVE 2012).

In addition, to understand the apparent paradox between a weak domestic market on the one hand and articulated industrial ambitions on the other, we have to consider offshore wind relative to Norway's existing natural asset base in terms of hydropower and oil and gas $(\mathrm{O} \& \mathrm{G})$. After emerging in the early twentieth century, hydropower became the nation's dominant source of electricity (Figure 9) (Rusten 2013). Today, even though Norway possesses the second highest per capita rate of electricity consumption in the world, this demand is covered entirely by hydropower.

Second, Norway's natural resource endowment of O\&G allowed its offshore extraction to develop into the country's largest and most knowledge intensive sector. Norway is now a significant exporter of O\&G to the world market, as well as an exporter of offshore technology and solutions. More recently, many O\&G suppliers have internationalized, and state-owned Statoil has become a global corporation with operations on all continents. Together, the established $O \& G$ and the hydropower industries have been highly influential in shaping the landscape for energy production and industrial development (Cetkovic et al. 2016). They provide a basis of industrial and human assets with the potential for branching into offshore wind. 
Figure 9: Norwegian power production and balance of trade 1990-2012.

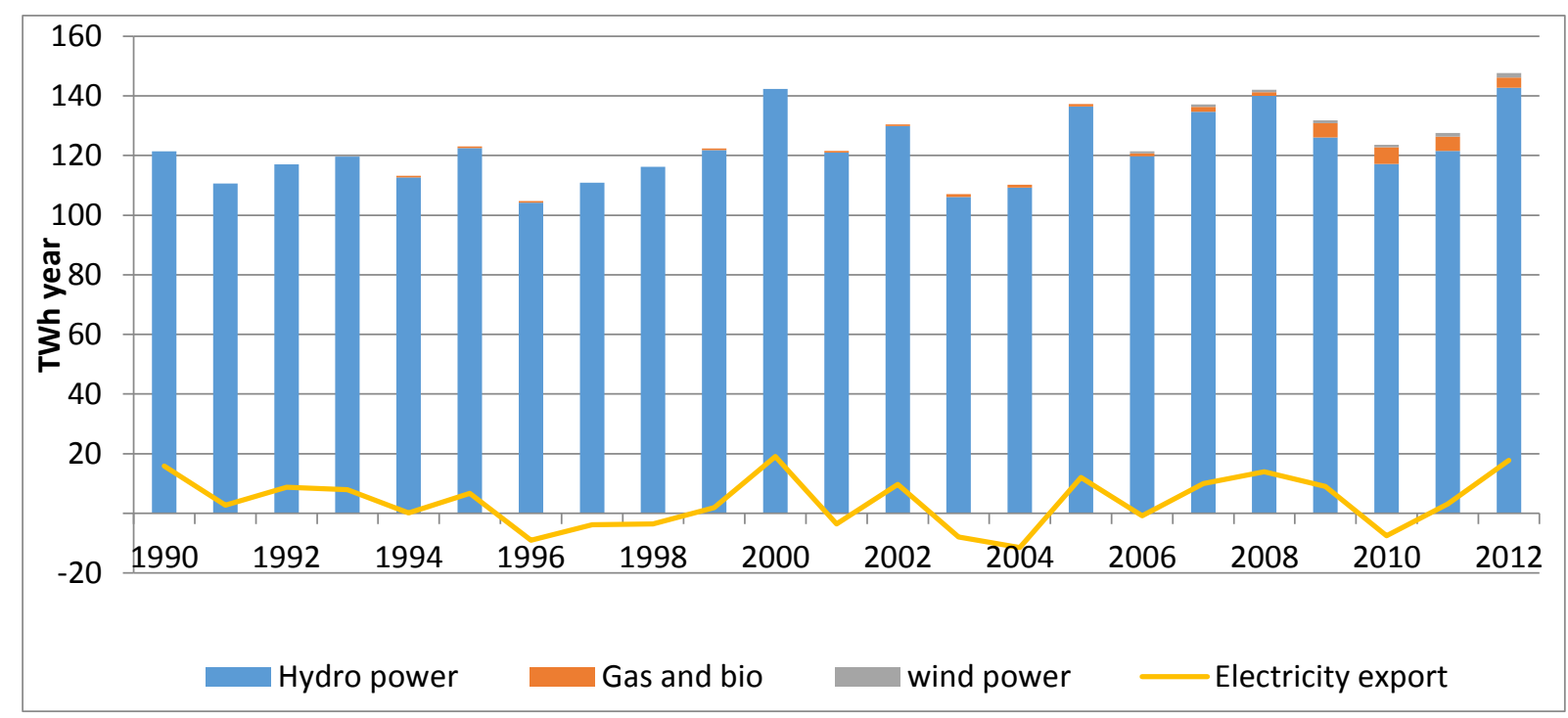

Source: Statistics Norway.

Against this backdrop, Norway became one of the first Western countries to liberalize its electricity market in 1990, paralleling the UK experience of privatisation. A subsequent policy focus on achieving higher rates of cost-efficiency has successfully lowered electricity prices (Wicken 2011). This shift has also led to a sharp reduction in investments in new power production capacity (especially state-led), however, and thus fewer growth opportunities in the domestic market. Indeed, many Norwegian utilities and technology suppliers turned to international markets and invested in energy projects abroad following domestic market liberalisation.

At the same time, energy security emerged on the energy policy agenda as growth in domestic electricity consumption led to Norway becoming a net importer of electricity at certain points in the 1990s (Figure 9) (NOU 1998: 11). In 1999 the government introduced a target for (onshore) wind power of 3TW (3000 GW) by 2010. The main instrument for achieving the goals was the government agency Enova, established in 2001 (Table 6). 
Supporting the development of a Norwegian wind power industry in this period was not, however, considered important by the government (Buen 2006). Despite the articulated ambitions, local resistance (Solli 2010), weak and unpredictable policy instruments and low electricity prices resulted in the slow growth of wind energy. In addition, the high costs of offshore wind development in Norway due to its deep waters and exposed coasts have constrained its growth.

The first discussions of a domestic offshore wind market came around the turn of the millennium, when electrification of offshore $O \& G$ installations entered the Norwegian climate debate. By the mid-2000s, several large utilities and firms from the O\&G industry had become involved in offshore wind. In 2007, Norway's state owned utility Statkraft (the largest producer of renewable energy in Europe) launched a plan to develop a large scale 1000 MW offshore wind farm in Norway by 2012. Moreover, the 'take-off' of the Northern European offshore wind market and the growing levels of complexity involved in developing wind farms in deeper waters, led to an increase in involvement from Norwegian O\&G firms looking to transfer existing offshore competences into the emerging market (Steen and Hansen 2014). The 'bigger, deeper and further' trend in offshore wind development (EWEA 2011) implied an opportunity for industrial assets in O\&G to diversify and support a new path of industrial growth.

Steen (2016) estimates that up to 200 Norwegian firms are (or have been) involved in this emerging industry to larger or lesser extent. The Norwegian sector comprises a small number of (20-25) specialized offshore wind firms, energy majors Statoil (O\&G) and Statkraft (utility) and a broad set of diversified supplier firms from the offshore O\&G, maritime and power/utility sectors. Most of these firms are found in the deployment chain of the OWP 
industry (e.g. foundation structures, maritime logistics, installation) reflecting the knowledge base in the Norwegian petro-maritime industries. Indeed, Norwegian firms such as Statoil and Statkraft have since become lead firms in the development and deployment of offshore wind farms in leading markets such as the UK through an 'inside-out' mode of investment. Furthermore, a range of firms have developed key roles in the offshore installation, foundation and sub-sea segments of global production networks. Apart from a few demonstration/pilot projects and feasibility/concept studies in Norway, however, all these activities are taking place in overseas markets.

\subsection{State Policy}

Offshore wind was not considered as a policy option in the Norwegian energy and climate debate in the early 2000s. However, increased pressure on government to 'act on climate change', growing European ambitions for offshore wind, and a policy shift from costeffectiveness to a degree of technology optimism (Tellmann 2012) opened a window of opportunity for offshore wind in 2007. The Minister of Petroleum and Energy at the time was very enthusiastic about supporting offshore wind not only as an energy and climate measure, but also increasingly from an industry development perspective (Normann 2015). The Government appointed an 'Energy Council' to assess the value and costs of developing offshore wind in Norway. The Energy Council recommended adding 40 terawatt hours (TWh) (equal to approximately $5.76 \mathrm{GW}$ of power per year) of new renewable energy in Norway by 2020-2025, of which roughly half should be provided by offshore wind. This would require a minimum of 3-5 large offshore wind farms (Energirådet 2008). 
The government also asked for recommendations from a separate commission (Energi21) on non-fossil energy related research. In their first report, the commission identified offshore wind as a technology that should be prioritized in energy related R\&D programs (Energi21 2008). Both the Energy Council and Energi21 stressed the relevance of offshore wind amongst the emerging renewable energy technologies given Norway's strong industrial foundations from the offshore and maritime industries. Despite the enthusiasm for offshore wind as a promising industrial opportunity, however, no clear strategic vision of its role in the energy system and how to develop the industry was set out. Apart from the recommendations from the Energy Council in 2008, no specific targets for offshore wind production capacity have been established in Norway. The failure to create a domestic offshore wind market echoes the broader tendency for radical innovation to be restrained by the consensual relations between established stakeholders within a 'simple' CME (Cetkovic et al. 2016).

Following the global financial crisis in 2008 and a major drop in oil prices in 2009, there was a decline in oil investments with layoffs in the oil service sector. Offshore wind thus entered the Norwegian 'life after oil' discourse. For instance, Reve and Sasson $(2012,190)$ argued that "through its broad experience in energy and offshore industries, Norway has unique competencies on which it could establish a leading position in offshore wind power" (authors translation). This line of reasoning has been reflected in numerous policy documents, energy strategy documents and industry reports. The debate on offshore wind thus became part of a wider discourse on the restructuring process of the petro-maritime industry, and on path creation through diversification of firms from the $O \& G$ and maritime industries into emerging industries such as offshore wind. 
In addition to the industrial development argument, offshore wind has been seen as an opportunity for supplying both domestic (including offshore O\&G installations) and neighboring markets with clean electricity, as well as a way of solving regional energy shortages. The lack of sufficient financial subsidies has, however, hampered investment in offshore wind farms in Norway.

\subsubsection{Energy Market Regulation}

Following a compromise agreement in Parliament (the 'Climate Agreement') in January 2008, the debate about whether Norway should join the Swedish Electricity Certificate Market (ECM) became more salient. The 'Climate Agreement' outlined the national strategy for the energy sector, including the exploitation of maritime energy sources (wind, wave and tidal). Climate change was high on the public agenda, promoting the government to act. Thus, even though subsidizing selected technologies ${ }^{2}$ worked against principles of cost-efficiency (Normann 2015), joining the ECM made sense as a political strategy (Boasson 2011). A strong lobby that included the major utilities and the Norwegian Wind Energy Association (NORWEA) supported the certificate market (former State Secretary, Ministry of Petroleum and Energy, authors' interview).

In contrast to instruments such as feed-in tariffs, which have offered enhanced support to offshore wind in Germany under the RESA, and the banding of the RO in the UK from 2009, the ECM is technology neutral and supports all technologies that are included in the agreement with the same amount per KWh produced. As such, the ECM favours mature technologies such as hydro and onshore wind power, and is not sufficient in order to spark

\footnotetext{
${ }^{2}$ Large hydropower was excluded from the scheme.
} 
production capacity investments into less mature and more costly technologies such as offshore wind (Bergek and Jacobsson 2011). When the ECM agreement was finalized in 2009 , it became clear that it would not contribute to realizing full-scale offshore wind in Norway. In this crucial sense, then, Norway must be seen as a constraining institutional environment for the development of offshore wind compared to the UK and Germany.

\subsubsection{Industrial policy}

Energy and climate policies in Norway have been guided by a principle of cost-efficiency and an unwillingness to develop market support mechanisms for immature technologies. There has been an increased willingness in recent years, however, to focus R\&D funding on particular technologies in which Norway has a relevant resource base (both knowledge, industrial capacity and natural resources) such as offshore wind, CCS and solar. This has been manifested notably through R\&D policy (see Table 6), but a downturn in the O\&G sector in 2009 also spurred a number of spatial policy measures, which recast the framing of offshore wind from an 'energy production' perspective to an industrial development perspective (i.e. as a branching opportunity for the $\mathrm{O} \& \mathrm{G}$ sector).

Table 6: Main institutional actors in the case of Norwegian offshore wind

\begin{tabular}{|l|l|l|}
\hline $\begin{array}{l}\text { Institutional } \\
\text { actors }\end{array}$ & Main function & Role/activities in offshore wind \\
\hline GIEK & $\begin{array}{l}\text { Public enterprise mandated to issue } \\
\text { financing, guarantees and insurances } \\
\text { in order to stimulate the export of } \\
\text { Norwegian goods. }\end{array}$ & $\begin{array}{l}\text { Has supported various firms, e.g. } \\
\text { lenders guarantee worth 70 MEUR to } \\
\text { the Norwegian delivery of sub-sea } \\
\text { cables to the Belgian offshore wind } \\
\text { farm Belwind. }\end{array}$ \\
\hline Intpow & $\begin{array}{l}\text { Nonprofit joint venture between } \\
\text { industrial actors and the Government }\end{array}$ & $\begin{array}{l}\text { Organizes and coordinates } \\
\text { conferences, networking events and }\end{array}$ \\
\hline
\end{tabular}




\begin{tabular}{|c|c|c|}
\hline & $\begin{array}{l}\text { facilitating the networking and } \\
\text { internationalization process of } \\
\text { Norwegian renewable energy firms. }\end{array}$ & $\begin{array}{l}\text { business tours. Maintains the } \\
\text { Norwegian offshore wind supplier } \\
\text { database. }\end{array}$ \\
\hline Enova & $\begin{array}{l}\text { Public enterprise mandated to } \\
\text { stimulate the transition to more } \\
\text { environmental friendly energy } \\
\text { consumption and generation in } \\
\text { Norway. }\end{array}$ & $\begin{array}{l}\text { Supports demonstration and } \\
\text { development projects in offshore } \\
\text { wind. Enova's total support to } \\
\text { offshore wind is estimated to be } 245 \\
\text { million Norwegian Krone (MNOK). }\end{array}$ \\
\hline $\begin{array}{l}\text { Innovation } \\
\text { Norway (IN) }\end{array}$ & $\begin{array}{l}\text { Public agency aiming to stimulate } \\
\text { innovation and internationalization in } \\
\text { Norwegian companies and industries. }\end{array}$ & $\begin{array}{l}\text { Has granted } 126 \text { MNOK to various } \\
\text { projects related to offshore wind } \\
\text { development programmes since } 2008 \text {. } \\
\text { Manages the 'Arena programme', } \\
\text { which offers financial and other forms } \\
\text { of support towards the development } \\
\text { of regional clusters. Two Arena } \\
\text { projects have focused on offshore } \\
\text { wind (Windcluster Mid-Norway and } \\
\text { Arena NOW). }\end{array}$ \\
\hline $\begin{array}{l}\text { The Research } \\
\text { Council of } \\
\text { Norway (RCN) }\end{array}$ & $\begin{array}{l}\text { The national strategic and funding } \\
\text { agency for research activities in } \\
\text { Norway, managing a budget of } 7377 \\
\text { MNOK (2013). }\end{array}$ & $\begin{array}{l}\text { Funds the renewable energy research } \\
\text { programme EnergiX and two } \\
\text { innovation-oriented Centres for } \\
\text { Environment-friendly Energy Research } \\
\text { focusing on offshore wind NOWITECH } \\
\text { and NORCOWE). Total funding to } \\
\text { offshore wind since } 2008 \text { estimated to } \\
364 \text { MNOK. Also partner in the Arena } \\
\text { programme. }\end{array}$ \\
\hline SIVA & $\begin{array}{l}\text { Public enterprise aiming to facilitate } \\
\text { regional and local industrial clusters } \\
\text { by investing in companies, } \\
\text { infrastructure, and facilities such as } \\
\text { industry incubators. }\end{array}$ & $\begin{array}{l}\text { Invested } 120 \text { MNOK in an offshore } \\
\text { wind production site (Verdal) in } 2010 . \\
\text { Also partner in the Arena programme. }\end{array}$ \\
\hline $\begin{array}{l}\text { Norwegian } \\
\text { Water } \\
\text { Resources and } \\
\text { Energy } \\
\text { Directorate } \\
\text { (NVE) }\end{array}$ & $\begin{array}{l}\text { Government directorate under the } \\
\text { Ministry of Petroleum and Energy. } \\
\text { Responsible for safe and sound } \\
\text { management of water and energy } \\
\text { resources. }\end{array}$ & $\begin{array}{l}\text { Licensing authority responsible for } \\
\text { permissions to build and operate } \\
\text { energy production installations. Co- } \\
\text { authored the Offshore Wind Strategic } \\
\text { Environmental Assessment (SEA) with } \\
\text { the Norwegian Environment Agency } \\
\text { in } 2012 \text {. }\end{array}$ \\
\hline $\begin{array}{l}\text { Norwegian } \\
\text { Environment } \\
\text { Agency (MD) }\end{array}$ & $\begin{array}{l}\text { Government directorate under the } \\
\text { Ministry of Climate and Environment. } \\
\text { Works towards reducing climate gas } \\
\text { emissions and pollution, as well as } \\
\text { protection of landscapes and } \\
\text { biodiversity. }\end{array}$ & $\begin{array}{l}\text { Advisory body safeguarding } \\
\text { environmental concerns (birdlife, } \\
\text { landscape etc.). Co-authored the } \\
\text { Offshore Wind Strategic } \\
\text { Environmental Assessment (SEA) with } \\
\text { NVE in } 2012 \text {. }\end{array}$ \\
\hline
\end{tabular}


The main financial support for offshore wind in Norway has been through R\&D funding. Following the 2008 'Climate Agreement' in Parliament, eight Centers of Environmentalfriendly Energy Research ('FME') were established in 2009 (lasting eight years), of which two (NOWITECH and NORCOWE) target offshore wind. A second outcome of the 'Climate Agreement' was the decision to direct 150 million Norwegian Krone (MNOK) to the establishment of an Energy Fund, managed by Enova, for the development and testing of new renewable energy technologies. In 2007, Enova provided 59 MNOK to the world's first floating wind turbine (Hywind demonstration) developed by Statoil. Increased allocations to the Energy Fund in 2008 and 2009 provided additional funding for testing and demonstration of prototypes. While this R\&D investment is designed to have an enabling effect, it is outweighed in practice by the absence of the financial support required to create a domestic market.

In the autumn of 2009, two regionally based cluster initiatives were funded through the Arena programme, which is jointly financed by the three key institutional actors IN, RCN and SIVA (see Table 6). These regional initiatives were both linked to the reorientation of regional O\&G industry paths that were seen to be on the decline (Isaksen 2014). Reflecting fading expectations related to the formation of a large-scale domestic offshore wind market, however, by 2010 the policy debate focused on the potential for 'onside out' strategies to develop and position the supplier industry within emerging global production networks for overseas markets (Hansen and Steen 2011).

At the same time, a range of stakeholders in industry and R\&D voiced the need for public funding of full-scale demonstration projects to catalyze industrial development in offshore wind in Norway. Our interviews revealed a general agreement in the industry that some form 
of domestic market is needed to stimulate the mechanisms through which $\mathrm{O} \& \mathrm{G}$ competence and assets can branch into and help create an offshore wind industry focused on export markets. Several firms (particularly SMEs) that have developed new solutions for offshore wind point out that it is very difficult to enter foreign markets without experience and 'verified' technology (Steen and Hansen 2014). To date, however, Norwegian state-led approaches to renewable energy have prioritized technology-push type public R\&D projects, whereas support for upscaling and commercialization and general market creation remains underplayed (Wicken 2011).

\subsubsection{Planning regime and spatial policy}

A durable tradition for regulating domestic natural resources has prevailed in Norway since the exploitation of hydro power became tightly regulated through the Concession Act in 1911. Within a licensing system, applicants had to specify how their activities would support domestic interests (Engen, 2009). This approach informed the regulation of the petroleum industry emerging in the 1970s (Sæther et al. 2011). Basically any offshore wind activity on the Norwegian Continental Shelf (NCS) has to comply with existing licencing systems.

In June 2009, the Norwegian Maritime Renewables Act (MRA) was adopted in Parliament, providing the legal basis for the development of offshore wind power in Norway. Similar to the FMEs and the EMC scheme, the MRA had its background in the Parliamentary 'Climate Agreement' in 2008. Following the development of the MRA, the Ministry of Petroleum and Energy appointed a group of state Directorates led by NVE (Table 6) to conduct a Strategic Environmental Assessment (SEA) for offshore wind in 15 identified areas (NVE 2010). Based on an assessment which included environmental concerns, industry and public 
interests, as well as wind resources and technical feasibility, the SEA (NVE 2012) identified five offshore wind zones as technically/economically feasible and environmentally acceptable (Figure 10).

Table 7 lists Norwegian offshore wind projects that have aimed for a license for development. Only one full-scale project has received a license (Havsul I). Two large projects have been rejected, while one (Siragrunnen) is currently subject to an appeal. The other projects have, for various reasons, not been through the full license evaluation.

Table 7: Offshore wind projects in Norway

\begin{tabular}{|l|l|l|l|}
\hline & Projects & Installed capacity & Notes \\
\hline In operation & 1 & $2,3 \mathrm{MW}$ & Hywind, one single floating turbine \\
\hline Licence granted & 8 & $420 \mathrm{MW}$ & $\begin{array}{l}\text { Havsul I (350MW) + seven 10 MW } \\
\text { demo sites. One appeal }\end{array}$ \\
\hline Applications & 9 & $3566 \mathrm{MW}$ & $\begin{array}{l}\text { NVE has requested the withdrawal } \\
\text { of some applications }\end{array}$ \\
\hline Applications rejected & $2(3)$ & $1150(+200) \mathrm{MW}$ & Two projects finally rejected, one \\
(Siragrunnen) appealed
\end{tabular}




\subsection{Firms, FDI and branching}

Industrial branching or diversification is the central mechanism driving Norway's growth path in offshore wind. Stretching back to the early 1990s, Norwegian firms have drawn upon their industrial asset base in $O \& G$ to branch into offshore wind activities. Given the lack of a clear domestic market, the incentive for firms to diversify has been primarily driven by the demand for 'offshore capabilities' in the rapidly emerging markets of Northern Europe (industry representative, authors' interview). In 2008-2009, however, the Norwegian O\&G industry was struck by the effects of the financial crisis, causing $O \& G$ prices to decline sharply and investments to decline. This came on top of a longer-term secular decline, as oil production peaked on the NCS in 2001. As a result, a further swathe of O\&G firms began to explore new opportunities in the offshore wind global production network. A supply chain report estimated that approximately 60 Norwegian firms have gained extensive experience in the offshore wind sector (Multiconsult 2012).

Most notably, the Norwegian energy majors Statoil and Statkraft collaborate on various offshore wind farm projects in the UK. Statoil has also decided to develop the world's largest floating offshore wind pilot project (Hywind Scotland) in Scotland (DN 2015). They have thus become lead firms in the offshore wind production networks. Informants in both Statkraft and Statoil claim that offshore wind is highly important to their long-term strategies, and that current marginal returns on investment are in part possible due to financial returns in other markets. Put differently, Statkraft and Statoil's current activities in O\&G, hydropower and other more mature sectors provide the financial strength for these firms to become lead firms in the offshore wind sector. In common with certain other prominent lead firms in the offshore wind deployment network such as DONG, Statkraft and Statoil are wholly and 
partially state-owned enterprises, providing a depth of historical assets and degree of financial support and political stability that has left them well placed to branch into the UK's privatised renewable energy sector.

The majority of Norwegian firms involved in offshore wind are supplier firms. These include a number of large firms, such as Nexans, Parker Scanrope and Draka (all umbilical and power cable suppliers), Aibel (transformer stations) and Fred Olsen Windpower (installation services). In general, most of the Norwegian supplier firms are in the offshore installation, foundation and sub-sea segments of the offshore wind production network, largely reflecting diversification from the offshore O\&G industry (Steen and Hansen 2014). Some companies such as the cable suppliers are able to reuse domestic production facilities in supplying foreign offshore wind markets. Other companies within shipping and engineering are more flexible in making use of infrastructure and facilities abroad, implying that value capture in their home regional economies in Norway is more limited.

A number of Norwegian firms have developed new concepts for offshore wind, particularly within the deployment segments of the wind industry value chain (Lema et al. 2011). For instance, OWEC Tower and Seatower have both developed new foundation solutions for fixed seabed conditions, whereas SWAY, WindSea and Statoil (Hywind) have developed floating foundation solutions. This pioneering installation of the world's first full scale floating wind turbine in 2009 (Steen and Hansen 2014) reflects the influence of Norway's very deep offshore waters in preventing the construction of conventional fixed-bottom structures. A number of Norwegian firms have also developed new vessel types for the offshore wind markets. 
Several Norwegian firms have been successful in accessing demonstration projects in foreign waters, based on alternative technological solutions to those dominant in in the main offshore wind markets in Northern Europe. These include demonstration projects in Germany (Alpha Ventus), the UK (Beatrice) and France (Fécamp). Statoil's Hywind pilot project in Scotland reflects its ability to benefit from more generous financial incentive schemes in other countries. In the same vein, Norwegian firms have also benefitted from R\&D programmes in overseas markets. For instance, UMOE Mandal's innovative project received funding not only from the Research Council of Norway and a regional R\&D fund, but also from the highly competitive UK Carbon Trust Wind Acceleratory Programme. At the same time, however, other Norwegian firms have struggled to verify their technologies in the absence of demonstration opportunities associated with a domestic market, constraining their capacity to move into international markets.

\subsection{Creating regional growth paths}

\subsubsection{Geography of OW development}

The majority of offshore wind activities in Norway are undertaken by large firms in the offshore $O \& G$ and maritime sectors, in which offshore wind generally constitutes only a marginal proportion of companies' total revenues. It is thus difficult to estimate the economic impacts for the Norwegian economy. The export value of goods and services for international offshore wind farms was approx. 2.3 billion Norwegian Krone in 2013, employing (domestically) approx. 800 person-years (Multiconsult 2015).

Norwegian firms involved in offshore wind are mainly located in regional O\&G clusters that are found in various parts of Norway, notably in coastal regions in the Western part of the 
country, in the capital region of Oslo and in Mid-Norway. The Western region, comprising the two major cities of Bergen and Stavanger, is the main offshore O\&G region in Norway. The capital region (Oslo) is home to many head offices, engineering and industrial design firms, but also a range of suppliers. And in smaller cities in the capital region there are a number of manufacturing plants notably for subsea equipment. In the Mid-Norway region we find Trondheim, not only the 'technology capital' city with a large R\&D sector, but also host to various manufacturing sites.

Two regions stand out in terms of explicitly attempting to develop localized networks of offshore wind related industry: the Mid-Norway region, and the Western region. Around 2009 , offshore wind cluster initiatives developed in these two regions, and, as mentioned previously, both received support through the Arena programme (see Table 6). 
Figure 10. Map of proposed areas for offshore wind farms in Norway (Source: NVE 2012)

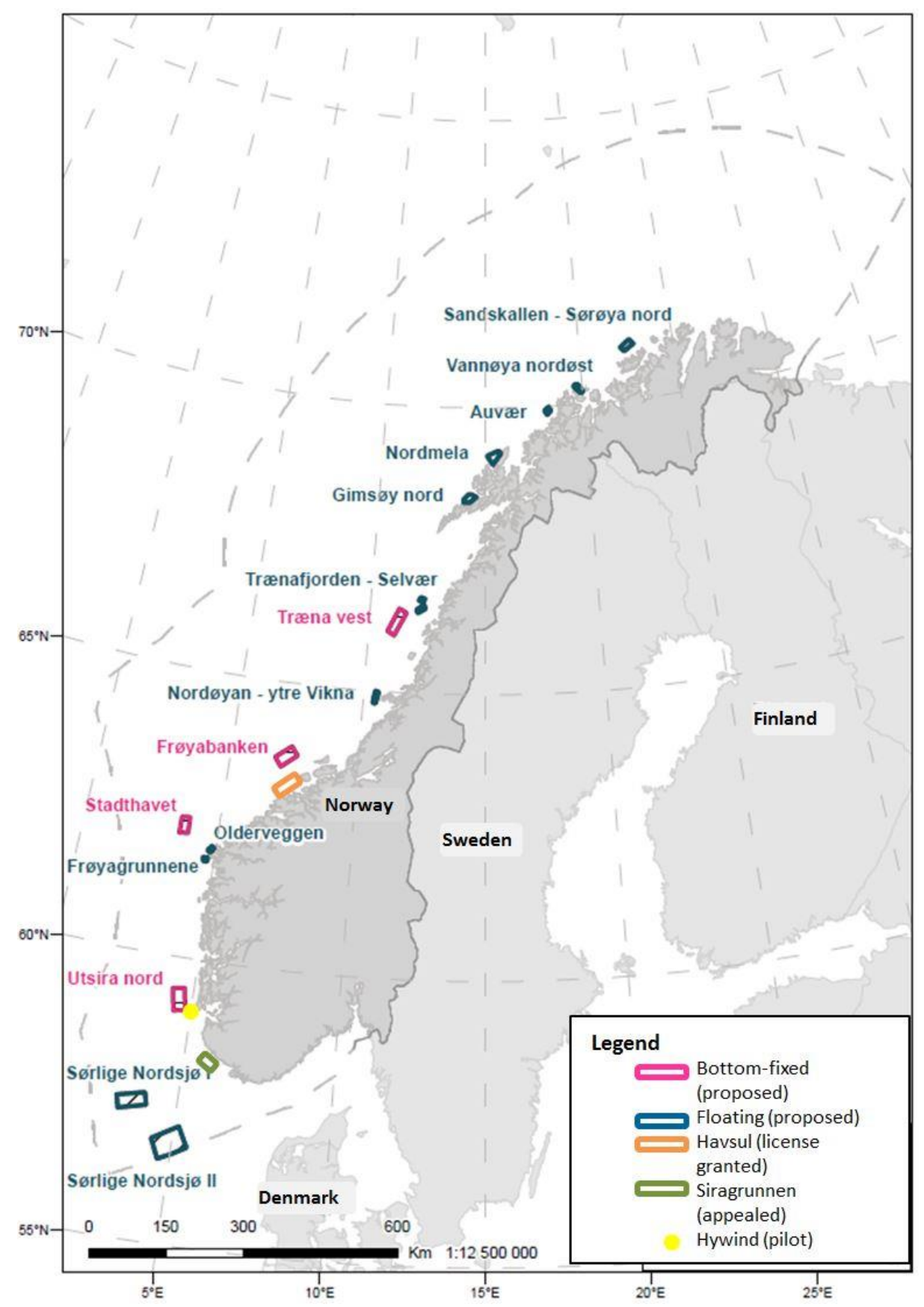

\subsubsection{Mid-Norway}

Towards the end of the 2000s an initiative to develop a 'Windcluster' was made in the region of Mid-Norway, with the core actors being located in the small industry town of Verdal, which is the third largest manufacturing site in Norway. Five actors were involved in the initial phase: the local cornerstone company Kværner Verdal (O\&G supplier), the local 
turbine manufacturer Scanwind, the O\&G supplier network Navitas (which had broadened its scope to include maritime renewables), the regional utility company NTE, and the NOWITECH R\&D centre in the Norwegian 'technology capital' city Trondheim (also located in Mid-Norway) (Steen and Karlsen 2014). The main idea was to couple capabilities from the onshore wind and broader energy sector with offshore $O \& G$ capabilities to move into the offshore wind market. This meant a deviation from the O\&G trajectory, which was perceived as declining. Political support and funding from local, regional and central levels was crucial to the establishment of the Windcluster organization which was facilitated by a local business development agency.

Within Norwegian contexts, Mid-Norway has become a relative pioneer in onshore wind, with the build-up of wind farms, test sites and wind energy related start-ups and R\&D since the early 1990s. The orientation towards offshore wind was primarily due to attempts at cornerstone company Kværner Verdal to find new markets as they faced a downturn in demand in the $O \& G$ industry. Kværner Verdal is specialized in manufacturing steel foundation ('jacket') structures for the $\mathrm{O} \& \mathrm{G}$ industry, and the branching process into offshore wind was made with relatively limited adaptation. Already in 2006 Kværner Verdal had succeeded in obtaining a contract on a German offshore wind farm, involving also several local sub-suppliers.

There are few examples of 'outside in' investments into the Norwegian offshore wind industry. A notable exception is the acquisition of the turbine manufacturer Scanwind in 2010 by US industry giant General Electric (GE) (see Steen and Karlsen 2014 for details). GE were seeking a turbine technology for the rapidly developing offshore market (which they had failed to develop in house), and were also attracted to Verdal by investment incentives 
provided during the O\&G downturn in 2009 and by R\&D capabilities in Mid-Norway. Both local authorities and central government actors made considerable efforts to attract GE to Verdal (Verdal municipality official, authors' interview). However, despite considerable resources being spent on the acquisition process, particularly by local stakeholders, GE left Verdal in 2011.

The withdrawal of GE from Verdal was followed by the 'drop-out' of both Kværner Verdal and the O\&G supplier network Navitas, which was the result of two main factors. First, a revitalization of the Norwegian $O \& G$ path took place as oil prices rose and new $O \& G$ discoveries were made on the NCS. Second, the anticipated domestic market did not materialize, and few cluster members managed to enter the international offshore wind market. As a compensation for lost regional engagement, a rescaling and reorientation strategy took place as the Windcluster took a national scope on the one hand (renamed to 'Windcluster Norway'), and started focusing on the onshore wind sector on the other. Nonetheless, the path creation attempt in offshore wind contributed to path renewal of the old O\&G path, as firms have developed new knowledge and connections.

\subsubsection{Western Norway}

In the Bergen region, the initiative for the Arena NOW (Norwegian Offshore Wind) project similarly came from firms. Here, the two main initial actors were a specialized start-up offshore wind installation firm (Norwind) and a firm developing offshore power transformer stations (Troll WindPower), the latter drawing on extensive experience from the offshore O\&G sector. Similar to the Mid-Norway case, Arena NOW was developed in collaboration with an offshore wind R\&D centre (NORCOWE). In contrast to Windcluster Mid-Norway, 
Arena NOW was particularly focused on the domestic offshore wind market from the onset, although international market opportunities were also being pursued by cluster members.

The cluster initiative was linked to the Havsul offshore wind farm project in particular, which at the time (2009) was expected to materialize. In 2013, however, the license owners of Havsul decided to abandon the project due to a lack of financial support in Norway. As a result, firms' engagement in the Arena NOW cluster initiative crumbled (Arena NOW project manager, authors' interview). And, similarly to the Windcluster Mid-Norway case, the revitalization of the $\mathrm{O} \& \mathrm{G}$ market had a detrimental effect on the interest in offshore wind among Arena NOW member firms. Moreover, links between Arena NOW and the R\&D centre NORCOWE appear to have been less developed than in the case of Windcluster MidNorway and the R\&D centre NOWITECH.

Despite the failed attempt at developing a formal offshore wind cluster, a number of firms in the region remain active in the sector, with many focusing on the international market. They argue that their geographic location vis-à-vis major offshore wind farm developments in the northern parts of both UK and German sectors of the North Sea imply a sailing distance that does not disadvantage them compared to major ports and industry sites in Denmark, Germany or the UK. Moreover, several firms argue that they have a particular advantage due to the presence of deep water ports, which are scarce in the more shallow coastal regions in the southern North Sea. Deep water ports allow for alternative installation and logistics solutions, such as the pre-assembly of foundation structures and turbine towers that could then be towed directly to site offshore and installed in a single operation. This is the approach being followed for the Hywind pilot project where the structures are being assembled in the Norwegian deep water port of Stord. 


\subsection{Summary}

Development of offshore wind capacity in Norway is highly unlikely in the foreseeable future due to the combined effects of a lack of financial support, abundant hydropower resources and the high costs associated with deep waters. In addition, the development of an offshore wind industry (i.e. firms and other actors involved in the production of equipment and services for the (global) offshore wind production network industry) has proven to be vulnerable to recurrent booms and busts in the $O \& G$ industry. The relationship between the mature O\&G sector and the embryonic offshore wind industry is thus contradictory: assets from $O \& G$ have nurtured the formation of the offshore wind path, while booming $O \& G$ markets have redirected attention, interest and resources away from offshore wind. Weaver and Steen (2013) suggest that despite challenges for offshore wind in Norway, there is significant long-term interest in offshore wind among firms in the $O \& G$ industry. Oil prices have plummeted since the summer of 2014, leading to layoffs of thousands of workers in the O\&G sector. This has reignited the 'life after oil' discourse and the issue of how to restructure the Norwegian economy away from its current state of oil dependency.

Despite the lack of a domestic market, various Norwegian firm and non-firm actors have prominent positions in the global offshore wind production network. Chief amongst the firms are Statoil and Statkraft, whose involvement as offshore wind farm developers and operators in the UK are core parts of their international growth strategies. Similarly to the large Norwegian equipment and service suppliers that are involved in offshore wind, Statoil and Statkraft emphasize their experience in handling large complex projects in offshore environments and their established supplier linkages as their critical inputs for innovation and cost-reduction in the offshore wind sector. An intriguing question from a Norwegian perspective is to the extent to which Statoil and Statkraft will draw on their established 
suppliers in Norway in their international offshore wind operations, as opposed to a focus on developing supplier linkages to the domestic markets in which they operate.

We conclude that Norway represents a constraining national institutional environment (Martin 2010; Steen and Hansen 2018) for new path creation in the offshore wind sector, although the industry is being enabled by the growth of offshore wind markets internationally, particularly in the proximate North Sea region. The principal path creation mechanisms have been branching from the offshore O\&G sector and R\&D-based innovation. Whilst the former has proven vulnerable, the latter has suffered from a lack of demonstration and piloting opportunities, implying that many new applications struggle to be verified and commercialised. There is, however, potential for relatively rapid change in context, and the historically developed capabilities of (especially) the O\&G sector provide relevant resources from which to develop a new path. As the experience of the UK and Germany underlines, however, if an offshore wind path creation process is to gain greater traction in Norway, political efforts to establish a financial subsidy scheme adapted to the needs of the industry will be required. 


\section{Discussion: Contrasting National Experiences of Path Creation in Offshore Wind}

\subsection{Introduction}

This section brings the three case together in a comparative framework, drawing out the main commonalities and differences between them. These are discussed in the context of the broader industrial trends set out in section 3 . The discussion is structured by the analytical framework developed in section 2 of the paper, focusing on regional assets, key actors, mechanisms of path creation and multi-scalar institutional environments and policy initiatives. In addition, we include a final sub-section which utilises this framework to outline the different path creation trajectories of offshore wind in each of the three national case studies.

\subsection{Regional Assets}

Our analysis of regional assets has allowed us to better capture a key component of the national and regional path creation process. Across our case studies, the varied combinations of assets - natural, industrial, infrastructural and material, human, institutional - have not only framed the nature of pre-formation and path creation processes, but also served to mould the character of path development.

All three of our cases studies underline the significant, though contingent and geographically differentiated, relationship between natural assets and path creation in offshore wind. On the one hand, it is clear from the examples of the UK and Germany, Europe's largest national 
markets, that natural assets provide important pre-conditions for the growth of offshore wind. In particular, the UK's extensive range of shallow waters and consistent wind speeds have proven to be a competitive advantage in its rapid ascent to become the world's largest offshore wind market. On the other hand, Norway has experienced some path creation in niche areas of the sector without, as yet, utilising its vast marine landscape and asset base for offshore wind development. The fundamental difference here is that the natural assets bases of Germany and the UK have been harnessed to stimulate a domestic market.

As such, our case studies illustrate how natural resource assets do not by themselves create growth paths, but require to be actively harnessed and valorised by particular actors and organisations. As Bridge (2008) has indicated in the similar case of extractive industries, the ownership of natural resources remains the reserved property of sovereign state institutions, granting them a key regulatory role in the development of industries based on the exploitation of such resources. This supports a strong national level influence on path creation in resource sectors. At the sub-national scale, the German and UK cases also indicate that investment and growth is concentrated in the port localities most geographically proximate to the offshore wind farms and natural asset base, particularly in deployment activities.

Our analysis of industrial and interrelated human (skills, knowledge etc.) assets provides considerable support to existing work in EEG that suggests new industries are drawn to locations with pre-existing industrial assets in related technologies, firm-competencies and knowledge fields (Boschma and Iammarino 2009; Neffke et al. 2011). Germany’s pioneering role in the onshore wind industry, coupled with its broader base of international expertise in energy related engineering, provided a distinctive pre-formation context for offshore wind industry, even in advance of domestic market formation. This is reflected in the ways in 
which some of the largest concentrations of firms and employment in Germany's offshore wind industry have been created away from the coast within Lander which possess strong and related engineering energy industry strengths (e.g. Nord-Rhine-Westphalia; BadenWurttemberg; Bavaria).

Similarly, despite the lack of a domestic Norwegian offshore wind market, high levels of industrial relatedness with $O \& G$ operations have provided a pre-formation context in which firms in the Mid-Norway and Western coastal regions have sought to transfer knowledge and capabilities into overseas offshore wind markets. In contrast, the geographies of the UK's industrial asset base has played a much lesser role than in Germany or Norway. Instead, path creation is taking place in 'greenfield' locations with proximity to wind farm sites, such as the Humber, rather than pre-existing heartlands of offshore $O \& G$ engineering such as North East England.

Whilst often overlooked in the EEG literature, our analysis demonstrates how infrastructural assets are shaping the geography of path creation in offshore wind (Maskell and Malmberg 1999). In both Germany and the UK, the limited locational freedoms of the offshore wind sector make it dependent upon the adjacent infrastructural assets of ports and marine complexes, particularly for the assembly and storage of materials and O\&M support. For example, the scale, scope and availability of ports and related infrastructural assets is a key locational factor behind local and regional path creation in the UK, reflecting its dependence upon the assembly of imported turbines and O\&M activities . By contrast, whilst many portrelated infrastructures have similarly been harnessed to create hubs for O\&M development on the German coast, the conversion of Bremerhaven's shipbuilding and port infrastructure into 
a centre for offshore wind engineering and manufacturing must also be understood in relation to a broader combination of industrial, human and institutional assets.

In summary, our case studies are characterised by differentiated asset bases, which combine to varying degrees to provide geographically distinctive path creation contexts. Germany appears to draw most extensively across all five domains of assets, including institutional (elaborated below), compared to Norway's focus on industrial and human assets and the UK's dependence on natural and infrastructural assets. This has direct implications for path creation and subsequent path development, orientating the UK path towards a market-led trajectory, whilst Germany, and to lesser extent Norway, are developing industrial growth paths.

\subsection{Key actors in path creation}

Two types of firms emerge as key players. First, the small, entrepreneurial firms, spin-offs and start-ups at the heart of EEG's conventional, endogenous notion of path creation (Boschma and Franken 2011; Morgan 2013). In Germany, for instance, the pioneering Northern German Offshore Consortium and subsequent spin-outs, mergers and start-up activities of turbine manufacturers, of such as Multibrid, REpower and BARD, exemplifies the primary role of indigenous firms in identifying market opportunities and introducing new products. As such, they played a catalytic role in what would become an industry-led growth path. Similarly, in both Mid-Norway and Western Norway regions, a combination of spinouts, diversifying firms and specialist start-up companies provided a key stimulus in exploring, if not fully creating, new regional growth paths. Moreover, Norwegian firms were 
pivotal in creating cluster-based networks to develop coordinated industrial activity in the emerging offshore wind market (e.g. Windcluster).

Our analysis also demonstrates the importance of TNCs and extra-regional firm networks in the path creation process. Across all three case studies, TNCs and connections to global production networks have shaped the path creation process. In the case of the UK's marketled path, offshore wind capacity has been dependent upon on incoming FDI from both large energy utilities such as Dong, RWE Power and Statoil and turbine manufacturers (e.g. Siemens). By contrast, Norway's industry-led growth path has been entirely reliant upon the internationalisation of firm activities for export markets, with Statoil and Statkraft, in particular, acting as lead firms in deployment networks, while a range of specialised Norwegian suppliers, mostly from the O\&G sector, have diversified into international markets. Occupying an intermediate position between the UK and Norway, Germany's path development has been characterised by the foreign acquisition of indigenous engineering firms, while Siemens itself acquired a leading Danish producer.

Our analytical framework has also sought to better capture the interrelations between firms and other actors and components of path creation. By moving beyond firm centric accounts of path creation, our attention to the multiple roles of state and quasi-state organisations makes an important contribution to better understanding and situating 'strategic agency' in the path creation process (Garud and Karnoe 2012). Situated within distinctive national VoC, states have shaped emerging offshore wind sectors through three principal domains of policy: horizontal (e.g. energy, R\&D), vertical (e.g. industrial policy) and spatial (e.g. planning; multi-level governance). 
With regard to horizontal policy, the process of market formation has created nationallyspecific support regimes for offshore wind. In both Germany and the UK, whilst the use of feed-in-tariffs and renewables obligations has stimulated the development of renewable energy more broadly, the premium rates offered to offshore wind have been critical in establishing the incentives to catalyse investment. Moreover, given the significant scales and long-lead times of offshore wind investment, our analysis also reveals how the relative stability and time-horizons of such market support regimes have shaped path creation (Cetkovic et al. 2016). The scale and enhanced incentives made available to the German offshore wind market since 2000, particularly through the later iterations of the Renewable Energy Sources Act (RESA), have generated the confidence necessary for the long-term investment strategies of offshore wind actors. At the same time, the UK's shift to a more constrained and market orientated subsidy system injected uncertainty into a domestic market which had grown into the worlds largest under the previous support regime. By contrast, the technology neutral nature of Norway's ECM has served to favour incumbent and more costefficient energy technologies such as hydro and onshore wind. Without the premium subsidies available in the UK and Germany, path creation processes in Norway have been shaped by the absence rather than presence of domestic demand.

Across all three cases, the primary form of industrial policy has been through state-funded R\&D programmes around offshore wind technologies. However, the timing, nature and scale of these initiatives vary significantly with important implications for path creation. Of particular importance have been the actions of the state, especially in Germany and to a lesser extent the UK and Norway, in supporting projects that provide a demonstration effect and stimulate domestic industrial capacity. As private sector actors struggled with capital costs of building Germany's first offshore wind farm, state actors intervened to catalyse and support 
its development. Despite similar pioneering turbine projects taking place in the UK as early as 2000 , comparable industrial policy initiatives have been largely absent until recent years. In the case of Norway, state programmes and agencies, such as ENOVA, were also instrumental in supporting early demonstration projects around floating platform technologies. Without the parallel development of a domestic market, however, these have had limited effects on industrial growth.

The final dimension of the state's role as an actor is concerned with spatial policy. Across all three case studies, the planning systems for offshore wind has become more centralised and formalised over time, reflecting the need to bring greater stability and coherence to what was an initially fragmented and often conflictual marine environment (Gazzola, Roe and Cowie 2015). A key difference is between the zonal approach to offshore wind planning in Germany and Norway, whereby all development must be located within pre-designated spatial zones, and the UK's criteria-based system of assessing individual projects against various environmental, safety and other standards (Toke 2011).

Taken together, our analysis reveals how path creation processes in each country have been influenced by varying degrees of policy alignment, often changing over time, across geographical scales and domains of activity. On the one hand, Germany's industry-led path has been enabled by a stable and long term policy context that has coordinated both market and industrial development and allowed proactive policy support for path creation at subnational scales (Cetkovic et al. 2016). On the other hand, the UK's market-led path was initially catalysed by a supportive energy market but weakly aligned to the promotion of industrial development. More recently, this misalignment has been partly reversed with the belated introduction of industrial policy within a more constrained and uncertain market 
context, at least prior to the dramatic cost reductions that have occurred since 2016. Norway stands apart from both the UK and Germany because of the relative absence of measures to stimulate a domestic offshore wind market, but nonetheless highlights the role that industrial policy can play in supporting export orientated growth.

\subsection{Mechanisms of Path Creation}

Our analysis has sought to provide new empirical insights into the candidate mechanisms of path creation, focusing on three: diversification and branching; transplantation; and indigenous creation (Dawley 2014; Martin and Sunley 2006). Diversification emerges as a prominent mechanism within the pre-formation contexts of strong and related industrial asset bases, principally onshore wind in Germany and O\&G in Norway. For example, Germany stands alone in turbine manufacture in our cases, derived in part from processes of diversification and spin-off that link back to firms operating in the pioneering onshore wind sector in the 1970s and 1980s. Moreover, Hamburg's role as the home of energy utilities and the certification of energy technologies provided an industrial and human asset base for diversification and branching, making it the "brain port of offshore wind in Northern Germany" (Fornhal et al. 2012 p. 849). At the same time, Statoil and Statkraft have harnessed Norway's distinctive industrial assets in the O\&G sector to diversify large scale marine and energy related project development competences into the offshore wind market. Elsewhere in the value chain, firms with O\&G origins such as Nexans, Aibel and Fred Olsen Windpower have diversified their expertise in cables, substations and deployment activities to match the needs of offshore wind. 
For the UK, diversification and branching has been more limited. At one level, this reflects the apparent absence of relatedness between existing industrial assets and the emerging offshore wind industry, certainly to the extent witnessed in Germany and Norway. At another level, it reflects the difficulties facing domestic firms in the UK's relative late-comer industrial growth path, as international technological and market leadership has already been established by incumbents elsewhere (e.g. turbines from Germany; deployment activities from Norway). Interestingly, key areas which UK firms have diversified into, such as substations and transmission technologies, are fields which are relatively shielded from international competition due to UK-specific technical standards on electricity transmission.

The case studies also highlight the importance of the diversification of infrastructure. In this sense, we extend existing approaches in the EEG literature that are predominately concerned with sectors, firms and knowledge assets (Boschma and Frenken 2009; Neffke et al., 2011). Indeed, the diversification and conversion of port facilities and shipyards have generated competitive advantages for regions in attracting key manufacturing investments in localities such as the Humber and Bremerhaven. Similarly, the emergence of O\&M and deployment ports has involved their smaller-scale conversion from previous uses such as cargo handling or fishing. Some cases of infrastructural diversification, such as branching from Norwegian $O \& G$ facilities or the conversion of premises for technical and management services in Hamburg, are firm-led, reflecting a pre-formation context rich in industrial and human assets, whereas others have been driven by a range of non-firm actors, for example the regional state in the case of Bremerhaven.

This paper offers further support for recent work in EEG which emphasise the roles of exogenous linkages and networks in path creation (Binz et al. 2016: Zhu et al. 2017). Our 
approach draws on GPN perspectives to provide a broader notion of transplantation which better captures the potential two-way orientations of inward-investment (outside-in) and outward-investment (inside-out) in stimulating path creation (Coe and Yeung 2014). Of particular importance in understanding these varying roles for transplantation mechanisms are the evolution of 'strategic couplings' between regional assets and lead firms within broader production networks. Here, our case studies offer three sets of contrasting orientations and coupling types.

The UK is heavily dependent on 'outside-in' forms of investment. At one level, this is characterised by the conventional notion of transplantation around key inward investment projects (e.g. Siemens in Hull) as the stimulus for local and regional paths of growth. At another level, it reflects the broader integration and dependence of the UK's offshore wind sector within externally controlled production networks, covering both the manufacturing and deployment chains. Central to this dynamic has been a pre-formation and path creation context shaped by the strength of natural assets, and the associated state-enabled market, relative to a weak industrial asset base. In GPN terms, path creation occurs largely through a form of structural coupling characterised by a dependence upon by external actors connecting the path into global production networks (Coe and Yeung 2015.

Conversely, Norway represents a set of path creation processes which are almost entirely dependent upon 'inside-out' forms of investment, involving the expansion of domestic firms into international markets. In contrast to the UK, Norway's exogenous linkages have emerged through the strength of its industrial assets relative to the lack of a domestic market. As a result, Norway's path creation is evolving through the formation of an indigenous coupling, with domestic firms reaching out to international markets to form, or integrate within, global 
production networks whilst retaining considerable autonomy and potential value capture for their origin region and path.

Germany represents a more balanced case, characterised by the co-evolution of both insideout and outside-in processes. Unlike the UK's reliance on transplantation style investments, Germany's outside-in dynamics have evolved around acquisitions of domestic firms. Importantly, both Suzlon and Arriva's outside-in investments have led to the continued development and internationalisation of their German based operations. Conversely, Siemens' acquisition of Bonus in Denmark reflects strategy of fast-track entry to the offshore wind market through the capture of extra-regional assets. Germany can be characterised by multiple modes of couplings which have evolved through connections to a diverse and rich regional asset base. On the one hand, path creation is evolving through a form of indigenous coupling, driven by the likes of Siemens reaching out externally whilst retaining leadership and value capture within the origin base. On the other hand, a set of functional couplings have also emerged, moulded around the valorisation of industrial and human assets within a growing state-conditioned market.

In practice, indigenous creation is centred upon $R \& D$ and prototyping activities most commonly undertaken within state funded research programmes. In both Germany and the UK, such initiatives have sought to catalyse and support on-going path creation processes, rather than being the original source. They emerged earlier in Germany than in the UK and were able to make a stronger contribution to path creation process, for example the AlphaVentus and FINO programmes. In Norway, elements of indigenous creation have emerged around the floating platform turbine technologies, most notably the Hywind project led by Statoil and with limited state funding through the Enova R\&D programme. As the case 
studies demonstrate, ostensibly indigenous forms of path creation may be supported by exogenous resources in practice, particularly for emerging technologies like offshore wind which require state support (Essletzbichler 2012).

In summary, whilst we have sought to identify the particular roles of our three candidate mechanisms in each case, it is clear that these can only be understand as part of a more dynamic, indeed interdependent, set of interrelations between regional assets, actors and mechanisms. We reveal how the operation and indeed combination, of mechanisms not only vary between cases, but also assume different roles at different stages of the path creation and development process. In Germany and Norway, diversification and branching appears to have played a more prominent role in the earlier stages of path creation, followed by growing integration with extra-regional networks which added additional impetus and scope to the emerging path. This can be contrasted with accounts of path creation as a regional 'anchoring' process that is most dependent upon the importation of external resources in its early stages (Binz et al. 2016), reflecting its contingent and context-specific nature. In the UK, by contrast, transplantation remains the main mechanism for path creation with little real indication of the increased anchoring or embedding of extra-regional resources (ibid).

\subsection{Multi-scalar Institutional Environments and Policy Initiatives}

Our fourth analytical strand has sought to place the various combinations of assets, actors and mechanisms within the various multi-scalar institutional environments that mediate path creation. As noted earlier, recent work within EEG has sought to conceptualise these geographically specific contexts as representing either enabling or constraining institutional environments for path creation (Martin 2010). However, for operational clarity our analysis 
reveals the need to move beyond this binary distinction as institutional environments can be comprised of both enabling and constraining elements at a particular point in time (Steen and Hansen 2018).

As a 'simple' LME, the enabling element of the UK institutional environment is based upon the central government regulation of the electricity market, providing financial incentives for suppliers to source an increasing proportion of electricity from renewables, although this became more constrained after 2012 on the basis of concerns about the affordability of subsidies and the transition towards a competition-based support regime (Cetkovic et al. 2016). By contrast, the reliance on market regulation, the lack of strategic state-scienceindustry coordination and the dominance of short-termist investment regimes is associated with limited domestic industrial development, making the UK dependent on attracting inward investment across the whole manufacturing and deployment chain. In response, the publication of an Offshore Wind Industrial Strategy in 2013 represents the state's attempt to accelerate the development of a more balanced and coordinated national offshore wind regime.

Germany has provided a more integrated enabling environment for both market and industryled development as a 'compound' CME. In terms of market-led growth, offshore wind development paths have emerged as part of a long and pioneering history of state support for renewable energy, most recently manifest in the Energiewende. Moreover, a high degree of strategic state-science-industry coordination has ensured that energy policy has been better connected to industrial policy at both federal and lander levels than in the UK. Accordingly, the German offshore wind industry is characterised by a more integrated and deeper domestic industrial structure, reflecting the more diverse technological roots of the sector. As a result, 
the corporate structure spans a number of large focal firms in offshore wind global production networks (e.g. Siemens; RWE) and the continued presence of small and medium-sized suppliers.

By contrast, Norway's path creation processes have been framed by a largely constrained institutional environment that has prevented the establishment of a domestic market. High levels of strategic coordination between government, science and industry have perpetuated the established energy system, shaped by powerful incumbent actors like Statoil and Statkraft. Despite various government statements of ambition to develop wind and marine energy, these have remained low priority given Norway's historical self-sufficiency in hydropower. At the same time, the national industrial dominance of the $O \& G$ sector has proven influential in shaping the wider industrial and policy landscape. Whilst providing a potential industrial asset base for diversification, the sustained growth of $O \& G$ has served to redirect attention and investment away from offshore wind. In the absence of a financial subsidy regime to support the niche development of an offshore wind market, path creation in Norway has been largely industry-led, particularly through the activities of the energy majors Statoil and Statkraft in the ownership and development of projects in overseas markets (Steen and Hansen 2018). This has been supplemented by an ever increasing range of export orientated offshore wind installation and supplier firms. Indeed, the breadth and depth of the emerging growth path may increase further in the wake of more recent slumps in the O\&G markets, reigniting industrial attention to diversification as part of a 'life after oil discourse' (Steen 2016).

Sub-national institutional environments also play an important role in enabling and constraining path creation processes at the regional scale. This is strongly conditioned by the 
particular varieties of decentralisation found in the three case study countries. Thus, the autonomy and resources of the German lander within a 'compound' CME (Cetkovic et al. 2016) have created a largely enabling context for offshore wind development, as demonstrated by the case of Bremerhaven, although this has also depended on alignment with national-level support mechanisms (Simmie et al. 2014). The asymmetrical nature of UK devolution, by contrast, means that different regions hold different powers, granting Scotland a clear institutional and political advantage over English localities, for instance. Yet this is balanced by the geographical advantage of proximity to wind farm sites for selected localities along the East coast of England, particularly Humberside. As a 'simple' CME (Cetkovic et al. 2016), Norway combines strong central direction with well-resourced local and regional agencies, although the impact of various cluster and $\mathrm{R}$ and $\mathrm{D}$ initiatives has been limited by the lack of domestic market formation.

\subsection{Path Creation Trajectories}

Here, we outline how the four main elements of path creation incorporated in our framework interact to shape the emergent trajectories of path creation and development in each case. This allows us to explore and characterise the often neglected qualitative dimensions of path creation processes. We refer to not only the functional role of the country within the offshore wind industry and the modes of investment and coupling associated with this, but also the characteristics of the path itself in terms of its depth and indigenous or exogenous orientation (Table 8). 
Table 8: Contrasting paths: dynamics and development trajectories

\begin{tabular}{|l|l|l|l|l|}
\hline & $\begin{array}{l}\text { Functional } \\
\text { role }\end{array}$ & $\begin{array}{l}\text { Mode of } \\
\text { investment }\end{array}$ & $\begin{array}{l}\text { Mode of } \\
\text { Coupling }\end{array}$ & $\begin{array}{l}\text { Characteristics of } \\
\text { path }\end{array}$ \\
\hline Germany & $\begin{array}{l}\text { Manufacture/ } \\
\text { deployment }\end{array}$ & $\begin{array}{l}\text { Inside- } \\
\text { out/outside-in }\end{array}$ & $\begin{array}{l}\text { Indigenous- } \\
\text { Functional }\end{array}$ & $\begin{array}{l}\text { Deep-rooted, } \\
\text { indigenous }\end{array}$ \\
\hline UK & Deployment & Outside-in & Structural & $\begin{array}{l}\text { Shallow, exogenous } \\
\text { (inward) }\end{array}$ \\
\hline Norway & $\begin{array}{l}\text { Overseas } \\
\text { deployment } \\
\text { and supply }\end{array}$ & Inside-Out & Indigenous & $\begin{array}{l}\text { Intermediate } \\
\text { depth, exogenous } \\
\text { (outward) }\end{array}$ \\
\hline
\end{tabular}

Of our three cases, Germany has developed the most deep-rooted and holistic path to date, characterised by internationally leading roles within both the deployment and manufacturing segments of the production network. Harnessing the broadest array of regional assets within the pre-formation context, Germany's coordinated policy regime has enabled all three mechanisms of path creation to overlap and create a path characterised as involving both indigenous and functional modes of coupling.

In comparison, path creation in the UK and Norway has evolved in more partial and selective ways, affecting the depth, breadth and sustainability of associated forms of economic development. The UK's growth path is developing in a relatively shallow manner, focusing on deployment rather than manufacturing functions and framed within a structural form of coupling dependent on exogenous 'outside-in' investment. Whilst a reactive and belated industrial policy has sought to try and establish a more embedded form of industrial growth, the path's character reflects its creation around a narrow set of lower-order assets and a market-led enabling environment. 
By contrast, Norway's path is emerging in an entirely exogenous, 'inside-out' fashion around a relatively confined set of actors and deployment and supply functions. Although indelibly constrained by an institutional environment that has prevented a domestic market demonstration effect as witnessed in the UK and Germany, Norway's path has nevertheless been created through the diversification of industrial and knowledge-rich assets, giving it an intermediate level of depth through the mobilisation of these underlying assets. In this sense, the breadth of the path is more confined than in the UK, based upon specific roots in the O\&G sector, but has developed as part of an indigenous coupling process. As a result, it offers the potential for Norway to benefit as the home of, rather than the host market for, large lead firms, strategic partners and specialised firms within emerging global production networks. 


\section{Conclusions}

The aim of this paper has been to contribute to path creation research in EEG and beyond by developing a fuller understanding of the actors, processes and contexts behind the creation of new industrial paths. This was informed by the development of a multi-actor and multi-scalar conceptual framework which stresses the interaction between regional assets, key actors, mechanisms of path creation and multi-scalar institutional environments. Our framework brings together insights from EEG research on path creation and work on global production networks which have remained largely separate fields of research (though see Mackinnon 2012). It is designed to foster a broader relational understanding of path creation and development, in contrast to the focus on regional-level processes in EEG (Boschma 2016), emphasising the role of national states and TNCs alongside indigenous firms and entrepreneurs. The paper also provides a novel and timely contribution to recent debates exploring 'how' to do evolutionary research within the rapidly developing field of EEG (Pike et al 2016). Our longitudinal mixed methods approach, combining 'incorporated comparison' and 'deep contextualisation', underlines the value of international comparative analysis in specifying how institutional variations mediate industry dynamics and path creation outcomes (Boschma 2016; Trippl et al. 2017).

A central contribution of the paper has been to challenge the assumption in the GPN literature that strategic coupling is primarily a regional-level process (Coe et al. 2004). Instead, our account of the offshore wind sector indicates that it occurs primarily at the national scale through the coupling of assets to particular mechanisms of path creation, with important regional implications. In particular, our analysis points to the formative roles of national VoC in shaping industry dynamics and regional outcomes. For instance, Germany's 'compound' CME' (Cetkovic et al 2016) accommodates high levels of strategic coordination between 
government and industry and regional decentralisation, fostering an integrated and deeprooted offshore wind industry, within an elaborate division of labour between regions. By contrast, reflecting its classification as a 'simple' LME, the approach of the UK state has privileged market regulation over industry development, tempered by an important element of asymmetrical devolution as reflected in the Scottish Government's strong support for the offshore wind industry. The paper has also addressed Trippl et al's (2017 p. 15) challenge to explore "how and why regions differ in their capacities to exploit nation-state led growth impulses", understanding regional path creation as crucially dependent on processes of institutional and political alignment between the regional, national and supra-national scales.

The paper's account of path creation across three national cases allows us to draw out some broad policy implications. First, the cases demonstrate the importance of market support for emerging sectors that are not yet price competitive with established technologies, requiring states to construct domestic markets through technology-specific pricing regimes. In the case of offshore wind, the dramatic costs reductions experienced over the past couple of years may render this process less onerous for 'latecomer' states, although such cost reductions could be confined to countries with an established industry. At a time of reived interest in industrial policy internationally (Bailey et al. 2015), the German experience in particular emphasises the importance of 'vertical' supports for emerging industries through R and D schemes, the encouragement of science-industry collaboration and financial assistance for the installation of equipment. With reference to spatial policy, the German case also demonstrates how regional decentralisation and institutional diversity fosters experimentation and innovation as a plurality of actors become committed to emerging technologies like offshore wind. In addition, our analysis highlights the importance of creating stable and coordinated planning regimes to manage emerging industries, particularly ones based upon large-scale 
infrastructural projects. While liberal LMEs may be better at generating radical policy innovations, such as the introduction of a market-based support regime in the UK, the more overarching policy lesson concerns the need for policy consistency and stability over time to provide confidence and certainty for investors. This is most apparent in the German case, reflecting the consensual nature of decision-making processes in CMEs (Cetkovic et al. 2016).

Finally, the analysis also raises some theoretical implications for the further development of the analytical framework presented in the paper, whereby key actors, operating within institutional environments, valorise regional assets and match or strategically couple them to mechanisms of path creation. First, future iterations of the framework should go beyond the incorporation of a diverse range of actors to develop a stronger sense of strategic agency, particularly in terms of the broader social, political and discursive processes through which emerging industrial paths are promoted and contested by path advocates and incumbent interests respectively (Steen 2016). Here, recent work within sustainability transition studies on the 'empowerment' of technological niches is of great potential interest (Smith and Raven 2012). Second, while mechanisms of path creation have been treated as discrete and separate in the EEG literature (see Martin and Sunley 2006), our account has highlighted that they are often overlapping and inter-twined in practice, requiring a more concrete and grounded understanding of their role in generating and reproducing industrial growth paths. One element of this concerns the relationship between actors and mechanisms, particularly in terms of developing a clearer understanding of the role of different actors in doing the work of coupling regional assets to often overlapping mechanisms of path creation. Third, the future elaboration of the framework should move beyond the three broad modes of strategic coupling used in this paper, which remain macro-level and national in nature (Coe and Yeung 
2015), to develop a fine-grained, micro-level understanding of the types of regionallyspecific couplings occurring between firm and regional assets. 


\section{Acknowledgements}

This paper has been informed by research supported by Research Council of Norway, including Grant 209697 (CenSES — Centre for Sustainable Energy Studies and Grant 255400 InNOWiC - Internationalisation of Norwegian Offshore Wind Capabilities.

We would like to acknowledge the very helpful input of Andy Pike, Robert Hassink and the late Susan Christopherson at various points in the development of this programme of research.

We are also grateful to Nick Gallent and three anonymous reviewers for their constructive comments on an earlier version of this paper and to all our respondents for sharing their time and knowledge.

The usual disclaimers apply. 


\section{References}

4cOffshore. 2016. Market Overview Report: August. 4cOffshore: Lowestoft.

4cOffshore. 2017. Market Overview Report: February. 4cOffshore: Lowestoft.

Arbeitnehmerkammer_Bremen (2014) Die (Offshore-)Windenergieindustrie in

Bremen/Bremerhaven, Arbeitnehmerkammer_Bremen :Bremen

Bailey, D., Cowling, K. and P.R Tomlinson. (eds) 2015 New Perspectives on Industrial Policy for Modern Britain. Oxford University Press

Bergek, A. and S. Jacobsson. 2011. Fremmer grønne sertifikater ny teknologi? In Energirikdommens paradokser: Innovasjon som klimapolitikk og næringsutvikling, ed. S.K. J. Hanson, O. Wicken. Oslo: Universitetsforlaget.

Binz, C., Truffer, B. and Coenen, L. 2016. Path creation as a process of resource alignment: industry formation for on-site water recycling in Beijing. Economic Geography 92:172-200.

BIS. 2015. Offshore_wind_report_Bremerhaven_2012. BIS Bremerhavener Gesellschaft für Investitionsförderung und Stadtentwicklung mbH (Bremerhaven Economic Development Company): Bremerhaven.

Boas T.C. 2007. 'Conceptualizing Continuity and Change: The Composite-Standard Model of Path Dependence', Journal of Theoretical Politics 19.1. pp. 33-54 
Boasson, E.L. 2011. Fridtjof Nansen Institute, Bergen.

Boschma, R. 2016. Relatedness as a driver of regional diversification. Regional Studies. DOI: 10.1080/003443404.2016.1254767.

Boschma, R. and K. Frenken .2006. Why is Economic Geography not an Evolutionary Science? Towards an Evolutionary Economic Geography, Journal of Economic Geography, 6 3, 273-302.

Boschma, R. and Frenken, K. 2011. Technological relatedness and industry branching in H. Bathelt, M.P Feldman and D.F Kogler (eds) Dynamic Geographies of Knowledge Creation and Innovation. London and New York, Routledge, pp. 64-81.

Boschma, R and Iammarino, S. 2009. Related variety, trade linkages and regional growth in Italy. Economic Geography 85: 289-311

Boschma, R. and R. Martin (2007), 'Constructing an Evolutionary Economic Geography', Journal of Economic Geography, 7 (5), 537-548.

Bmwi (2015) Offshore-Windenergie. Ein Überblick über die Aktivitäten in Deutschland, p. 41p. Bundesministerium für Wirtschaft und Technologoe, Blomberg.

Bridge, G. 1998. Global production networks and the extractive sector: governing resourcebased development, Journal of Economic Geography, 8, pp. 389-419 
Bridge G., Bouzarovski, S., Bradshaw, M. \& Eyre, N. 2013. Geographies of energy transition: Space, place and the low-carbon economy. Energy Policy. 2013, 53-331

Brooks, M., Cullinane, K and Pallis, T (2017) "Revisiting port governance and port reform: A multi-country examination.” Research in Transportation Business \& Management. 22 (1). pp1-10.

Bruns, E, and Ohlhorst. D. 2011. Wind Power Generation in Germany: Transdisciplinary View on the Innovation Biography. Journal of Transdisciplinary Environmental Studies, 10, 1, pp 45-67

Buen, J. 2006. Danish and Norwegian wind industry: The relationship between policy instruments, innovation and diffusion. Energy Policy 34: 3887-3897.

Bundesregierung (2002) Strategie der Bundesregierung zur Windnutzung auf See, p. 26, Berlin.

Bundesnetzagentur. 2016. Offshore Network Development Plan 2025 confirmed. Press Release, $28^{\text {th }}$ November, Bundersnetzagentur: Bonn.

BVG Associates (2013) Building an Industry: Updated Scenarios for Industrial Development. Report for RenewableUK and The Crown Estate. BVG Associates: Swindon.

BVG Associates (2014) UK offshore wind supply chain: capabilities and opportunities. BVG 
Associates: Swindon.

BVG Associates (2017) Renewable energy policy workshops. Presentation given to Greenport Hull Workshop 23-24 February. The Logistics Institute, Hull University Business School. BVG Associates: Swindon.

Campos Silva, P., Klagge, B. 2013. The evolution of the wind industry and the rise of Chinese firms: From industrial policies to global innovation networks, European Planning Studies, 21.9. 1341-1356

Carbon Trust. 2014. Detailed appraisal of the offshore wind industry in China. Carbon Trust: London

Cetkovic, S., Buzogany, A. and Schreurs, M. 2016. Varieties of energy transition in Europe: Political-economic foundations of onshore and offshore wind development. WIDER Working Paper 2016/18. United National University World Institute for Development Economics Research. wider.unu.edu.

Chapman, K. and Walker, D. (1991). Industrial location. Principles and policies, Blackwell, Oxford.

Chang H-J., Andreoni A. and Ming L K. 2013. International Industrial Policy Experiences and the Lessons for the UK, Future of Manufacturing Project: Evidence Paper 4. London: Foresight, Government Office for Science 
Clark, P. 2015. Germany threatens UK dominance in wind power, Financial Times, March $10^{\text {th }}$

Clark, P. Bounds, A. and Pickard, J. 2014. Elation and puzzlement over Yorkshire wind plant, Financial Times, $25^{\text {th }}$ March.

Coe, N., Hess, M., Yeung, H., Dicken, P., Henderson, J. 2004. Globalizing regional development: a global production networks perspective. Transactions of the Institute of British Geographers, 29(4): 468-485.

Coe, N.M., Dicken, P. and Hess, M. 2008. Global production networks: realizing the potential, Journal of Economic Geography, 8, 3, pp. 271-295

Coe, N. and Yeung, H.W-C. 2015. Global Production Networks: Theorising Economic Development in an Interconnected World. Oxford: Oxford University Press.

Cooke, P. 2012. Transversality and transition: green innovation and new regional path creation. European Planning Studies 20:817-834.

Cowell, R. Ellis, G. Sherry-Brennan, F. Strachan, P.A,. Toke, D. 2015. Rescaling the governance of renewable energy: Lessons from the UK devolution experience, Journal of Environmental Policy \& Planning, http://dx.doi.org/10.1080/1523908X.2015.1008437

Crown Estate. 2013. A Guide to UK Offshore Wind Operations and Maintenance, A report by Crown Estate, Scottish Enterprise and GL Garrad Hassan, Crown Estate: London. 
Dahl, M. S., Østergaard, C. R., \& Dalum, B. (2010). Emergence of regional clusters: The role of spinoffs in the early growth process. In R. Boschma, \& R. Martin (Eds.), The handbook of evolutionary economic geography (pp. 205). Cheltenham, UK: Edward Elgar Publishing,

Dawley S. 2014. Creating New Paths? Offshore Wind, Policy Activism, and Peripheral Region Development. Economic Geography, 90: 91-112.

Dawley S, MacKinnon D, Cumbers A, Pike A. 2015: Policy activism and regional path creation: the promotion of offshore wind in North East England and Scotland. Cambridge Journal of Regions, Economy and Society 8(2):257-272.

Department for Business, Energy and Industrial Strategy (BEIS) (2017a) Contracts for difference second allocation round results.

https://www.gov.uk/government/publications/contracts-for-difference-cfd-second-allocationround-results. Last accessed 19 January 2018.

Department for Business, Energy and Industrial Strategy (BEIS) (2017b) Energy Trends September 2017. https://www.gov.uk/government/collections/energy-trends

Department for Business, Energy and Industrial Strategy (BEIS) (2017c) Energy Trends December 2017. https://www.gov.uk/government/collections/energy-trends

Department for Energy and Climate Change (DECC). 2013. Electricity Market Reform Delivery Plan. DECC: London. 
DECC. 2015. Contracts for Difference (CFD) Allocation Round One Outcome. DECC: London.

De Vries E. 2009. Boomtown Bremerhaven: The Offshore Wind Industry Success Story, Renewable Energy World 12, 1-15

Dicken, P. 2015. Global Shift. Mapping the Changing Contours of the World Economy. $7^{\text {th }}$ Edition. Sage: London

DN. 2015. Statoil bygger Hywind pilotpark. In Dagens Næringsliv.

Elola, A.; Parrilli, M.D; Rabellotti, R. 2013 'The Resilience of Clusters in the Context of Increasing Globalization: The Basque Wind Energy Value Chain', European Planning Studies, 21, 7, 989-1006

Energi21. 2008. Energi21 - A collective R\&D strategy for the energy sector. Oslo.

Energi21. 2014. Strategi 2014. Oslo: Energi21.

Energirådet. 2008. Vindkraft offshore - industrielle muligheter for Norge. 
Engen, O.A. 2009. The Development of the Norwegian Petroleum Innovation System: A Historical Overview. In Innovation, Path Dependency and Policy: The Norwegian case, ed. B. Verspagen; J. Fagerberg; and D. Mowery, 179-207. Oxford: Oxford University Press.

Ernst and Young. 2015. Offshore wind in Europe: Walking the tightrope to success. Ernst and Young: Paris.

Essletzbichler, J. 2012. Renewable energy technology and path creation: a multi-scalar approach to energy transition in the UK. European Planning Studies 20:791-816.

EWEA. 2011. Wind in Our Sails. The Coming of Europe's Offshore Wind Energy Industry. European Wind Energy Association: Brussels.

EWEA. 2015. Wind energy scenarios for 2030. European Wind Energy Association, EWEA: Brussels

EWEA. 2016. The European offshore wind industry -key trends and statistics 2015. European Wind Energy Association, EWEA: Brussels

Fisher. B. 2015. Creating new pathways in peripheral regional economies: the offshore wind and printable electronics industries in the North East of England. Unpublished PhD. Newcastle University 
Fornahl D., Hassink R., Klaerding C., Mossig I. and Schroder H. 2012. From the Old Path of Shipbuilding onto the New Path of Offshore Wind Energy? The Case of Northern Germany, European Planning Studies 20, 835-55.

Garud, R. and P. Karnee 2001. Path creation as a process of mindful deviation in R. Garud and P. Karnoe (Eds.) Path Dependence and Creation. Mahwah, NJ, Lawrence Earlbaum Associates, pp. 1-38.

Garud R. and Karnøe P. 2003. Bricolage versus breakthrough: distributed and embedded agency in technology entrepreneurship, Research Policy 32, 277-300.

Gazzola P, Roe M, Cowie P. 2015. Marine spatial planning and terrestrial spatial planning: reflecting on new agendas. Environment \& Planning C: Government \& Policy, 33, 5, 11561172.

Gereffi, G., Humphrey, J. and Sturgeon, T. 2005. The Governance of Global Value Chains. Review of International Political Economy: 78-104.

Goddard, J.; Robertson, D.; and Vallance, P. 2012. Universities, technology and innovation centres and regional development: The case of the North-East of England, Cambridge Journal of Economics 36:609-27

Grabher, G. 1993. The Weakness of Strong Ties: The Lock-in of Regional Development in the Ruhr Area, in G. Grabher (ed), The Embedded Firm: On the Socioeconomics of Industrial Networks, London: Routledge, pp. 255-277. 
GWEC. 2014. Global Wind Report 2013. Global Wind Energy Council (GWEC), GWEC:

Brussels

GWEC. 2015. Global Wind Report 2014. Global Wind Energy Council (GWEC), GWEC:

Brussels

GWEC. 2016. Global Wind Report 2015. Global Wind Energy Council (GWEC), GWEC:

Brussels

GWEC. 2017. Global Wind Report 2016. Global Wind Energy Council (GWEC), GWEC:

Brussels

Hall, P. and Soskice, D. (eds) 2001. Varieties of Capitalism: The Institutional Foundations of Comparative Advantage. Oxford: Oxford University Press.

Haggett, C. 2008. Over the Sea and Far Away? A Consideration of the Planning, Politics and Public Perception of Offshore Wind Farms. Journal of Environmental Policy \& Planning. 10 .3. 289-306.

Hannah, L. (1979) Electricity before Nationalisation: A Study of the Development of the Electricity Supply Industry in Britain to 1948. Macmillan Press; London.

Hannah, L. (1982)_Engineers, Managers and Politicians: Electricity Supply Industry in Britain from 1948 to the Present. Macmillan Press; London. 
Hansen, G.H. and M. Steen. 2011. Vindkraft til havs. Teknologi- og industriutvikling fra et norsk bedriftsperspektiv: CenSES.u.

Hauser, H. 2009. The current and future role of technology and innovation centres in the UK, London: Department for Business Innovation and Skills.

HM Government. 2013. Offshore Wind Industrial Strategy: Business and Government Action. London: HM Government

Hull Daily Mail. 2011. PM: Hull can be 'world leader' as Siemens move heralds 'new era', Hull Daily Mail, $21^{\text {st }}$ January.

IRENA-GWEC. 2012. 30 Years of Policies for Wind Energy: Lessons from 12 Wind Energy Markets. A joint Report by International Renewable Energy Agency (IRENA) and the Global Wind Energy Council (GWEC). IRENA: Abu Dhabi.

Isaksen, A. 2014. Industrial development in thin regions: trapped in path extension? Journal of Economic Geography 15:585-600.

Jaeger A. 2013. Overview of German Wind Industry Roots, in Maegaard P., Krenz A. and Palz W. (Eds) Wind Power for the World: The Rise of Modern Wind Energy, pp. 407-41. Taylor \& Francis, Boca Raton/Fl. 
Jay, S. 2010. Built at sea - Marine management and the construction of marine spatial planning, Town Planning Review. 81. 2. 73-191;

Junker, J-C. 2014. A New Start for Europe: My Agenda for Jobs, Growth, Fairness and Democratic Change. Opening Statement in the European Parliament Plenary Session Strasbourg, 22 October 2014.

Karlsen, A. 2018. Framing industrialization of the offshore wind value chain - A discourse approach to an event. Geoforum 88, 148-156.

Karnoe, P. and Garud, R. 2012. Path creation: co-creation of heterogeneous resources in the emergence of the Danish wind turbine cluster. European Planning Studies 20, 733-752.

Kenney, M., von Burg, U. 2001. Paths and regions: the creation and growth of Silicon Valley. In R. Garud and P. Karnøe (eds) Path Dependence and Creation. London: Lawrence Erlbaum, 127-148.

Kern, F, Smith, A, Shaw, C, Raven, R and Verhees, B. 2014. From laggard to leader: explaining offshore wind developments in the UK. Energy Policy, 69. pp. 635-646

Klepper, S. (2007) Disagreements, spinoffs, and the evolution of Detroit as the capital of the U.S. automobile industry, Management Science, vol. 53, no. 4, pp. 616-631.

Latham, M. 2015. Is Scotland's Green Energy Dream Under Threat? The Herald, $14^{\text {th }}$ June. 
Lema, R., Berger, A., Schmitz, H. \& Song, H. 2011. Competition and Cooperation between Europe and China in the Wind Power Sector. IDS Working Papers, 2011, 1-45.

Lema, R. Nordensvärd, J. Urban, F. Lütkenhorst, W. 2014. Innovation paths in wind power: Insights from Denmark and Germany. German Development Institute Discussion Paper; No. 17, German Development Institute: Bonn.

MacKinnon, D. 2012. Beyond strategic coupling: reassessing the firm-region nexus in global production networks. Journal of Economic Geography 12:227-245.

Markard J. and Petersen R. 2009. The offshore trend: Structural changes in the wind power sector, Energy Policy. 37, 3545-56

Martin, R. 2000. Institutional approaches in economic geography in T. Barnes and E. Sheppard (eds) A Companion to Economic Geography, Oxford, Blackwell, pp. 77-94.

Martin, R. 2010. Rethinking path dependence: beyond lock-in to evolution. Economic Geography 86: 1-27

Martin, R. and Sunley, P. 2006. Path dependence and regional economic evolution. Journal of Economic Geography 6: 395-437.

Martin, R. and Sunley, P. 2015. Towards a developmental turn in evolutionary economic geography? Regional Studies 49:712-732. 
Maskell, P. and Malmberg, A. 1999. The competitiveness of firms and regions:

'ubiquitification' and the importance of localised learning. European Urban and Regional Studies 6: 9-25.

Mayer, M., Libaers, D. and Park, J.H. 2011. The emergence of novel science-related fields: regional or technological patterns? Exploration and exploitation in United Kingdom Nanotechnology. Regional Studies 45, 935-959.

McMichael, P. 2000. World-systems analysis, globalization and incorporated comparison. Journal of World-Systems Research 6:68-99.

Morgan, K. 2013. Path dependence and the state: The politics of novelty in old industrial regions. In Re-framing regional development: Evolution, innovation, transition, ed. P. Cooke, Abingdon, UK: Routledge. 318-340.

Multiconsult. 2012. Offshore Wind Norway. Market and Supply Chain, 2012. Oslo: Innovation Norway.

Multiconsult. 2015. Omsetning og sysselsetting i den norskbaserte fornybarnæringen (ekskl. verdien av energisalg). Oslo: Multiconsult Analyse \& Strategi.

Musgrove. P. 2010. Wind Power. Cambridge University Press. Cambridge.

Nadin, V. \& Stead, D. 2008 European Spatial Planning Systems, Social Models and Learning, disP - The Planning Review, 44:172, 35-47. 
Neffke, F., Henning, M. and Boschma, R. 2011. How do regions diversify over time? Industry relatedness and the development of new growth paths in regions. Economic Geography 87: 237-265.

Nolte N. (2010) Nutzungsansprüche und Raumordnung auf dem Meer, Hansa Int Marit J 147, 79-83.

Normann, H.E. 2015. The role of politics in sustainable transitions: The rise and decline of offshore wind in Norway. Environmental Innovation and Societal Transitions 15:180-193.

NOU 1998: 11. Energi- og kraftbalansen mot 2020.

NVE. 2012. Havvind - Strategisk konsekvensutredning Oslo: Norges vassdrags- og energidirektorat.

Oelker J. 2005. Windgesichter: Aufbruch der Windenergie in Deutschland. SonnenbuchVerlag, Dresden.

OWIC. 2014. The UK Offshore Wind Supply Chain: A Review of Opportunities and Barriers. Offshore Wind Industry Council (OWIC): London.

O'Sullivan M., Edler D., Bickel P., Lehr U., Peter F. and Sakowski F. 2014. Bruttobeschäftigung durch erneuerbare Energien in Deutschland im Jahr 2013 -eine erste Abschätzung-, p. 20p. Bundesministerium für Wirtschaft und Technologie. 
Painter, J. and Goodwin, M. (1995) Local governance and concrete research: investigating the uneven development of regulation. Economy and Society 24, 334-356.

Peck, J. and Theodore, N. 2007. Variegated capitalism', Progress in Human Geography, 31(6), pp. 731-772

Pike A, Marlow D, McCarthy A, O'Brien P, Tomaney J. 2015. Local institutions and local economic development: the Local Enterprise Partnerships in England, 2010-. Cambridge Journal of Regions, Economy and Society, 8(2), 185-204.

Pike, A. Mackinnon, D, Cumbers, A., Dawley, S. and McMaster, R. 2016. Doing evolution in Economic Geography. Economic Geography 96:123-144.

Portman M. E., Duff J. A., Köppel J., Reisert J. and Higgins M. E. 2009. Offshore wind energy development in the exclusive economic zone: Legal and policy supports and impediments in Germany and the US, Energy Policy, 37, 3596-607.

PWC (2012) Volle Kraft aus Hochseewind, Pricewaterhouse Coopers. Hamburg.

Redpoint Energy. 2012. UK Offshore Wind Market Study - Final Report. A report by Redpoint Energy Limited in association with GL Garrad Hassan on behalf of The Crown Estate. London: The Crown Estate

Reve, T. and A. Sasson. 2012. Et kunnskapsbasert Norge. Oslo: Universitetsforlaget. 
REN21. 2017. Renewables 2017: Global Status Report. Renewable Energy Policy Network for the $21^{\text {st }}$ Century (REN21), REN21; Paris

Renewable UK. 2014. Wind Energy in the UK. State of the Industry Report 2014. Renewable UK: London.

Rusten, G. 2013. The hydropower industry: Technology, regulations and regional effects. In Norway: Nature, Industry and Society, ed. G. Rusten; K. Potthoff; and L. Sangolt, 99-116. Bergen: Fagbokforlaget.

Sadler, D. 2001. The political economy and regional implications of energy policy in Britain in the 1990s Environment and Planning C: Government and Policy 19, 3-28

Sæther, B., Isaksen, A., \& Karlsen, A. (2011). Innovation by co-evolution in natural resource industries: The Norwegian experience. Geoforum, 42(3), 373-381

Schmidt, V. (2005) Democracy in Europe: the impact of European integration. Perspectives in Politics 32, 526-554.

Scott, A. 1988. 'Flexible production systems and regional development: the rise of new industrial spaces in Europe and North America', International Journal of Urban and Regional Research, 12, 171-86 
Schroder, M and Voelzkow, H. 2016. Varieties of regulation: how to combine sectoral, regional and national levels. Regional Studies 50, 7-19.

Scottish Government. 2009. Renewables Action Plan. The Scottish Government, Edinburgh.

Simmie, J. 2012. Path dependence and new technological path creation in the Danish wind power industry. European Planning Studies 20:753-72.

Simmie, J., Martin, R., Carpenter, J., and Chadwick, A. 2008. History Matters: Path Dependence and Innovation in British City Regions. London: National Endowment for Science, Technology and the Arts.

Simmie, J., Sternberg, R., Carpenter, J., 2014. New technological path creation: evidence from the British and German wind energy industries. Journal of Evolutionary Economics 24 (4), 875-904.

Sommer P. (2015) Die Entwicklung der Windenergie: Onshore versus Offshore. Franz Steiner Verlag, Hamburg.

Smith, A. 2015. The state, institutional frameworks and the dynamics of capital in global production networks. Progress in Human Geography 39:290-315.

Smith, A. and Raven, R. 2012. What is protective space? Reconsidering niches in transitions to sustainability. Research Policy 41:1025-1036. 
Solli, J.r. 2010. Where the eagles dare? Enacting resistance to wind farms through hybrid collectives. Environmental Politics 19:45-60.

Steen, M. 2016. Reconsidering path creation in economic geography: aspects of agency, temporality and methods, European Planning Studies, 24:9, 1605-1622,

Steen, M. and G.H. Hansen. 2014. Same Sea, Different Ponds: Cross-Sectorial Knowledge Spillovers in the North Sea. European Planning Studies 22:2030-2049.

Steen, M. \& Hansen, G.H (2018): Barriers to Path Creation: The Case of Offshore Wind Power in Norway, Economic Geography, DOI: 10.1080/00130095.2017.1416953

Steen, M. and A. Karlsen. 2014. Path creation in a single-industry town: The case of Verdal and Windcluster Mid-Norway. Norsk Geografisk Tidsskrift - Norwegian Journal of Geography 68:133-143.

Storper, M. and Walker, R. (1989) The Capitalist Imperative: Territory, Technology and Industrial Growth. Oxford: Blackwell.

Tanner, A.N. 2014. Regional branching reconsidered: emergence of the fuel cell industry in European regions. Economic Geography 90:403-427.

Tellmann, S.M. 2012. The constrained influence of discourses: the case of Norwegian climate policy. Environmental Politics 21:734-752. 
Toke, D. 2011. 'The UK offshore wind power programme: A sea-change in UK energy policy? 'Energy Policy 39, 2, pp. 526-534

Toke, D. and Lauber, V. (2007) Anglo-Saxon and German approaches to neoliberalism and environmental policy: the case of financing renewable energy. Geoforum 38, 677-687.

Trippl, M. and Todtling, F. 2007. Developing biotechnology clusters in non-high technology regions - the case of Austria. Industry and Innovation 14: 47-67.

Trippl, M., Grillitsch, M. and Isaksen, A. 2017. Exogenous sources of regional industrial change: Attraction and absorption of non-local knowledge for new path development. Progress in Human Geography Online First. DOI: 10.1177/0309132517700982.

Weaver, T. and M. Steen. 2013. Utviklingstrekk i den norske energiindustrien. Trondheim: CenSES/NTNU

Wicken, O. 2011. Marked som begrensning for ny kraft. In Energirikdommens paradokser, ed. J. Hanson; S. Kasa; and O. Wicken, 72-81. Oslo: Universitetsforlaget.

Wind Europe. 2016. Making Transition Work. Wind Europe: Brussels

World Bank (2016) Port Reform Toolkit: Alternative Port Management Structures and Ownership Models. Module 3. Washington, DC: World Bank. 
Wüstenhagen R. and Bilharz M. 2006. Green energy market development in Germany: effective public policy and emerging customer demand, Energy Policy 34, 1681-96.

Yeung, H.W-C. 2009. Transnational corporations, global production networks and urban and regional development: a geographer's perspective on Multinational Enterprises and the Global Economy, Growth and Change 40: 197-226.

Yeung, H.W-C. 2014. 'Governing the market in a globalizing era: developmental states, global production networks, and inter-firm dynamics in East Asia', Review of International Political Economy, 21.1. pp. 70-101.

Yeung, H.W-C and Coe, N. M. 2015. Towards a dynamic theory of global production networks. Economic Geography 91:29-58.

Zhu, S., He, C. and Zhou, Y. 2017. How to jump further and catch up? Path-breaking in an uneven industry space. Journal of Economic Geography Online first.

Doi:10.1093/jeg/lbw047 